\title{
HYDROGEOLOGY AND GEOCHEMISTRY OF ACID MINE \\ DRAINAGE IN GROUND WATER IN THE VICINITY OF \\ PENN MINE AND CAMANCHE RESERVOIR, CALAVERAS \\ COUNTY, CALIFORNIA: FIRST-YEAR SUMMARY
}

By Scott N. Hamlin and Charles N. Alpers

U.S. GEOLOGICAL SURVEY

Water-Resources Investigations Report 94-4040

Prepared in cooperation with the

CALIFORNIA STATE WATER RESOURCES CONTROL BOARD and the EAST BAY MUNICIPAL UTILITY DISTRICT

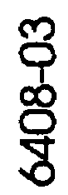




\title{
U.S. DEPARTMENT OF THE INTERIOR BRUCE BABBITT, Secretary
}

\author{
U.S. GEOLOGICAL SURVEY \\ Gordon P. Eaton, Director
}

For sale by the U.S. Geological Survey

Earth Science Information Center

Open-File Reports Section

Box 25286, MS 517

Denver Federal Center

Denver, CO 80225

For additional information write to:

District Chief

U.S. Geological Survey

Federal Building, Room W-2233

2800 Cottage Way

Sacramento, CA 95825 


\section{CONTENTS}

Abstract 1

Introduction 2

Background 2

Purpose and scope 5

Study methods 6

Drilling and well construction 6

Geophysical logging and flowmeter tests 6

Identification of fracture zones 7

Inflatable-packer methodology 8

Ground-water sampling and analysis 8

Water-level measurements 9

Hydrogeology 9

Geology and mineralogy

Geologic structure 9

Hydraulic characteristics of fractured bedrock 11

Water levels 15

Geochemistry 16

Results of sampling 16

Generation of acid mine drainage 20

Distribution of acid mine drainage 22

Geochemical correlations 26

Flow rate of contaminated ground water 29

Metal loading to Camanche Reservoir 29

Summary $\mathbf{3 0}$

References 31

Appendix 1. Geophysical logs from U.S. Geological Survey monitoring wells GS-1 through GS-8 at Penn Mine site 33

Appendix 2. Flowmeter data from U.S. Geological Survey monitoring wells GS-1 through GS-8 at Penn Mine site 41

Appendix 3. Purging-log data for U.S. Geological Survey monitoring wells GS-1 through GS-8 at Penn Mine site 43

Appendix 4. Hydraulic test data from U.S. Geological Survey monitoring wells GS-1 through GS-8 at Penn Mine site 44

\section{FIGURES}

1-3. Maps showing:

1. Location of Penn Mine and Camanche Reservoir in Foothills copper-zinc belt of California 3

2. Penn Mine site and location of unlined wastewater impoundments 4

3. Location of monitoring wells, geologic section lines, and surficial geology 7

4. Geologic section $A-A^{\prime}$ and water levels constructed using data from Camanche Reservoir, wells GS-3 and GS-8, and Mine Run Reservoir 10

5. Map showing subsurface altitude of the metavolcanic-slate contact $\mathbf{1 1}$

6. Hydrograph showing fluctuations in water levels in Camanche Reservoir, Mine Run Reservoir, and in wells at the Penn Mine 14

7. Map showing water-levels in the metavolcanic unit, August 199216 
8,9. Geologic section $B-B^{\prime}$ showing:

8. Distribution of sulfate with depth at the Penn Mine, April 199223

9. Distribution of chloride with depth at the Penn Mine, April 199224

10. Map showing distribution of sulfate in ground water at the Penn Mine, April 199225

11. Graph showing variation of sulfate concentration with $\mathrm{pH}$ in ground water from the Penn Mine, April 199225

12. Maps showing distribution of $\mathrm{pH}$ in ground water at the Penn Mine, April and December 199226

13. Graph showing stable-isotopic composition of ground water and Mine Run Reservoir at the Penn Mine, April and December 199227

14. Map showing distribution of delta oxygen-18 in ground water at the Penn Mine, April 199227 15-17. Graphs showing:

15. Variation of iron with sulfate concentrations in ground water from the Penn Mine, April 199228

16. Plot of $\log \left(\mathrm{Fe}^{3+}\right.$ activity) and $\mathrm{pH}$ with goethite and hydrous ferric oxide equilibrium values for ground water from the Penn Mine, April 199228

17. Plot of $\log \left(\mathrm{Al}^{3+}\right.$ activity) and $\mathrm{pH}$ with gibbsite equilibrium values for ground water from the Penn Mine, April 199229

\section{TABLES}

1. Estimates of transmissivity and hydraulic conductivity at the Penn Mine, April 199212

2. Altitude of water levels for U.S. Geological Survey monitoring wells at the Penn Mine, December 1991 to August 199213

3. Water-quality data for Mine Run Reservoir and wells at the Penn Mine 17

4. Estimates of ground-water flow and metal loading to Camanche Reservoir $\mathbf{3 0}$

\section{CONVERSION FACTORS, WATER-QUALITY INFORMATION, VERTICAL DATUM, AND WELL- NUMBERING SYSTEM}

\section{Conversion Factors}

\begin{tabular}{rll}
\hline Multiply & By & To obtain \\
\hline acre & 0.4047 & hectare \\
acre & 4,047 & square meter \\
cubic foot per day $\left(\mathrm{ft}^{3} / \mathrm{d}\right)$ & 0.02832 & cubic meter per day \\
cubic foot per second $\left(\mathrm{ft}^{3} / \mathrm{s}\right)$ & 0.02832 & cubic meter per second \\
foot $(\mathrm{ft})$ & 0.3048 & meter \\
foot per day $(\mathrm{ft} / \mathrm{d})$ & 0.3048 & meter per day \\
foot per minute $(\mathrm{ft} / \mathrm{min})$ & 0.3048 & meter per minute \\
foot squared per day $\left(\mathrm{ft}^{2} / \mathrm{d}\right)$ & 0.0929 & meter squared per day \\
gallon per minute $(\mathrm{gal} / \mathrm{min})$ & 0.06308 & liter per second \\
gallon per year $(\mathrm{gal} / \mathrm{yr})$ & 0.003785 & cubic meter per year \\
mile $(\mathrm{mi})$ & 1.609 & kilometer \\
pound, avoirdupois $(\mathrm{lb})$ & 0.4536 & kilogram \\
square foot $\left(\mathrm{ft}^{2}\right)$ & 0.09290 & square meter
\end{tabular}

Temperature is given in degrees Celsius $\left({ }^{\circ} \mathrm{C}\right)$, which can be converted to degrees Fahrenheit $\left({ }^{\circ} \mathrm{F}\right)$ by the following equation:

$$
{ }^{\circ} \mathrm{F}=1.8\left({ }^{\circ} \mathrm{C}\right)+32 \text {. }
$$




\section{Water-Quality Information}

Chemical concentrations in water are given in milligrams per liter $(\mathrm{mg} / \mathrm{L})$ or micrograms per liter $(\mu \mathrm{g} / \mathrm{L})$. Milligrams per liter is a unit expressing the solute per unit volume (liter) of water. One thousand micrograms per liter is equivalent to 1 milligram per liter. For concentrations less than about $7,000 \mathrm{mg} / \mathrm{L}$, milligrams per liter is equivalent to "parts per million," and micrograms per liter is equivalent to "parts per billion."

\section{Vertical Datum}

Sea level: In this report, "sea level" refers to the National Geodetic Vertical Datum of 1929-a geodetic datum derived from a general adjustment of the first-order level nets of the United States and Canada, formerly called Sea Level Datum of 1929.

\section{Well-Numbering System}

Wells are identified and numbered according to their location in the rectangular system for the subdivision of public lands. Identification consists of the township number, north or south; the range number, east or west; and the section number. Each section is divided into sixteen 40 -acre tracts lettered consecutively (except $I$ and $O$ ), beginning with " $\mathrm{A}$ " in the northeast corner of the section and progressing in a sinusoidal manner to " $\mathrm{R}$ " in the southeast corner. Within the 40-acre tract, wells are sequentially numbered in the order they are inventoried. The final letter refers to the base line and meridian. In California, there are three base lines and meridians; Humboldt $(\mathrm{H})$, Mount Diablo (M), and San Bernardino (S). All wells in the study area are referenced to the Mount Diablo base line and meridian (M). Well numbers consist of 11 characters and follow the format $004 \mathrm{~N} 10 \mathrm{E} 4 \mathrm{G} 02$. In this report, well numbers are abbreviated and written $4 \mathrm{~N} / 10 \mathrm{E}-4 \mathrm{G} 2$. Wells in the same township and range are referred to only by their section designation, 4G2. The following diagram shows how the number for well $4 \mathrm{~N} / 10 \mathrm{E}-4 \mathrm{G} 2$ is derived.

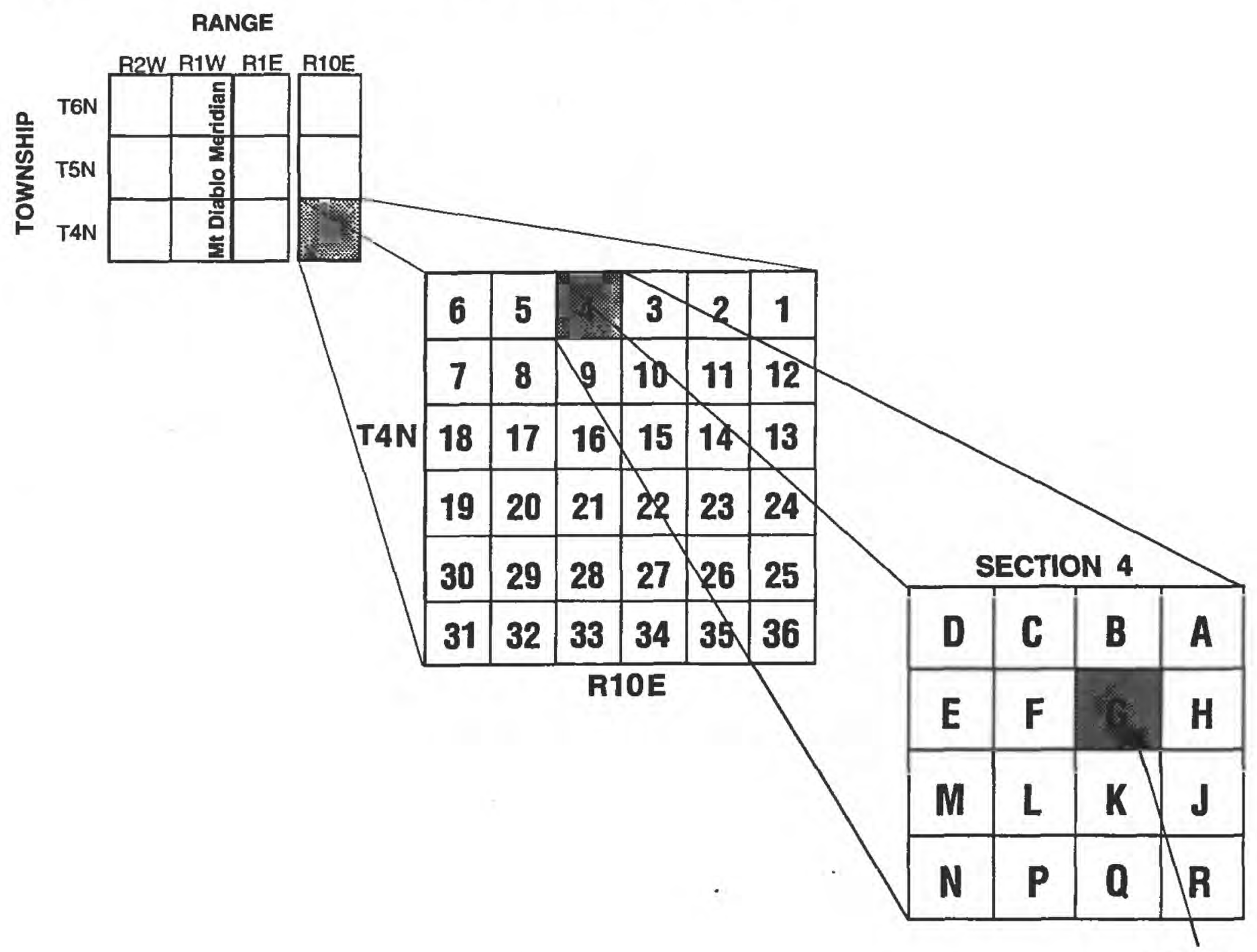




\title{
HYDROGEOLOGY AND GEOCHEMISTRY OF ACID MINE
}

\section{DRAINAGE IN GROUND WATER IN THE VICINITY OF}

\section{PENN MINE AND CAMANCHE RESERVOIR, CALAVERAS COUNTY, CALIFORNIA: FIRST-YEAR SUMMARY}

\author{
By Scott N. Hamlin and Charles N. Alpers
}

\section{Abstract}

Acid drainage from the Penn Mine in Calaveras County, California, has caused contamination of ground water between Mine Run Dam and Camanche Reservoir. The Penn Mine was first developed in the 1860's primarily for copper and later produced lesser amounts of zinc, lead, silver, and gold from steeply dipping massive sulfide lenses in metamorphic rocks. Surface disposal of sulfidic waste rock and tailings from mine operations has produced acidic drainage with $\mathrm{pH}$ values between 2.3 and 2.7 and elevated concentrations of sulfate and metals, including copper, zinc, cadmium, iron, and aluminum. During the mine's operation and after its subsequent abandonment in the late 1950's, acid mine drainage flowed down Mine Run into the Mokelumne River. Construction of Camanche Dam in 1963 flooded part of the Mokelumne River adjacent to Penn Mine. Surface-water diversions and unlined impoundments were constructed at Penn Mine in 1979 to reduce runoff from the mine, collect contaminated surface water, and enhance evaporation. Some of the contaminated surface water infiltrates the ground water and flows toward Camanche Reservoir.

Ground-water flow in the study area is controlled by the local hydraulic gradient and the hydraulic characteristics of two principal rock types, a Jurassic metavolcanic unit and the underlying Salt Spring slate. The hydraulic gradient is west from Mine Run impoundment toward Camanche Reservoir. The median hydraulic conductivity was about 10 to 50 times higher in the metavolcanic rock $(0.1$ foot per day) than in the slate ( 0.002 to 0.01 foot per day); most flow occurs in the metavolcanic rock where hydraulic conductivity is as high as 50 feet per day in two locations. The contact between the two rock units is a fault plane that strikes $\mathrm{N} 20^{\circ} \mathrm{W}$, dips $20^{\circ} \mathrm{NE}$, and is a likely conduit for ground-water flow, based on down-hole measurements with a heat-pulse flowmeter.

Analyses of water samples collected during April 1992 provide a comprehensive characterization of ground water below Mine Run Dam at the Penn Mine. Specific conductance of the samples ranged from 1,810 to 18.000 microsiemens per centimeter. $\mathrm{pH}$ values of sampled ground water ranged from 3.7 to 7.8. Dissolved constituents in ground water ranged from less than $\mathbf{0 . 0 1 0}$ to 86 milligrams per liter for copper, from less than 0.010 to 240 milligrams per liter for iron, from less than 0.01 to 250 milligrams per liter for aluminum, and from 0.020 to 600 milligrams per liter for zinc. A contaminated ground-water plume appears to originate in the metavolcanic unit along the north abutment of Mine Run Dam. The plume is characterized by low $\mathrm{pH}$, high concentrations of sulfate and dissolved metals, and enrichment of the heavy stable isotopes of hydrogen and oxygen. Dissolved iron and sulfate correlate positively, suggesting pyrite as the probable source of these elements. The concentrations of some dissolved constituents apparently are controlled by equilib- 
rium with solid mineral phases. Poorly crystalline hydrous ferric oxide and microcrystalline gibbsite are close to saturation in ground water with $\mathrm{pH}$ values between 4 and 7.8 and probably control the solubility of $\mathrm{Fe}^{3+}$ and $\mathrm{Al}^{3+}$, respectively.

Using a range of bulk hydraulic conductivity values for the metavolcanic unit from the median value ( 0.1 foot per day) to the highest values ( 50 feet per day), together with a representative cross-sectional area (3,000 square feet) for the contaminated ground-water plume and a hydraulic gradient of 0.14 from August 1992, the following range in ground-water flow rates is estimated by Darcy's law: 42 to 21,000 cubic feet per day, or $10^{5}$ to $5 \times 10^{7}$ gallons per year. Multiplying this estimated range in ground-water flow by representative metal concentrations from the contaminated plume gives the following estimates for annual metal transport to Camanche Reservoir by ground water: 86 to 42,000 pounds of copper; 310 to 150,000 pounds of zinc; and 1.5 to 750 pounds of cadmium. These crude preliminary estimates may be refined using numerical modeling of flow and transport processes. The high values for metal transport rates are upper bounds and represent worst-case conditions.

\section{INTRODUCTION}

\section{BACKGROUND}

The Penn Mine is an abandoned copper-zinc mine in the Foothills copper-zinc belt in northwestern Calaveras County, California (Peterson, 1985) (fig. 1). The mine property encompasses about 140 acres (Finlayson and Rectenwald, 1978) in the Mine Run drainage basin, an intermittent tributary to Camanche Reservoir. Mining activity at Penn Mine lasted from the early 1860's to the late 1950's (Clark and Lydon, 1962). The area has 20 or more shafts, several adits, and numerous open pits and cuts; two smelters and several mills operated at the site (Clark and Lydon, 1962). About $10.5 \mathrm{mi}$ of underground workings were excavated to a depth of $3,300 \mathrm{ft}$ (Heyl and others, 1948). Several acres of mill tailings and unmilled waste rock are exposed on the surface (Bond, 1988); slag from the smelters was dumped in a 1,500foot-long area immediately adjacent to the former
Mokelumne River channel (Finlayson and Rectenwald, 1978).

Historically, contaminated surface runoff from the Penn Mine flowed directly into the Mokelumne River (Shaw and Towers, 1937; Dunham, 1961). Completion of Pardee Dam in 1929 on the river about $3 \mathrm{mi}$ upstream from the mine decreased the streamflow available for diluting the contaminated runoff. Completion of Camanche Dam in 1963 resulted in flooding part of the Mokelumne River basin from about $9 \mathrm{mi}$ downstream of Penn Mine to approximately $0.5 \mathrm{mi}$ upstream. The spillway elevation of Camanche Dam is $236 \mathrm{ft}$ above sea level. Consequently, slag at the mine is partly flooded when the reservoir pool is higher than about $200 \mathrm{ft}$ above sea level (Finlayson and Rectenwald, 1978).

Fish mortality in the Mokelumne River owing to contamination from the Penn Mine was recorded as early as 1937 (Shaw and Towers, 1937) and continued periodically until the beginning of the construction of Camanche Dam in 1960 (Dunham, 1961; Finlayson and Rectenwald, 1978). Fish mortality at the salmon and steelhead hatchery, completed just downstream from Camanche Dam in 1964, was documented in 1967, 1973, 1977, 1987, and 1989 (Bond, 1988; S.R. Bond, California Regional Water Quality Control Board--Central Valley Region, written commun., 1989), although no surface-water discharges were emitted from Penn Mine from June 1986 to January 1993 (T. Pinkos, California Regional Water Quality Control Board-Central Valley Region, written commun., 1993).

Several diversion channels were constructed in 1978 at the Penn Mine site to divert unpolluted water from upstream areas on Hinckley and Mine Runs to Camanche Reservoir (T. Pinkos, California Regional Water Quality Control Board--Central Valley Region, written commun., 1978, 1979). Seven unlined impoundments were built in place of two or more existing impoundments to capture contaminated runoff from the site (fig. 2). The Mine Run Dam, constructed from nonreactive earth materials with a clay core (California Regional Water Quality Control Board--Central Valley Region, written commun., 1979), was built by the East Bay Municipal Utility District (herein referred to as the Utility District) on their property between the mine and Camanche Reservoir. The remaining dams or dikes were constructed from available sulfide-bearing waste rock and mill tailings; the impoundments were unlined. They were constructed on property belonging to New 


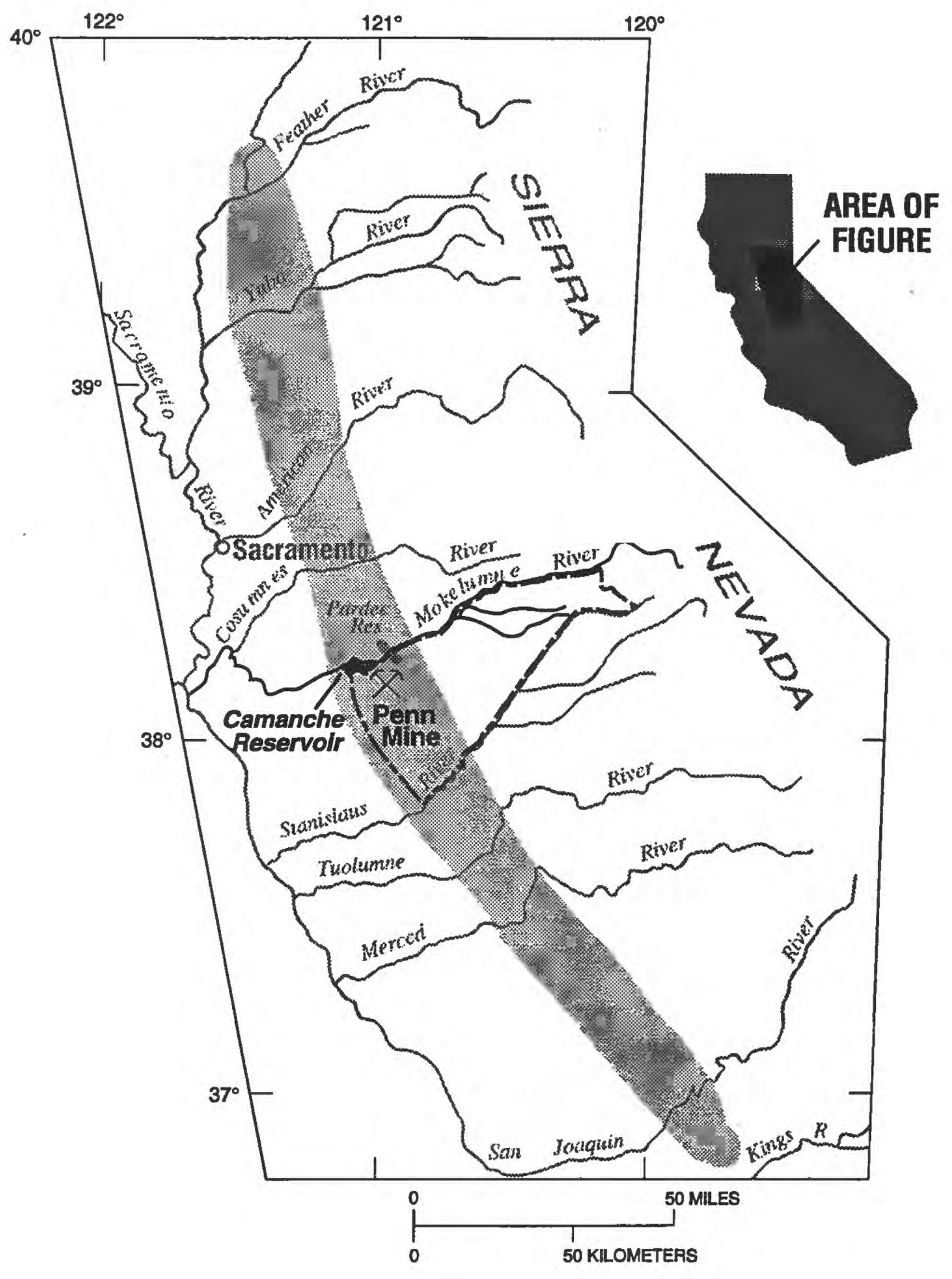

EXPLANATION

Copper-zinc belt

- - Outline of Calaveras County

Figure 1. Location of Penn Mine and Camanche Reservoir in Foothills copper-zinc belt of California (after Peterson, 1985). 


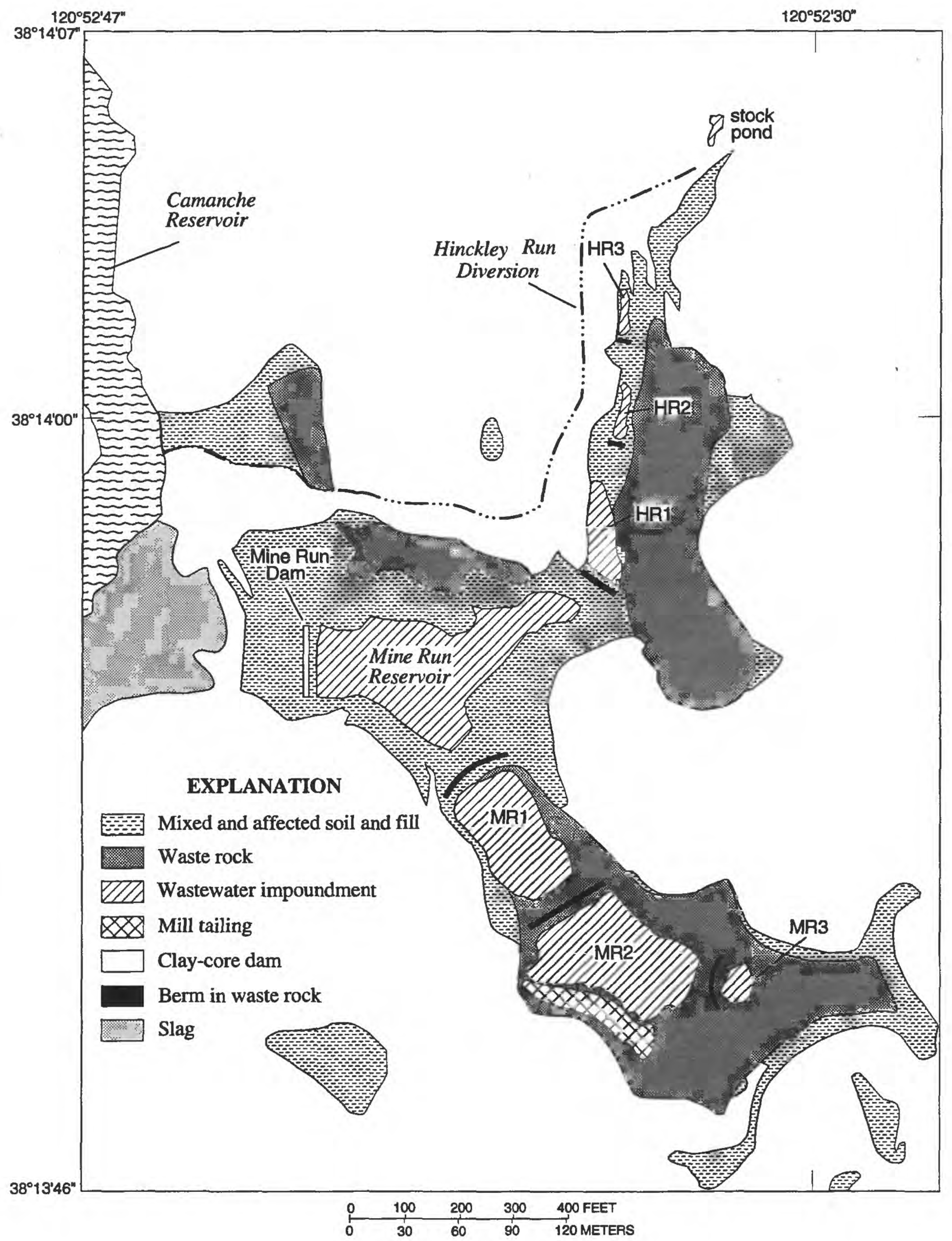

Figure 2. Penn Mine site and location of unlined wastewater impoundments. (Distribution of mixed and affected soii, mixed fill, waste rock, and tailings modified from Davy Environmental, 1993). 
Penn Mines, Inc., by the California Regional Water Quality Control Board--Central Valley Region (herein referred to as the Control Board) (California Regional Water Quality Control Board--Central Valley Region, written commun., 1978, 1979). The system, designed to enhance evaporation of contaminated water by pumping the water from Mine Run Reservoir to upstream ponds on Mine Run, was operated jointly by the Utility District and the Control Board between 1979 and 1992 (T. Pinkos, California Regional Water Quality Control Board--Central Valley Region, written commun., 1993).

Recirculation of water in the ponds has increased the amount of evaporation and the contact time of acid drainage with the reactive waste rock and tailings (Bond, 1988). As much as 95 percent of the sulfide minerals in waste rock has been oxidized (Davy Environmental, 1993). Because the impoundments are unlined, some of the water in the lowermost impoundment can infiltrate the underlying aquifer in fractured metamorphic rock. In addition, controlled releases of surface water from Mine Run Reservoir to Camanche Reservoir were made during wet periods in 1979 through 1984 and in 1986 at rates estimated between 0.1 and $0.7 \mathrm{ft}^{3} / \mathrm{s}$; uncontrolled releases estimated as high as $2.7 \mathrm{ft}^{3} / \mathrm{s}$ occurred during extremely wet periods in 1983 and 1986 (Bond, 1988). Surface-water releases did not take place between June 1986 and January 1993 during a time of prolonged drought. However, a relatively small amount of surface water discharged during February-March 1993 after Mine Run Reservoir had been treated with hydrated lime $\left[\mathrm{Ca}(\mathrm{OH})_{2}\right]$ to attain a $\mathrm{pH}$ value of greater than 7.0 (Richard Sykes, East Bay Municipal Utility District, oral commun., 1993).

Concentrations of metals and sulfate in the wastewater ponds fluctuate seasonally, with maximum concentrations in the late summer/early autumn (August to October) possibly from evaporative concentration (Davy Environmental, 1993). Data collected since 1987 do not indicate any clear longterm trends in the concentrations from year to year (Davy Environmental, 1993). Oxidative dissolution of metal sulfides has continued unabated on the site, however, so metals released to solution since 1987 have either accumulated in sediment on the bottoms of the ponds or have been transported out of the ponds into ground water.
To quantify the flux of metals leaving the unlined impoundments, information needed to define the extent of contamination and develop remediation alternatives, the U.S. Geological Survey (USGS), in cooperation with the Control Board and the Utility District, investigated the chemical composition and movement of ground water at Penn Mine from December 1991 to December 1992. The specific objectives of the investigation by the USGS are: (1) to determine the quantity and quality of ground water flowing into Camanche Reservoir from the Penn Mine area, (2) to quantify ground-water transport of metals, sulfate, and acidity between Mine Run and Camanche Reservoirs, (3) to collect hydrologic and chemical data that will contribute to an understanding of the water balance in the Mine Run drainage basin, and (4) to provide technical information to the cooperating State and regional agencies (the Utility District and the Control Board) that will assist in formulating remediation plans for Penn Mine. Accomplishment of these objectives will facilitate the development of effective pollution abatement measures for the site.

\section{PURPOSE AND SCOPE}

This report presents initial findings from the first year of the U.S. Geological Survey study to characterize the distribution of metals, sulfate, and acidity in ground water flowing through the fracturedrock aquifer between Mine Run Dam and Camanche Reservoir (fig. 2). The report describes the geologic structure, ground-water movement, and the distribution of acidic mine drainage in the ground-water system. Geologic, hydrologic, and water-quality data were collected during 1991-92 from eight wells drilled in this area. Lithologic data from drill cuttings and geologic logs show the location of the contact between the two major rock types in the area, greenschist-grade metavolcanic rock (Gopher Ridge volcanics) and slate (Salt Spring slate). Downhole acoustic-televiewer logs show the orientation and location of fractures and the lithologic contact. Downhole tests with a heat-pulse flowmeter have determined the location of fractures that conduct ground-water flow. Composite and depth-specific water samples were collected three times during the study period. Water-quality data were compiled and analyzed to determine chemical relations and mineral equilibria. 


\section{STUDY METHODS}

\section{DRILLING AND WELL CONSTRUCTION}

Eight boreholes were drilled during November $4-15,1991$. Locations of the USGS monitoring wells GS-1 through GS-8 are shown in figure 3. A 9.5-inch-diameter rotary bit was used to penetrate the overburden (alluvium and slag) and the upper 5 to 8 $\mathrm{ft}$ of underlying bedrock (metavolcanic rock). In most cases, compressed air was sufficient to keep the hole open during rotary drilling, but a foam drilling additive was required at three boreholes to prevent caving. The water used during drilling was spiked with sodium bromide to yield a bromide concentration of about $100 \mathrm{mg} / \mathrm{L}$ (milligrams per liter) to facilitate detection of ground-water contamination during subsequent water-quality sampling. Drill cuttings were monitored continuously, and samples were collected every 5 to $10 \mathrm{ft}$.

Six-inch-diameter polyvinyl chloride (PVC) casing (schedule 40) was set to the depth of the 9.5-inch-diameter holes, which ranged from 20 to 40 $\mathrm{ft}$ below land surface. The bottom $5 \mathrm{ft}$ of the annular space between casing and hole wall was filled with 3/8-inch bentonite pellets followed by hydrated mortar mix. In holes with more than $20 \mathrm{ft}$ of PVC casing, non-sulfide-bearing drill cuttings were used for some of the backfilling of the annular space surrounding the casing. The upper 3 to $4 \mathrm{ft}$ of the annular space was filled with hydrated mortar mix and left to set overnight.

After the mortar mix had set, a 5.5-inch-diameter air-hammer bit was used to drill into the bedrock through the 6-inch casing until the desired depth was reached. All eight boreholes were drilled to a depth of $200 \mathrm{ft}$ below land surface except GS-6, which was drilled to a depth of $400 \mathrm{ft}$ below land surface. The thickness of slag, which covers most of the area west of Mine Run Dam, ranged from 0.5 to $38 \mathrm{ft}$. The contact between metavolcanic rocks and slate was encountered in seven of the holes between depths of 45 and $105 \mathrm{ft}$ below land surface. In hole GS-7, the lithology changed back and forth between slate and metavolcanic rock indicating a disrupted zone, possibly a fault zone or a tightly folded contact. Drilling through the Salt Spring slate unit was extremely fast with the air-hammer bit, averaging more than $2 \mathrm{ft} / \mathrm{min}$. Five of the eight wells drilled "dry," not producing any flowing water. Heat generated from the compressed air during drilling tends to dry out drill cuttings on their path up the hole, so inflows of less than $0.5 \mathrm{gal} / \mathrm{min}$ can result in dry cuttings (J.A. Singer, U.S. Geological Survey, oral commun., 1991). The three "wet" holes (more than $0.5 \mathrm{gal} / \mathrm{min}$ inflow) were GS-5, -7 , and -8 . After drilling, all the holes were left open below the 6-inch casing, except for hole GS-7, which partially caved and was filled with slotted, 3-in-diameter PVC casing to a depth of $50 \mathrm{ft}$ below land surface.

\section{GEOPHYSICAL LOGGING AND FLOWMETER TESTS}

The open boreholes were logged by standard geophysical methods, acoustic televiewer, and heat-pulse flowmeter during November 1991. The standard geophysical logs included natural gamma, fluid temperature, lateral resistivity [single point, 16 and 32 $\mathrm{mm}$ (millimeter)], fluid resistivity, short-normal resistivity, long-normal resistivity, and caliper. The gamma log differentiates the two principal rock types encountered: slate and metavolcanic rock units. The relatively high radioisotope $(\mathrm{K}, \mathrm{U})$ content of the slate gives it a distinctively high gamma response. The gamma logs are provided in appendix 1.

The acoustic televiewer uses high-frequency acoustic energy to produce a $360^{\circ}$ visual record of the borehole surface (Zemanek and others, 1970). It can yield high-resolution information about the location and character of fractures and other openings, as well as provide the strike and dip of individual fractures and groups of fractures. The thickness or aperture of individual fractures also can be estimated from this log. The acoustic televiewer is not subject to the problems of optical clarity and distortion common to some video-camera logs (Paillet and others, 1987; Paillet and Kapucu, 1989).

Downhole flowmeter tests determined intervals of natural or induced flow. The flowmeter consisted of two thermistors, one located above and one below a filament that puts out a tiny heat pulse when triggered (Hess, 1986; Paillet and others, 1987). The velocity of flow in the borehole is inversely proportional to the time it takes the pulse to reach one of the thermistors. Detection of the pulse by the upper or lower thermistor determines whether flow is up or down. An inflatable bladder concentrates the flow through the meter to facilitate the determination of low-flow rates. The flowmeter response is calibrated directly to discharge, rather than using an interim determination of velocity. The lower limit of detection for this method is about $0.02 \mathrm{gal} / \mathrm{min}$ when measured in a 6-inch well (Hess, 1986). Flowmeter tests could not be done in boreholes GS-5 and -7 owing to caving that occurred prior to arrival of the logging equipment. 


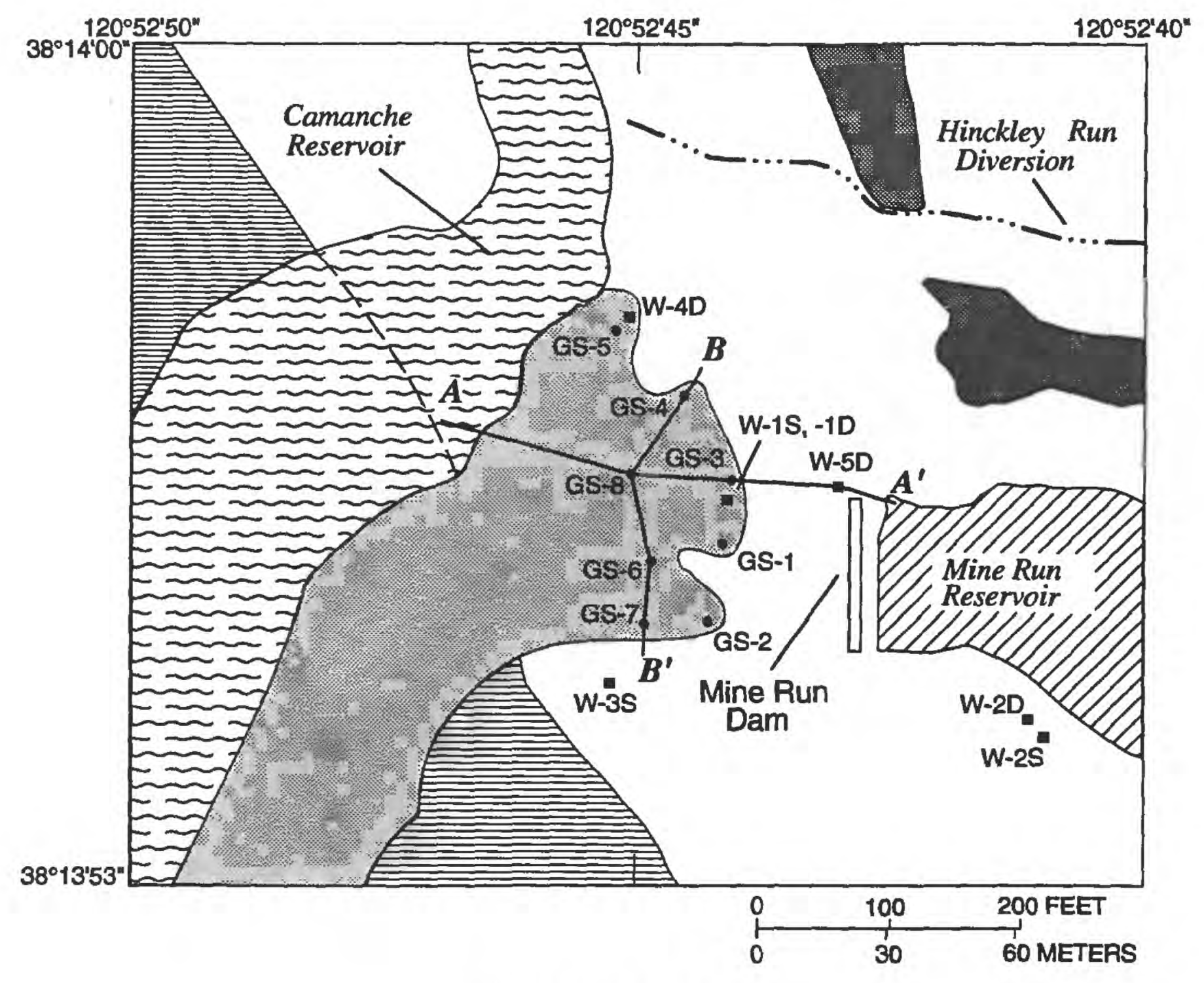

EXPLANATION

\begin{aligned} \hline & Waste rock \\ \hline & Wastewater impoundment \\ \hline & Metavolcanic rock \\ \hline & Slag \\ \hline GS-2 & USGS well and number \\ .W-3S & EBMUD well and number \end{aligned}

Figure 3. Location of monitoring wells, geologic section lines, and surficial geology.

\section{IDENTIFICATION OF FRACTURE ZONES}

In general, an excellent correlation was found between the downhole acoustic televiewer and the caliper logs. Fracture zones indicated by televiewer logs tend to be associated with large-diameter segments of the caliper logs. In several of the holes, the metavolcanic-slate contact is a large-diameter zone, probably a conduit for ground-water flow. Graphical reproductions of the televiewer logs are included in appendix 1.

The flowmeter tests were run in static and injection modes. Results of these tests are included in appendix 2. The flowmeter was lowered into the well in the static mode, and readings were taken at 
several depths. Static tests were completed in boreholes GS-1, $-2,-3,-5$, and -8 . Only one site, well GS-8, yielded conclusive results in the static mode and exhibited downward flow of approximately $1 \mathrm{gal} / \mathrm{min}$ in the depth interval 43 to $60 \mathrm{ft}$ below land surface. Flow was not detected at depths greater than $67 \mathrm{ft}$ below land surface in well GS-8, indicating that flow was leaving the well in a fractured zone between 60 and $67 \mathrm{ft}$ below land surface along the fault contact between metavolcanic rock and slate. Borehole GS-5 yielded evidence of slight downward flow in static mode at a depth of $43 \mathrm{ft}$ below land surface; however, large borehole diameters caused by extensive caving made it difficult to find depths at which flowmeter tests could be made in this well.

\section{INFLATABLE-PACKER METHODOLOGY}

Segments of the bore holes were isolated for additional testing to distinguish flow and chemical characteristics of individual fracture zones. Four inflatable packers were installed in three of the fractured-rock monitoring wells. Double (straddle) packers were installed at one site and single packers were installed at the two remaining sites. Once inflated, the packer virtually eliminates vertical ground-water flow and mixing.

Single packers were installed at sites GS-1 and GS-8. Upper intervals were designated as " $A$ " and lower intervals as "B". The packer at GS-1, set at a depth of $80 \mathrm{ft}$ below land surface, separated two intervals, GS-1A and -1B. The upper interval monitored the metavolcanic unit and metavolcanic-slate contact at a depth of $70 \mathrm{ft}$ below land surface. The lower interval monitored the slate unit exclusively. The packer at GS-8 was set at a depth of $76 \mathrm{ft}$ below land surface. Interval GS-8A monitored the metavolcanic unit and the metavolcanic-slate contact; GS-8B monitored ground water in the slate unit. Two packers (a "straddle" assembly) were installed at site GS-4 at depths of 55 and $80 \mathrm{ft}$ below land surface. The intervals are designated GS-4A, $-4 B$, and $-4 C$ from shallow to deep levels. GS-4A monitored ground water in the upper part of the metavolcanic unit. GS-4B monitored the lower part of the metavolcanic unit and the metavolcanic-slate contact. GS-4C monitored the slate unit exclusively. Hole GS-6 was open from 30 to $400 \mathrm{ft}$ below land surface and monitored both the slate and metavolcanic units. The remaining sites (GS-2, $-3,-5$, and -7) were drilled to a depth of $200 \mathrm{ft}$ below land surface and also monitored ground water from both the slate and metavolcanic units.
The packer assemblies required customization to minimize exposure of metallic parts to ground water, which could compromise water-quality sampling by either dissolution or adsorption of base metals. Custom features in this application were (1) a PVC liner in the central, through-going steel tube, and (2) two through-going, stainless-steel tubes in the upper packer of the two-packer assembly for inflation and water transmission. One of the stainless-steel tubes installed in the upper packer transmitted water from the middle interval; the other tube connected the tubing that carries gas to inflate the lower packer assembly. Exposed parts of the packers were mainly stainless steel and rubber. Some reactive steel parts also were exposed; these were covered with 0.25-millimeter-thick plastic tape. The epoxy paint initially used to protect the steel parts disintegrated in the acidic ground water at the site.

\section{GROUND-WATER SAMPLING AND ANALYSIS}

The wells installed by the USGS were sampled during three periods: January 26-February 1, 1992; April 13-18, 1992; and December 10-22, 1992. Specific conductance, hydrogen-ion activity $(\mathrm{pH})$, temperature, dissolved oxygen, and oxidationreduction potential (Eh) were measured in the field. These properties were determined from samples collected during pumping or bailing. Purging-log data are compiled in appendix 3 . Field properties were measured using a flow-through chamber to prevent aeration of the ground water. After field properties stabilized, water samples were collected and processed using standard methods adopted by the USGS (Wood, 1976). Samples for anion analysis were filtered using $0.10-\mu \mathrm{m}$ (micrometer) membranes. Samples for cation analysis were filtered in a similar manner and acidified with hydrochloric or nitric acid to a $\mathrm{pH}$ of about 1. Samples for nutrient analysis were filtered, preserved with mercuric chloride, and chilled. All samples were submitted to the USGS central laboratory for analysis. Replicate samples processed at four sites were submitted to the Utility District laboratory for comparison.

Laboratory analytical techniques for dissolved constituents are described by Fishman and Friedman (1985). Methods used to determine stable-isotope ratios for hydrogen are described by Coplen and others (1991) and for oxygen by Epstein and Mayeda (1953). Dissolved cadmium, calcium, copper, iron, magnesium, manganese, potassium, sodium, and zinc were determined using atomic absorption spectrometry (AAS) with air aspiration. Lead was determined by 
AAS using a graphite furnace. Aluminum was determined by AAS using a direct-current argon plasma. The anions chloride, fluoride, and sulfate were determined by ion chromatography. Silica and bromide were determined using colorimetric techniques.

\section{WATER-LEVEL MEASUREMENTS}

Water levels were measured and compiled after the installation of inflatable borehole packers. Initial measurements were made with a calibrated steel tape. Concern over contamination of well water and problems with condensation inside the well casing prompted a change to an electric sounder in January 1992. Automated water-level recorders were installed at sites GS-1, $-4,-6$, and -8 . Shaft encoders, in conjunction with float-counterweight mechanisms, were used at wells GS-1A, $-1 \mathrm{~B},-4 \mathrm{~B},-4 \mathrm{C},-6,-8 \mathrm{~A}$, and $-8 \mathrm{~B}$. Because of space limitations, a pressure transducer was used to monitor water levels in well GS-4A. Water-level data were recorded on an hourly basis with datalogger units at each of the four instrumented sites.

Water-level drawdown and recovery data were collected from boreholes during the water-quality sampling in April 1992. Static water levels were measured with an electric sounder prior to pumping or bailing and immediately afterwards during recovery. Because water levels change most rapidly during the period immediately after pumping stops, initial water levels were measured frequently, about once per minute. After about the first $\mathbf{1 0}$ minutes of recovery, the frequency of measurements was reduced to once every 10 minutes, then to hourly, and eventually to daily readings. Because analysis of water-level data collected during aquifer tests uses a log scale for time, measurement frequency generally corresponds to powers of ten $(10,100,1,000, \ldots)$. These data are presented graphically in appendix 4 .

\section{HYDROGEOLOGY}

\section{GEOLOGY AND MINERALOGY}

The study area lies in the western metamorphic belt of the Sierra Nevada (Clark, 1964). Marine sedimentary and volcanic rocks were deposited in the Jurassic period, then buried and metamorphosed during the Cretaceous period (Schweickert, 1981). Rocks in the vicinity of the mine include (1) a Tertiary conglomerate, which unconformably overlies all other units and caps the hills; (2) the Gopher Ridge Volcanics, a metavolcanic complex consisting of one intrusive and five volcanic units; and (3) the metasedimentary Salt Spring slate (Peterson, 1985) (fig. 3). Metavolcanic rocks in the area have weak to intense bedding, schistosity, and cleavage that trend $\mathrm{N} 30^{\circ} \mathrm{W}$ to $\mathrm{N}$ and dip steeply to the northeast or east (Peterson, 1985; Martin, 1988).

Fine-grained white mica, quartz, and hematite are locally abundant near the mineralized zones, owing to hydrothermal alteration that accompanied the sulfide mineralization of Jurassic age. Minerals formed during the greenschist-grade metamorphism include chlorite, epidote, pumpellyite, quartz [in veins up to $10 \mathrm{~cm}$ (centimeter) in width], and additional mica. Schistosity is pervasive in areas with abundant white mica (from hydrothermal alteration) that was recrystallized in parallel orientation during metamorphism in a nonisostatic stress field.

Massive sulfide ore bodies are associated with the intrusive metavolcanic unit and consist primarily of pyrite $\left(\mathrm{FeS}_{2}\right)$, chalcopyrite $\left(\mathrm{CuFeS}_{2}\right)$, and sphalerite [(Zn,Fe,Cd)S] (Peterson, 1985; Martin, 1988). Ore bodies occur as steeply pitching lenses along bedding or foliation planes and range in size from 150 to $1,000 \mathrm{ft}$ along pitch, 100 to $400 \mathrm{ft}$ in breadth, and 4 to $30 \mathrm{ft}$ in width (Heyl and others, 1948). Stringer, disseminated, and vein ores are known to be present, and minor amounts of bornite $\left(\mathrm{Cu}_{5} \mathrm{FeS}_{4}\right)$, tetrahedrite-tennantite $\left[(\mathrm{Cu}, \mathrm{Ag}, \mathrm{Fe}, \mathrm{Zn})_{12}(\mathrm{Sb}, \mathrm{As})_{4} \mathrm{~S}_{13}\right]$, and galena $(\mathrm{PbS})$ have been reported (Peterson, 1985; Martin, 1988). High concentrations of cadmium, arsenic, molybdenum, and antimony also are associated with the ore (Peterson, 1988).

The following minerals have been identified in samples from waste-rock and tailings piles by optical examination and $\mathrm{x}$-ray diffraction methods: bornite, chalcopyrite, pyrite, sphalerite, galena, brochantite $\left[\mathrm{Cu}_{4}\left(\mathrm{SO}_{4}\right)(\mathrm{OH})_{6}\right]$, covellite (CuS), halotrichite-pickeringite $\left[\left(\mathrm{Fe}^{\mathrm{II}}, \mathrm{Mg}\right) \quad \mathrm{Al}_{2}\left(\mathrm{SO}_{4}\right)_{4} \cdot 22 \mathrm{H}_{2} \mathrm{O}\right]$, and copiapite $\left[\mathrm{Fe}^{\mathrm{Il}} \mathrm{Fe}^{\mathrm{III}}{ }_{4}\left(\mathrm{SO}_{4}\right)_{6}(\mathrm{OH})_{2} \cdot 2 \mathrm{OH}_{2} \mathrm{O}\right]$.

\section{GEOLOGIC STRUCTURE}

Geologic features that control the movement and distribution of ground water at the Penn Mine include fractures in the bedrock, fault planes, and the contact between the two major rock types in the area. Bedrock fractures that transmit ground water are chiefly near the base of the metavolcanic rock unit. The metavolcanic-slate contact dips about $20^{\circ} \mathrm{NE}$ and was encountered at depths between 45 and $105 \mathrm{ft}$ below land surface in boreholes. The underlying slate unit has been identified as the Salt Spring slate by Peterson (1985) and is significantly less permeable 
than the overlying metavolcanic rock. The metavolcanic-slate contact may be controlled by the Campo Seco Fault (Heyl and others, 1948). This fault produces an offset in the lithologic contact of about $1,000 \mathrm{ft}$ and extends into the mine workings. However, the slate unit is not present in the mine workings, which were excavated exclusively in greenschist-grade metavolcanic rocks. The relatively impermeable slate below the contact is likely to form a barrier to downward movement of ground water from the metavolcanic unit, causing the contact zone to act as a conduit that transmits ground water along its strike, which is generally $\mathrm{N} 20^{\circ} \mathrm{W}$.

Geologic sections (locations indicated in fig. 3) were constructed using lithologic data to show the orientation of the metavolcanic-slate contact. Figure 4 shows section $A-A^{\prime}$, oriented roughly east-west.
Water-levels from August 1992 also are shown. This section shows apparent discontinuities in the slope of the geologic contact. Some of the discontinuities are explained by the presence of a second fault (or tightly folded zone) oriented perpendicular to the contact and striking roughly $N 70^{\circ} \mathrm{E}$. This fault may have been intersected by borehole GS-7: During drilling of GS-7, cuttings alternated between slate and metavolcanic rock and the hole continually caved in, suggesting the presence of fault gouge. This hypothesized fault is shown in the contour map of the elevation of the top of the slate unit (fig. 5). In general, fault surfaces form a barrier to perpendicular ground-water flow, whereas flow along the fault surface is normally enhanced. Davy Environmental (1993) also reported northeast-trending faults in other areas of the Penn Mine. Detailed mapping in progress by USGS of outcrops near boreholes GS-3,
West

$\boldsymbol{A}$

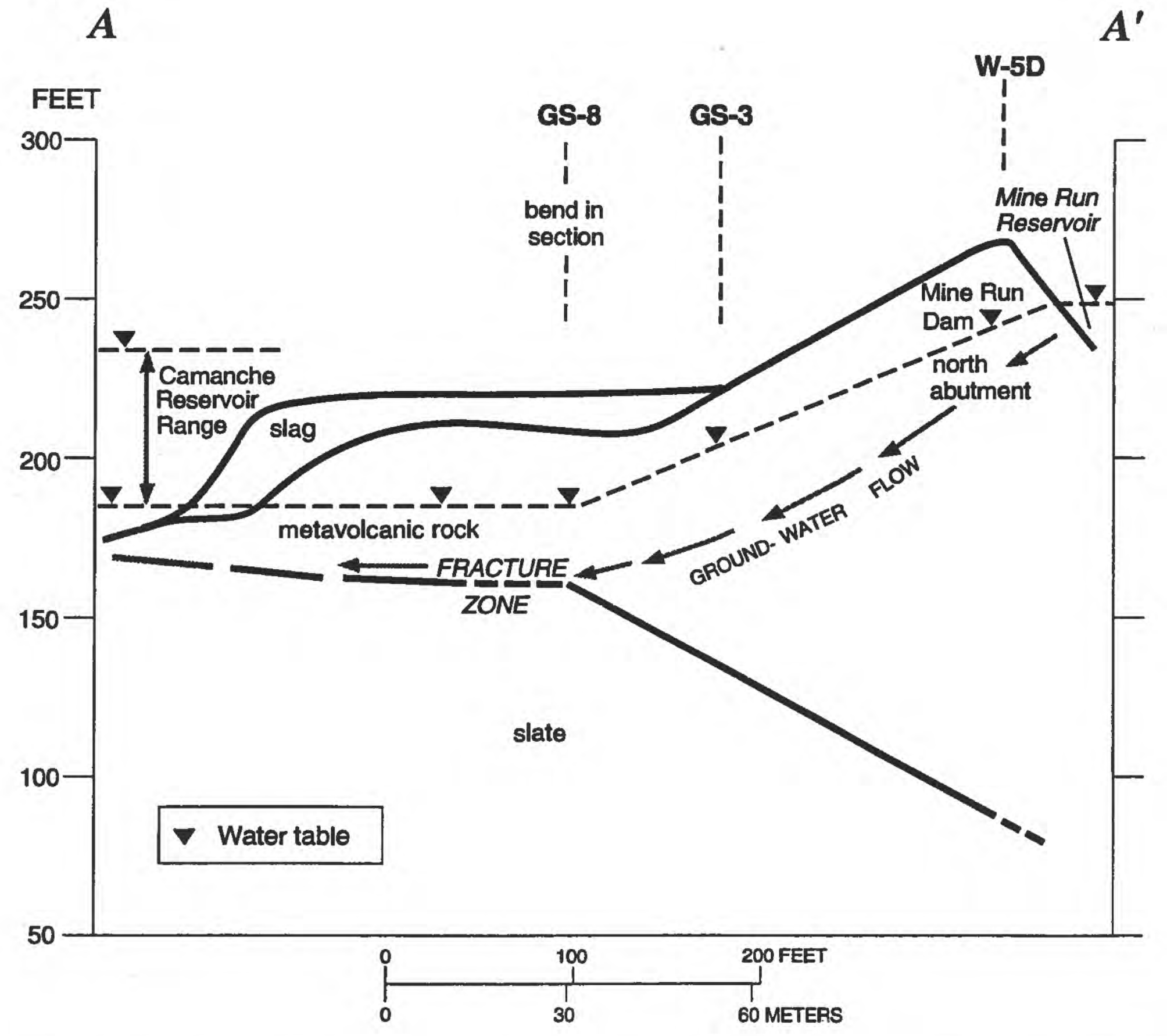

East

$\boldsymbol{A}^{\prime}$

Figure 4. Geologic section $A-A^{\prime}$ ' and water levels constructed using data from Camanche Reservolr, wells GS-3 and GS-8, and Mine Run Reservoir. 


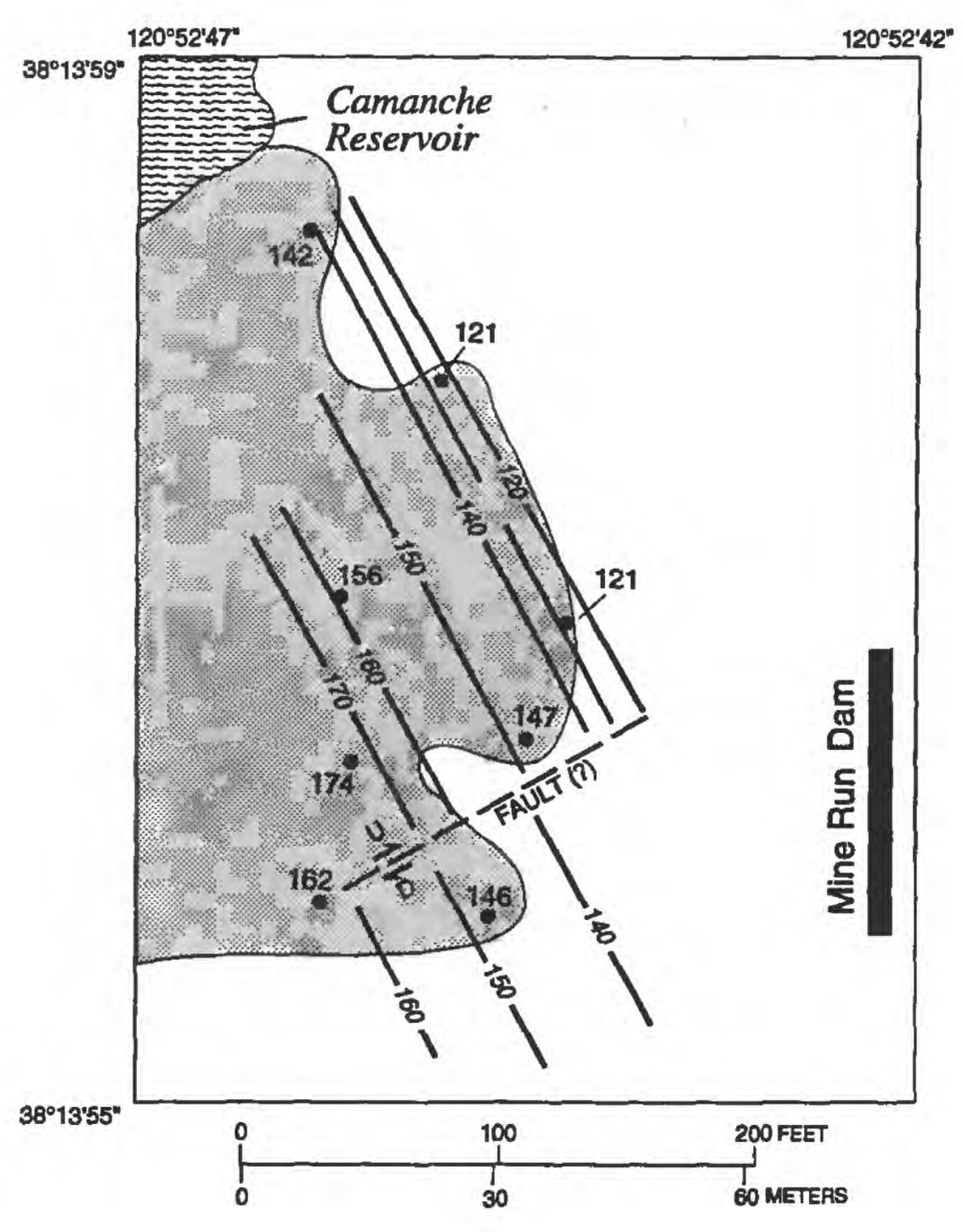

EXPLANATION

\begin{tabular}{|c|c|}
\hline & Slag \\
\hline & Metavolcanic rock \\
\hline$-\stackrel{U}{\Rightarrow}-$ & $\begin{array}{l}\text { Fault -- Approximately located. Arrow } \\
\text { shows relative horizontal movement. } \\
\text { U, upthrown side; D, downthrown side }\end{array}$ \\
\hline$-160-$ & $\begin{array}{l}\text { Subsurface contour - Shows altitude of } \\
\text { base of metavolcanic rock. Contour } \\
\text { interval } 10 \text { feet. Datum is sea level }\end{array}$ \\
\hline$e^{162}$ & $\begin{array}{l}\text { USGS well -- Number is altitude of contact } \\
\text { between slate and metavolcanic rock, in } \\
\text { feet above sea level }\end{array}$ \\
\hline
\end{tabular}

Figure 5. Subsurface altitude of the metavolcanic-slate contact. Contours and fault represent possible interpretation of geologic structure. Altitude of land surface is between 220 and 225 feet above sea level in slag area.

-4 , and -5 has shown a large number of fractures with a northeast strike. Another possibility is that the metavolcanic-slate contact may have been warped by anticlinal folding. However, the presence of a second fault is the preferred interpretation; the water-level and water-quality data presented in subsequent sections of this report are consistent with this interpretation.

\section{HYDRAULIC CHARACTERISTICS OF FRACTURED BEDROCK}

Tests for injection inflow were done in boreholes GS-1, $-2,-3,-4$, and -8 at constant head. The boreholes were filled with water and inflow rates were adjusted to a constant water level during the test. The injected water also was spiked with sodium bromide tracer to yield a bromide concentration of about $100 \mathrm{mg} / \mathrm{L}$. Boreholes GS-1, -2 , and -3 required less than $1.0 \mathrm{gal} / \mathrm{min}$ to maintain constant head. Boreholes GS-4 and -8 required initially 0.9 and 1.60 $\mathrm{gal} / \mathrm{min}$, respectively; the required injection rate gradually declined with time in each well during the test. Outflow was detected during these tests through fractures in the metavolcanic rock or along the metavolcanic-slate contact. The flowmeter data are in appendix 2.

Water-level recovery data were collected after pumping stopped at wells GS-1A, $-1 \mathrm{~B},-2,-3,-4 \mathrm{~A}$, $-4 B,-4 C$, and $-8 B$. In addition, drawdown data were collected during pumping at wells GS-5, $-6,-7$, and $-8 \mathrm{~A}$. Graphical presentations of these data are given in appendix 4. Well-bore storage can obscure aquifer-test data, particularly in large-diameter wells that tap low-permeability aquifers. This effect is minimized during late-time drawdown and recovery when the rate of water-level change is smallest. Papadopoulos and Cooper (1967) gave equations that quantify this effect. In general, well-bore-storage effects are negligible for times greater than $25\left(r^{2}\right) / T$, where $r$ is the casing radius and $T$ is the aquifer transmissivity. Using this criterion, late-time data from wells GS $-5,-7$, and $-8 \mathrm{~A}$ should be free of well-bore-storage effects. Other sites may show well-bore-storage effects, particularly in early-time data that tend to overestimate transmissivity. Gringarten (1982) also described methods to determine the presence of well-bore-storage effects. He noted that well bore storage yields a straight line with unit slope on a log-log plot of recovery data. Recovery data from wells GS-1A and $-4 A$ (appendix 4) showed the effects of well-bore storage on the basis of these criteria and, therefore, were not used to estimate hydraulic conductivity.

Water levels recovered very slowly in well GS-1B, indicating low hydraulic conductivity, and rapidly in well GS-8A, indicating much higher con- 
ductivity. The data for well GS-1B showed much fluctuation during recovery (appendix 4). The water level rose and declined, and water made a gurgling sound as it entered the well. Fractures supplying this interval that may have been completely dried out in the upper levels during sampling could explain the fluctuating recovery rates.

The Cooper-Jacob straight-line method of analysis (Driscoll, 1987) was applied to hydraulic data collected at the Penn Mine (appendix 4). Drawdown data, in feet below the measuring point, were plotted relative to the logarithm of time, in minutes since initiation of pumping. Recovery data (residual drawdown in feet) were plotted against dimensionless time $\left(t / t^{\prime}=\right.$ time since pumping started/time since pumping stopped). Transmissivity, $T$, can be estimated from the following expression:

$$
T=\frac{264 Q \log \left(t / t^{\circ}\right)}{\Delta s}
$$

where

$Q=$ pumping rate (gallons per minute),

$t$ and $t^{\prime}=$ time (minutes), and

$s=$ drawdown (feet).

Residual drawdown, $s^{\prime}$, may be substituted for drawdown, $s$, in equation 1 . In the absence of boundary and well-bore-storage effects, a plot of drawdown and $\log \left(\mathrm{t} / \mathrm{t}^{\prime}\right)$ should form a straight line.
When $t / t^{\prime}=10$, then $\log \left(t / t^{\prime}\right)=1$. Therefore, $T=$ $264 Q /(\Delta s)$ for one $\log$ cycle $\left(t / t^{\prime}=10\right)$. The drawdown $(\Delta s)$, or recovery, was measured over one log cycle during late time. An estimate of $T$ was determined using the value for $(\Delta s)$ and the average value for $Q$ during the test (appendix 4). Hydraulic conductivity $(K)$ was calculated by dividing $T$ by the thickness of the rock unit in the specified interval. Estimates of transmissivity and hydraulic conductivity are presented in table 1. This method of analysis tends to overestimate values for $T$ and $K$, particularly in low-permeability rock (for example, slate). The highest calculated value for $K$ is $57 \mathrm{ft} / \mathrm{d}$ at well GS-5, which penetrates metavolcanic rock and slate. Because fractures are primarily in the metavolcanic unit, $K$ values are attributed to metavolcanic rock in wells that also penetrate the slate unit. The lowest value for $K$ is $0.008 \mathrm{ft} / \mathrm{d}$ at well GS-1B (slate). In general, values of $K$ are higher in the metavolcanic rock compared with those in the slate unit, particularly in borehole GS-8 (table 1). Most fractures are along or near the contact between the metavolcanic rock and slate units, chiefly in the metavolcanic unit. As a result, the largest volume of ground-water flow is expected to be in a zone along or adjacent to this contact.

Transmissivity values also were estimated from specific capacity using a method described by Huntley and others (1992). The specific capacity of a well is calculated by dividing the pumping rate $(Q)$ by drawdown $(s)$ after a specific period of time. Specific

Table 1. Estimates of transmissivity and hydraulic conductivity at the Penn Mine, April 1992

[mv, metavolcanic rock; sl, slate; ft, foot; ft/d, foot per day; $\mathrm{ft}^{2} / \mathrm{d}$, square foot per day]

\begin{tabular}{|c|c|c|c|c|c|c|c|}
\hline \multirow{2}{*}{ Well } & \multirow{2}{*}{$\begin{array}{c}\text { Depth } \\
\text { interval } \\
\text { (ft below } \\
\text { land } \\
\text { surface) }\end{array}$} & \multirow{2}{*}{$\begin{array}{l}\text { Rock } \\
\text { type }\end{array}$} & \multirow{2}{*}{$\begin{array}{l}\text { Thickness of } \\
\text { saturated } \\
\text { zone } \\
\text { (ft) }\end{array}$} & \multicolumn{2}{|c|}{$\begin{array}{l}\text { Cooper-Jacob, } \\
\text { straight-line method }\end{array}$} & \multicolumn{2}{|c|}{$\begin{array}{l}\text { Huntley and others, } 1992 \text {, } \\
\text { specific-capacity method }\end{array}$} \\
\hline & & & & $\begin{array}{c}\text { Transmissivity } \\
\left(\mathrm{ft}^{2} / \mathrm{d}\right)\end{array}$ & $\begin{array}{c}\text { Hydraulic } \\
\text { conductivity } \\
(\mathrm{ft} / \mathrm{d})\end{array}$ & $\begin{array}{l}\text { Transmissivity } \\
\left(\mathrm{ft}^{2} / \mathrm{d}\right)\end{array}$ & $\begin{array}{c}\text { Hydraulic } \\
\text { conductivity } \\
(\mathrm{ft} / \mathrm{d})\end{array}$ \\
\hline GS-1B & $80-200$ & sl & 120 & 0.9 & 0.008 & 0.06 & 0.0005 \\
\hline GS-2 & $40-200$ & $\mathrm{mv}+\mathrm{sl}$ & ${ }^{1} 36$ & 1.5 & .04 & .8 & .02 \\
\hline GS-3 & $30-200$ & $\mathrm{mv}+\mathrm{sl}$ & ${ }^{1} 75$ & 3.5 & .05 & .9 & .01 \\
\hline GS-4B & $55-80$ & $\mathrm{mv}$ & 25 & 2.1 & .08 & 2.0 & .08 \\
\hline GS-4C & $80-200$ & sl & 100 & 4.6 & .05 & .2 & .002 \\
\hline GS-5 & $30-200$ & $\mathrm{mv}+\mathrm{sl}$ & ${ }^{1} 46$ & 2,600 & 57 & 2,300 & 50 \\
\hline GS-6 & $30-400$ & $\mathrm{mv}+\mathrm{sl}$ & ${ }^{1} 16$ & 2.7 & .2 & 1.6 & .1 \\
\hline GS-7 & ${ }^{2} 39-50$ & $\mathrm{mv}+\mathrm{sl}$ & 58 & 190 & 3.3 & 150 & 2.6 \\
\hline GS-8A & $30-76$ & mv & 33 & 1,400 & 42 & 350 & 11 \\
\hline GS-8B & $76-200$ & sl & 124 & 2.3 & .02 & .2 & .002 \\
\hline
\end{tabular}

${ }^{1}$ Thickness of saturated zone refers to metavolcanic rock thickness in wells of mixed lithology.

${ }^{2}$ Well GS-7 drilled to 200 feet below land surface, caved in below 50 feet below land surface; 3 -inch diameter, perforated casing installed from land surface to 50 feet below land surface. 


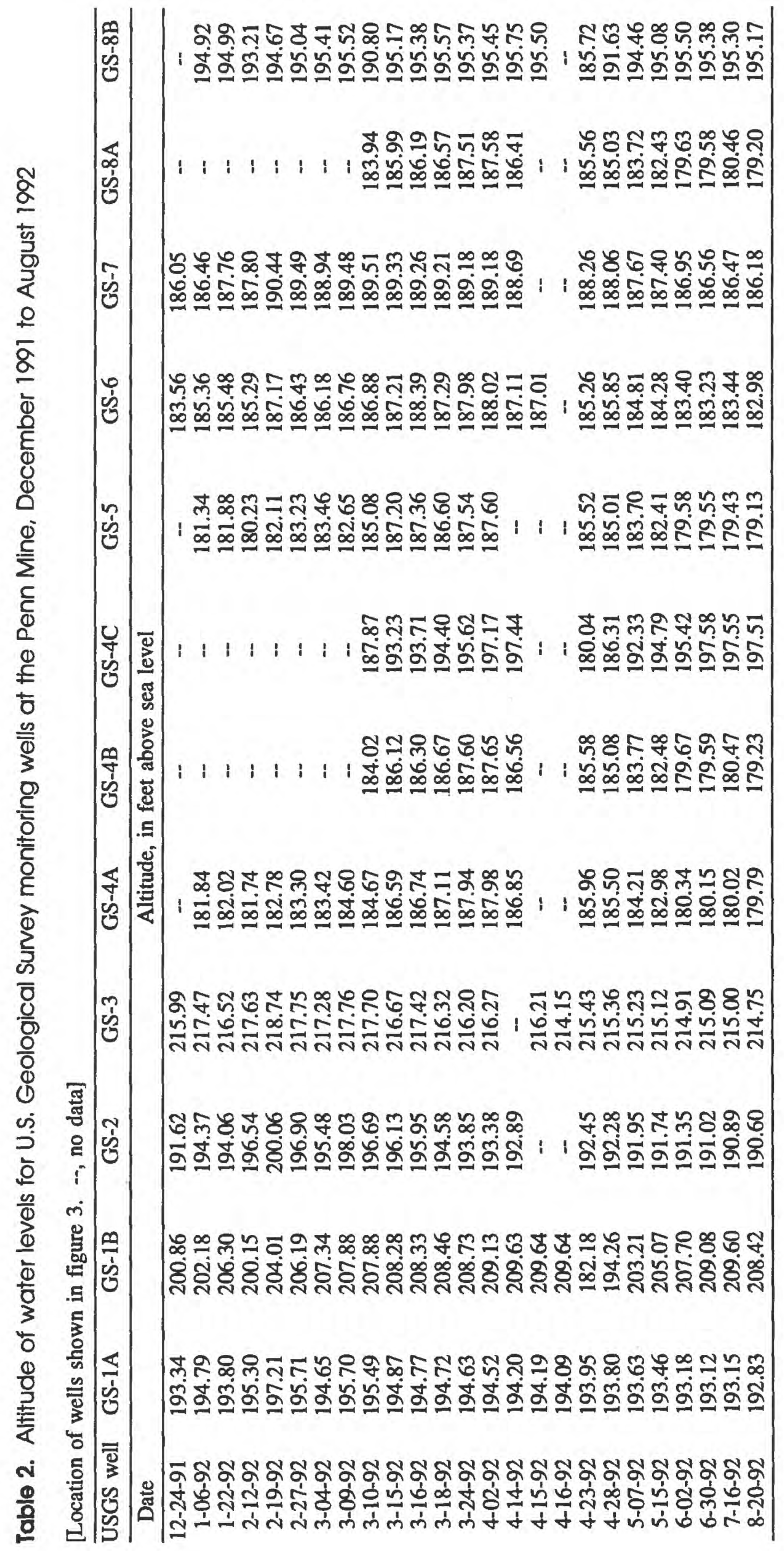




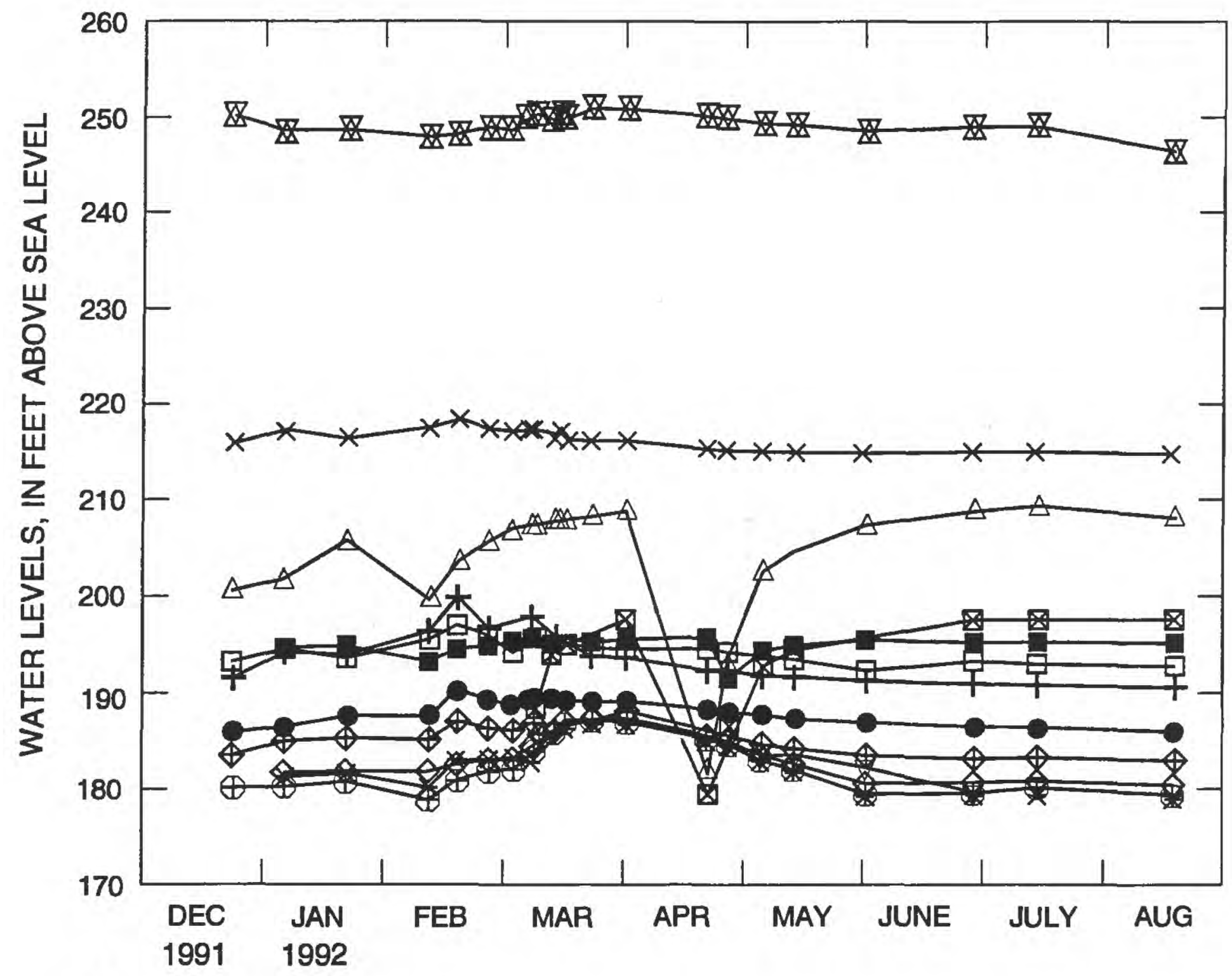

$\boldsymbol{A}$

EXPLANATION

$\begin{array}{llll}\square & \text { GS-1A, 0-80 ft } & \bullet & \text { GS-5, 0-200 ft } \\ \triangle & \text { GS-1B, 80-200 ft } & \oplus & \text { GS-6, 0-400 ft } \\ + & \text { GS-2, 0-200 ft } & \bullet & \text { GS-7, 0-200 ft } \\ \times & \text { GS-3, 0-200 ft } & \bullet & \text { GS-8B, 76-200 ft } \\ \diamond & \text { GS-4A, 0-55 ft } & \oplus & \text { CAMANCHE RESERVOIR } \\ \nabla & \text { GS-4B, 55-80 ft } & \bigotimes & \text { MINE RUN RESERVOIR } \\ \otimes & \text { GS-4C, 80-200 ft } & & \end{array}$

Figure 6. Fluctuations in water levels in Camanche Reservolr, Mine Run Reservoir, and in wells at the Penn Mine. A. Water levels for Camanche Resevoir, Mine Run Reservoir, and wells GS-1 through GS-8. B. Water levels for Camanche Reservoir and wells GS-4A, GS-5, GS-6, and GS-7 shown at an expanded scale. Water levels for GS-8A are the same as the levels in GS-4A. Data for Camanche Reservoir from East Bay Municipal Utility Dlstrict (written commun., 1993).

capacity $(Q / s)$ commonly has been used to estimate aquifer transmissivity in alluvial systems assuming a linear relation. Huntley and others (1992) found that $Q / s$ in fractured rock systems was related to $T$ as a log function, with a potential error of about $1.1 \mathrm{log}$ cycles:

$$
T=0.29(Q / s)^{1.18} \text {. }
$$

Values for transmissivity and hydraulic conductivity calculated by this method also are given in table 1 and generally are within one order of magnitude of 


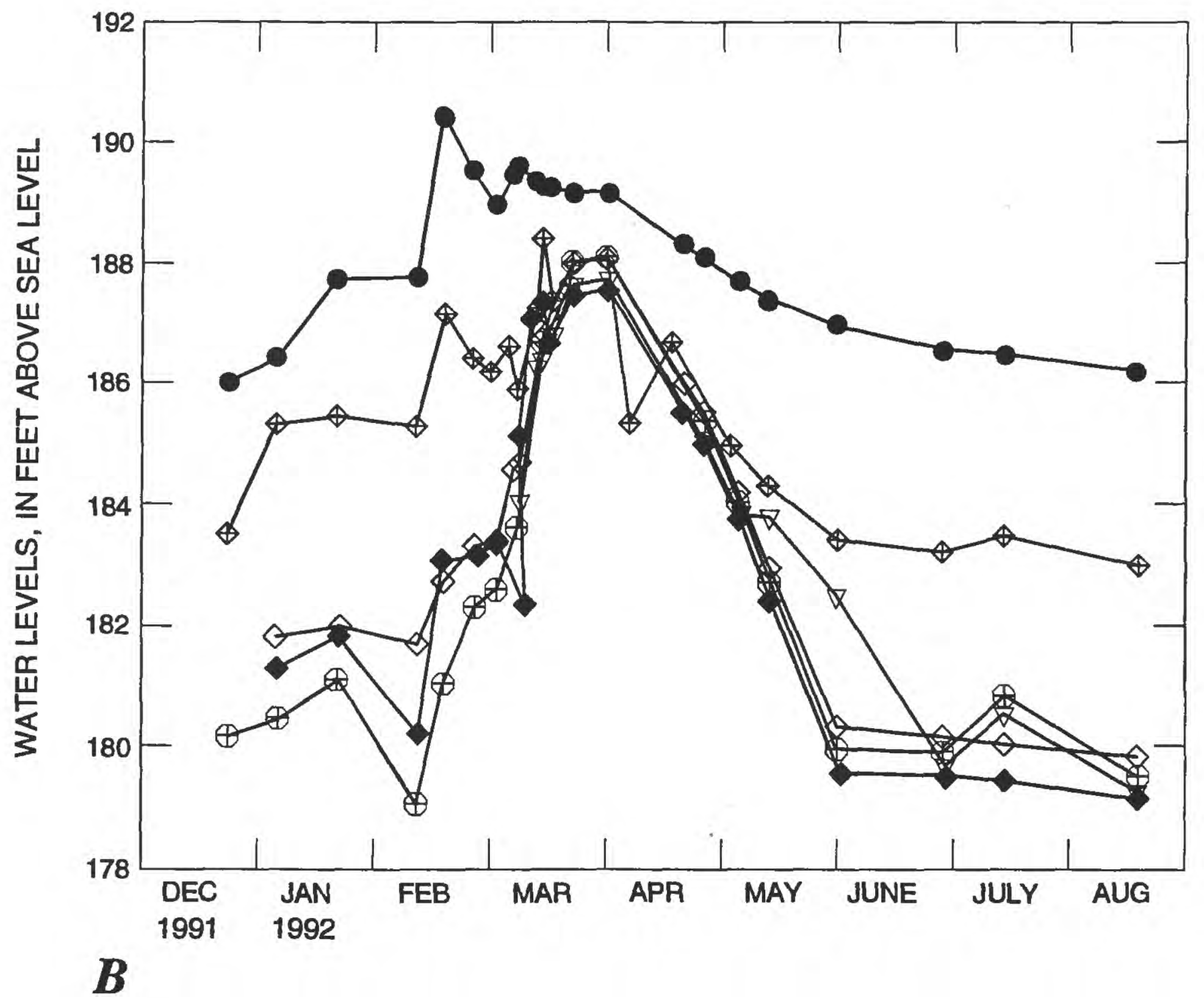

Figure 6. Continued.

values estimated using the Cooper-Jacob straight-line method. The Huntley specific-capacity method consistently yields lower values for $T$ and $K$, which may better represent actual conditions in lowpermeability systems.

The mean hydraulic conductivity $(K)$ for the metavolcanic unit from both methods was about 10 to 50 times higher than in the slate unit. The median value of $K$ from both methods was $0.1 \mathrm{ft} / \mathrm{d}$ in the metavolcanic unit. The median value of $K$ determined for the slate unit ranged from 0.002 (Huntley method) to $0.01 \mathrm{ft} / \mathrm{d}$ (Cooper-Jacob method).

\section{WATER LEVELS}

Ground-water levels for USGS wells at the Penn Mine during December 1991 to August 1992 are given in table 2. Water-level data were collected at each of the eight borehole sites (GS-1 through -8). Inflatable packers were installed at three sites (GS -1, -4 , and -8 ) to isolate fracture zones of interest. The remaining boreholes represent average water-level and water-quality conditions over the entire length of open boreholes. Water-level altitudes were consistently higher in the slate than in the overlying metavolcanic rock at individual well sites where packers separate the rock types. This observation can be explained by a recharge source for the slate at a higher altitude than the metavolcanic rock. Figure 6 shows fluctuations in water-level altitudes for the wells during December 1991 to August 1992. Altitudes are highest in wells near Mine Run Dam during periods of recharge in the winter months. Water levels are lowest in wells near Camanche Reservoir during periods of dry weather (figs. 3 and 6). The significant declines in water-level altitudes in wells such as GS-1B during February and April 1992 were caused by the very slow recovery after pumping water from low-permeability intervals during water-quality sampling. Water-level altitudes in wells GS-4A, -5 , and $-8 \mathrm{~A}$ are nearly identical to levels in Camanche Reservoir, indicating hydraulic connection. Water levels in these wells are apparently above the level of Camanche Reservoir in winter months and below res- 


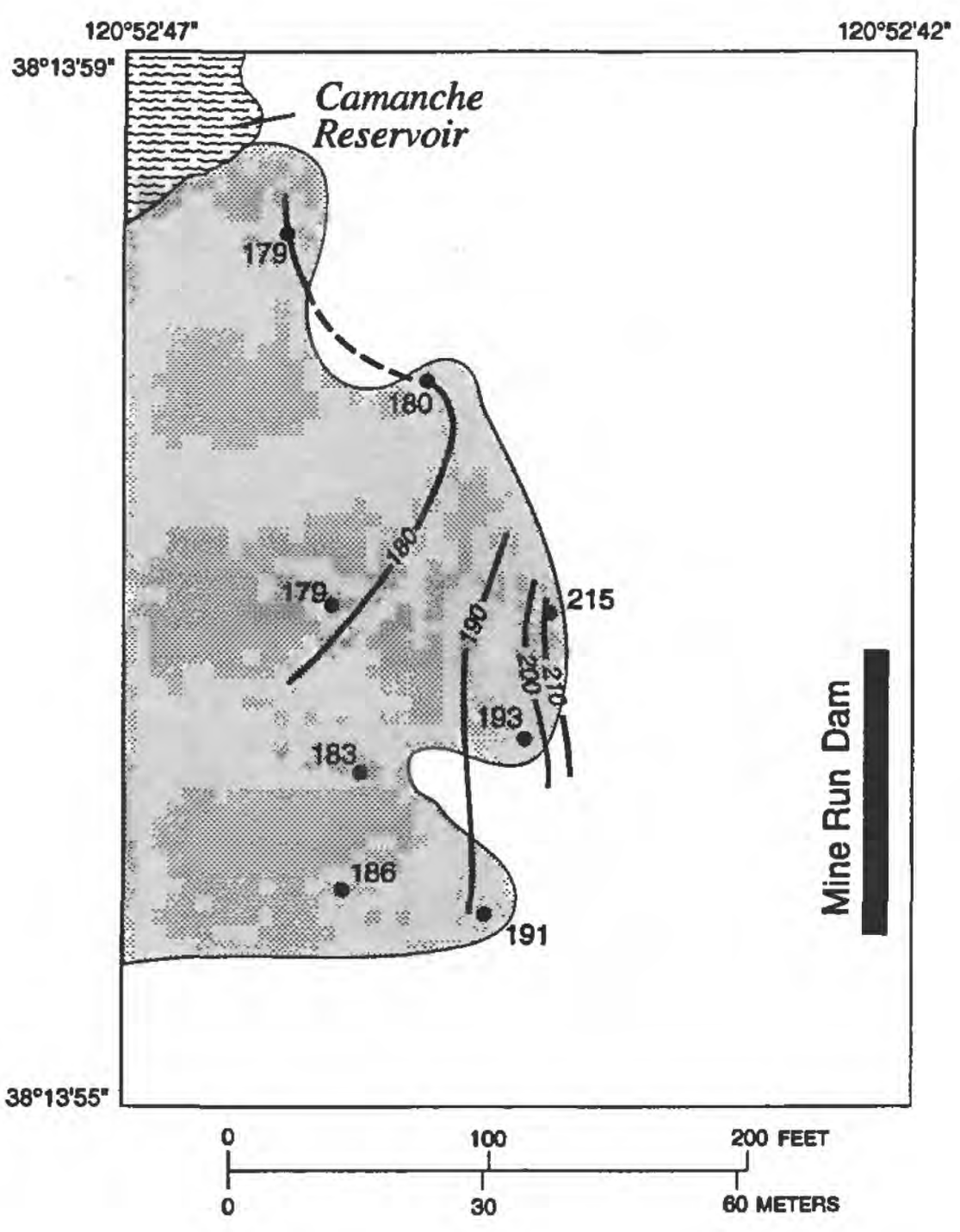

EXPLANATION

\begin{tabular}{|l}
\hline Slag \\
\hline Metavolcanic rock \\
$\begin{array}{l}\text { Water-level contour - Shows altitude of } \\
\text { water level. Dashed where approximately } \\
\text { located. Contour interval 10 feet. Datum } \\
\text { is sea level }\end{array}$ \\
$\begin{array}{l}\text { USGS well - Number is altitude of water } \\
\text { level, in feet above sea level }\end{array}$
\end{tabular}

Figure 7. Water levels in the metavolcanic unit, August 1992.

ervoir level in summer months. This observation may be clarified by resurveying well altitudes and the benchmark on Mine Run Dam to confirm groundwater altitudes. Wells GS-5 and $-8 \mathrm{~A}$ yielded the highest hydraulic conductivities among the tested sites (table 1); the wells may intersect a major conduit for ground-water flow. Well GS-4 is near the north end of the slag pile, and GS-5 is closest to Camanche Reservoir to the northwest. Well GS-8A is about 100 $\mathrm{ft}$ south of GS-4 (fig. 3).

Water-surface altitude in Camanche Reservoir was about $180 \mathrm{ft}$ above sea level during low stage in JuneAugust 1992. Water-surface altitude in Mine Run Reservoir fluctuated between about 245 and $250 \mathrm{ft}$ above sea level during the same period. Groundwater levels in wells GS-1 through -8 lie between 180 and $220 \mathrm{ft}$ above sea level; the general hydraulic gradient during the study period was from Mine Run Reservoir through the ground-water system to Camanche Reservoir.

Water-level altitudes in the metavolcanic unit are contoured in figure 7. Formation-specific data were used for sites GS-1, -4 , and -8 . Water elevations for the other sites were measured in wells that penetrate metavolcanic rock and slate over the length of the borehole (figs. 3 and 7). Water levels in boreholes that penetrate units of contrasting permeability normally reflect the unit of highest permeability. Consequently, water levels in boreholes penetrating metavolcanic rock and slate were assumed to represent hydraulic conditions in the metavolcanic rock, which generally has a much higher permeability.

The average hydraulic gradient is toward the west over most of the study area. The primary flow path seems to be to the northwest in the northern half of the study area. The general direction of ground-water flow is shown in cross section in figure 4 . The orientation of the acid-mine-drainage plume, described in the following section, is toward the northwest and originates near the northern section of Mine Run Dam. When the level in Camanche Reservoir rose above an altitude of about $182 \mathrm{ft}$ above sea level in March 1992, the hydraulic gradient apparently reversed direction, indicating flow from Camanche Reservoir to the ground-water system.

\section{GEOCHEMISTRY}

\section{RESULTS OF SAMPLING}

Water-quality data for January, February, April, and December 1992 are summarized in table 3. Zones of low permeability in wells with packers may produce samples that do not represent ambient ground-water quality prior to drilling because of contamination that cascaded downward from fractures in the overlying metavolcanic rock prior to installation of the packers. Conversely, samples collected 
Table 3. Water-quality data for Mine Run Reservoir and wells at the Penn Mine

[State well number: All wells are in 4N/10E, township and range. MRR, Mine Run Reservoir. ${ }^{\circ} \mathrm{C}$, degrees Celsius; $\mathrm{ft}$, foot; $\mu \mathrm{S} / \mathrm{cm}$, microsiemens per centimeter; $\mathrm{mg} / \mathrm{L}$, milligram per liter; $\mathrm{mV}$, millivolts; $\mu \mathrm{g} / \mathrm{L}$, microgram per liter: <, actual value is less than value shown; --, no data]

\begin{tabular}{|c|c|c|c|c|c|c|c|c|c|c|c|}
\hline $\begin{array}{l}\text { Well } \\
\text { name }\end{array}$ & $\begin{array}{l}\text { State } \\
\text { well } \\
\text { No. }\end{array}$ & Date & $\begin{array}{l}\text { Depth } \\
\text { of } \\
\text { well, } \\
\text { total } \\
\text { (ft) }\end{array}$ & $\begin{array}{l}\text { Spe- } \\
\text { cific } \\
\text { con- } \\
\text { duct- } \\
\text { ance } \\
(\mu \mathrm{S} / \mathrm{cm})\end{array}$ & $\begin{array}{l}\text { pH water } \\
\text { whole } \\
\text { field } \\
\text { (stand- } \\
\text { ard } \\
\text { units) }\end{array}$ & $\begin{array}{l}\text { Redox } \\
\text { poten- } \\
\text { tial } \\
(\mathrm{mV})^{1}\end{array}$ & $\begin{array}{l}\text { Temper- } \\
\text { ature, } \\
\text { water } \\
\left({ }^{\circ} \mathrm{C}\right)\end{array}$ & $\begin{array}{l}\text { Oxygen } \\
\text { dis- } \\
\text { solved } \\
(\mathrm{mg} / \mathrm{L})\end{array}$ & $\begin{array}{l}\text { Calcium, } \\
\text { dis- } \\
\text { solved } \\
(\mathrm{mg} / \mathrm{L})\end{array}$ & $\begin{array}{l}\text { Magne- } \\
\text { sium, } \\
\text { dis- } \\
\text { solved } \\
(\mathrm{mg} / \mathrm{L})\end{array}$ & $\begin{array}{c}\text { Sodium, } \\
\text { dis- } \\
\text { solved } \\
(\mathrm{mg} / \mathrm{L})\end{array}$ \\
\hline GS-1A & $4 \mathrm{GlA}$ & $\begin{array}{r}1-29-92 \\
4-17-92 \\
12-15-92\end{array}$ & $\begin{array}{l}80 \\
80 \\
80\end{array}$ & $\begin{array}{l}5,060 \\
4,950 \\
4,980\end{array}$ & $\begin{array}{l}5.8 \\
5.1 \\
4.6\end{array}$ & $\begin{array}{r}-\overline{-} \\
460 \\
499\end{array}$ & $\begin{array}{l}18.5 \\
18.0 \\
18.5\end{array}$ & $\begin{array}{l}0.8 \\
-- \\
0.2\end{array}$ & $\begin{array}{l}540 \\
480 \\
470\end{array}$ & $\begin{array}{l}350 \\
350 \\
400\end{array}$ & $\begin{array}{l}370 \\
280 \\
270\end{array}$ \\
\hline GS-1B & $4 \mathrm{G1B}$ & $\begin{array}{l}2-03-92 \\
4-18-92\end{array}$ & $\begin{array}{l}200 \\
200\end{array}$ & $\begin{array}{l}5,200 \\
5,980\end{array}$ & $\begin{array}{l}6.7 \\
7.2\end{array}$ & $2 \overline{263}$ & $\begin{array}{l}18.5 \\
18.5\end{array}$ & $\begin{array}{l}0.9 \\
--\end{array}$ & $\begin{array}{l}540 \\
480\end{array}$ & $\begin{array}{l}320 \\
260\end{array}$ & $\begin{array}{l}410 \\
810\end{array}$ \\
\hline GS-2 & $4 \mathrm{G} 2$ & $\begin{array}{l}1-28-92 \\
4-14-92\end{array}$ & $\begin{array}{l}200 \\
200\end{array}$ & $\begin{array}{l}1,430 \\
1,810\end{array}$ & $\begin{array}{l}7.6 \\
7.8\end{array}$ & $3 \overline{19}$ & $\begin{array}{l}18.5 \\
18.5\end{array}$ & $\overline{0.9}$ & $\begin{array}{l}72 \\
72\end{array}$ & $\begin{array}{l}38 \\
34\end{array}$ & $\begin{array}{l}180 \\
320\end{array}$ \\
\hline GS-3 & $4 \mathrm{G} 3$ & $\begin{array}{r}1-30-92 \\
4-15-92 \\
12-19-92\end{array}$ & $\begin{array}{l}200 \\
200 \\
200\end{array}$ & $\begin{array}{l}5,190 \\
4,600 \\
5,660\end{array}$ & $\begin{array}{l}4.7 \\
4.8 \\
5.1\end{array}$ & $\begin{array}{r}-- \\
451 \\
446\end{array}$ & $\begin{array}{l}19.5 \\
19.5 \\
19.5\end{array}$ & $\begin{array}{l}0.8 \\
1.7 \\
0.2\end{array}$ & $\begin{array}{l}480 \\
440 \\
510\end{array}$ & $\begin{array}{l}600 \\
550 \\
690\end{array}$ & $\begin{array}{r}57 \\
57 \\
100\end{array}$ \\
\hline GS-4A & $4 G 4 A$ & $\begin{array}{l}4-16-92 \\
4-16-92\end{array}$ & $\begin{array}{l}55 \\
55\end{array}$ & $\begin{array}{l}2,430 \\
2,430\end{array}$ & $\begin{array}{l}5.7 \\
5.7\end{array}$ & $\begin{array}{l}387 \\
387\end{array}$ & $\begin{array}{l}18.5 \\
18.5\end{array}$ & - & $\begin{array}{l}210 \\
200\end{array}$ & $\begin{array}{l}260 \\
240\end{array}$ & $\begin{array}{l}29 \\
31\end{array}$ \\
\hline GS-4B & $4 G 4 B$ & $\begin{array}{r}1-31-92 \\
4-16-92 \\
12-15-92\end{array}$ & $\begin{array}{l}80 \\
80 \\
80\end{array}$ & $\begin{array}{r}-\overline{3} \\
3,360\end{array}$ & $\begin{array}{l}5.6 \\
6.6 \\
6.2\end{array}$ & $\begin{array}{l}400 \\
428\end{array}$ & $\begin{array}{l}16.0 \\
19.0 \\
16.5\end{array}$ & $\bar{z} .0$ & $\begin{array}{l}380 \\
360 \\
390\end{array}$ & $\begin{array}{l}290 \\
250 \\
310\end{array}$ & $\begin{array}{r}110 \\
83 \\
63\end{array}$ \\
\hline GS-4C & $4 \mathrm{G} 4 \mathrm{C}$ & $\begin{array}{l}2-03-92 \\
4-18-92\end{array}$ & $\begin{array}{l}200 \\
200\end{array}$ & $\begin{array}{l}3,440 \\
4,380\end{array}$ & $\begin{array}{l}6.7 \\
7.3\end{array}$ & $29 \overline{3}$ & $\begin{array}{l}19.0 \\
19.0\end{array}$ & $\begin{array}{l}-- \\
--\end{array}$ & $\begin{array}{l}360 \\
380\end{array}$ & $\begin{array}{l}280 \\
270\end{array}$ & $\begin{array}{l}150 \\
360\end{array}$ \\
\hline GS-5 & $4 G 5$ & $\begin{array}{r}1-27-92 \\
4-13-92 \\
12-18-92\end{array}$ & $\begin{array}{l}201.5 \\
201.5 \\
201.5\end{array}$ & $\begin{array}{l}3,730 \\
3,430 \\
4,300\end{array}$ & $\begin{array}{l}5.6 \\
5.4 \\
4.6\end{array}$ & $\begin{array}{l}438 \\
467\end{array}$ & $\begin{array}{l}17.5 \\
17.5 \\
18.0\end{array}$ & $\begin{array}{l}0.3 \\
0.5 \\
0.5\end{array}$ & $\begin{array}{l}440 \\
360 \\
430\end{array}$ & $\begin{array}{l}390 \\
320 \\
380\end{array}$ & $\begin{array}{l}48 \\
49 \\
62\end{array}$ \\
\hline GS-6 & $4 \mathrm{G} 6$ & $\begin{array}{l}1-29-92^{2} \\
1-29-92^{3} \\
4-15-92^{4} \\
4-15-92^{4}\end{array}$ & $\begin{array}{l}401 \\
401 \\
401 \\
401\end{array}$ & $\begin{array}{l}11,430 \\
14,000 \\
18,000 \\
18,000\end{array}$ & $\begin{array}{l}4.1 \\
4.5 \\
4.2 \\
4.1\end{array}$ & $\begin{array}{r}-- \\
\overline{-} \\
484\end{array}$ & $\begin{array}{l}16.5 \\
17.5 \\
18.5 \\
18.5\end{array}$ & $\begin{array}{l}0.5 \\
0.1 \\
0.5 \\
--\end{array}$ & $\begin{array}{l}520 \\
570 \\
560 \\
600\end{array}$ & $\begin{array}{l}430 \\
380 \\
290 \\
270\end{array}$ & $\begin{array}{l}1,200 \\
1,700 \\
3,200 \\
3,100\end{array}$ \\
\hline GS-7 & $4 \mathrm{G} 7$ & $\begin{array}{l}1-28-92 \\
4-14-92\end{array}$ & $\begin{array}{l}202 \\
202\end{array}$ & $\begin{array}{l}3,150 \\
2,390\end{array}$ & $\begin{array}{l}4.7 \\
4.9\end{array}$ & $5 \overline{-}$ & $\begin{array}{l}18.5 \\
18.5\end{array}$ & $\begin{array}{l}0.3 \\
1.0\end{array}$ & $\begin{array}{l}390 \\
300\end{array}$ & $\begin{array}{l}250 \\
170\end{array}$ & $\begin{array}{l}38 \\
28\end{array}$ \\
\hline GS-8A & $4 G 8 A$ & $\begin{array}{r}1-31-92 \\
4-14-92 \\
12-04-92\end{array}$ & $\begin{array}{l}76 \\
76 \\
76\end{array}$ & $\begin{array}{l}6,900 \\
5,660 \\
6,230\end{array}$ & $\begin{array}{l}3.7 \\
3.7 \\
3.8\end{array}$ & $\begin{array}{r}-- \\
500 \\
432\end{array}$ & $\begin{array}{l}18.0 \\
18.5 \\
18.0\end{array}$ & $\begin{array}{l}1.9 \\
0.2 \\
0.2\end{array}$ & $\begin{array}{l}510 \\
480 \\
440\end{array}$ & $\begin{array}{l}540 \\
580 \\
620\end{array}$ & $\begin{array}{l}54 \\
60 \\
64\end{array}$ \\
\hline GS-8B & $4 G 8 B$ & $\begin{array}{l}2-03-92 \\
4-17-92\end{array}$ & $\begin{array}{l}200 \\
200\end{array}$ & $\begin{array}{l}5,540 \\
6,200\end{array}$ & $\begin{array}{l}4.1 \\
4.3\end{array}$ & $4 \overline{20}$ & $\begin{array}{l}16.5 \\
18.5\end{array}$ & $\ddot{-}$ & $\begin{array}{l}550 \\
460\end{array}$ & $\begin{array}{l}350 \\
460\end{array}$ & $\begin{array}{l}190 \\
390\end{array}$ \\
\hline MRR-A & & $12-22-92$ & - & 8,000 & 2.8 & 686 & 14.0 & 4.7 & 430 & 810 & 73 \\
\hline MRR-A ${ }^{6}$ & & $12-22-92$ & - & 8,000 & 2.8 & -- & 14.0 & 4.7 & 280 & 450 & 45 \\
\hline MRR-B ${ }^{5}$ & & $12-22-92$ & - & 9,300 & 2.8 & 728 & 13.5 & 3.9 & -- & - & - \\
\hline
\end{tabular}

Footnotes at end of table. 
Table 3. Water-quality data for Mine Run Reservoir and wells at the Penn Mine--Continued

\begin{tabular}{|c|c|c|c|c|c|c|c|c|c|c|c|}
\hline $\begin{array}{l}\text { Well } \\
\text { name }\end{array}$ & $\begin{array}{l}\text { State } \\
\text { well } \\
\text { No. }\end{array}$ & Date & $\begin{array}{l}\text { Potas- } \\
\text { sium, } \\
\text { dis- } \\
\text { solved } \\
(\mathrm{mg} / \mathrm{L})\end{array}$ & $\begin{array}{c}\text { Sulfate, } \\
\text { dis- } \\
\text { solved } \\
(\mathrm{mg} / \mathrm{L})\end{array}$ & $\begin{array}{l}\text { Chlo- } \\
\text { ride, } \\
\text { dis- } \\
\text { solved } \\
(\mathrm{mg} / \mathrm{L})\end{array}$ & $\begin{array}{l}\text { Fluo- } \\
\text { ride, } \\
\text { dis- } \\
\text { solved } \\
(\mathrm{mg} / \mathrm{L})\end{array}$ & $\begin{array}{l}\text { Bromide, } \\
\text { dis- } \\
\text { solved } \\
(\mathrm{mg} / \mathrm{L})\end{array}$ & $\begin{array}{l}\text { Silica, } \\
\text { dis- } \\
\text { solved } \\
(\mathrm{mg} / \mathrm{L})\end{array}$ & $\begin{array}{c}\text { Solids, } \\
\text { residue } \\
\text { at } 180^{\circ} \mathrm{C} \text {, } \\
\text { dis- } \\
\text { solved } \\
(\mathrm{mg} / \mathrm{L})\end{array}$ & $\begin{array}{l}\text { Alum- } \\
\text { inum, } \\
\text { dis- } \\
\text { solved } \\
(\mu \mathrm{g} / \mathrm{L})\end{array}$ & $\begin{array}{c}\text { Cadium, } \\
\text { dis- } \\
\text { solved } \\
(\mu \mathrm{g} / \mathrm{L})\end{array}$ \\
\hline$\overline{\text { GS-1A }}$ & 4G1A & $\begin{array}{r}1-29-92 \\
4-17-92 \\
12-15-92\end{array}$ & $\begin{array}{l}13 \\
11 \\
10\end{array}$ & $\begin{array}{l}3,500 \\
3,500 \\
3,700\end{array}$ & $\begin{array}{r}120 \\
97 \\
78\end{array}$ & $\begin{array}{l}1.2 \\
1.5 \\
1.3\end{array}$ & $\begin{array}{c}1.9 \\
.88 \\
.39\end{array}$ & $\begin{array}{l}35 \\
42 \\
47\end{array}$ & $\begin{array}{l}5,750 \\
5,580 \\
5,540\end{array}$ & $\begin{array}{r}570 \\
3,800 \\
10,000\end{array}$ & $\begin{array}{l}1,600 \\
2,100 \\
2,300\end{array}$ \\
\hline GS-1B & $4 \mathrm{G} 1 \mathrm{~B}$ & $\begin{array}{l}2-03-92 \\
4-18-92\end{array}$ & $\begin{array}{l}14 \\
18\end{array}$ & $\begin{array}{l}3,300 \\
3,000\end{array}$ & $\begin{array}{l}200 \\
570\end{array}$ & $\begin{array}{c}1.5 \\
.90\end{array}$ & $\begin{array}{l}2.9 \\
4.5\end{array}$ & $\begin{array}{l}29 \\
13\end{array}$ & $\begin{array}{l}5,760 \\
6,090\end{array}$ & $\begin{array}{l}30 \\
30\end{array}$ & $\begin{array}{r}1,400 \\
440\end{array}$ \\
\hline GS-2 & $4 \mathrm{G} 2$ & $\begin{array}{l}1-28-92 \\
4-14-92\end{array}$ & $\begin{array}{l}4.9 \\
5.5\end{array}$ & $\begin{array}{l}370 \\
450\end{array}$ & $\begin{array}{l}130 \\
240\end{array}$ & $\begin{array}{l}.20 \\
.20\end{array}$ & $\begin{array}{l}1.8 \\
1.6\end{array}$ & $\begin{array}{l}18 \\
16\end{array}$ & $\begin{array}{r}992 \\
3,750\end{array}$ & $\begin{array}{l}<10 \\
<10\end{array}$ & $\begin{array}{l}<10 \\
<10\end{array}$ \\
\hline GS-3 & 4G3 & $\begin{array}{r}1-30-92 \\
4-15-92 \\
12-19-92\end{array}$ & $\begin{array}{l}4.9 \\
3.9 \\
5.8\end{array}$ & $\begin{array}{l}3,700 \\
3,700 \\
4,400\end{array}$ & $\begin{array}{l}22 \\
21 \\
36\end{array}$ & $\begin{array}{c}2.1 \\
.30 \\
.40\end{array}$ & $\begin{array}{l}.15 \\
.10 \\
.15\end{array}$ & $\begin{array}{l}71 \\
59 \\
72\end{array}$ & $\begin{array}{l}5,930 \\
5,290 \\
6,590\end{array}$ & $\begin{array}{l}6,900 \\
4,800 \\
3,800\end{array}$ & $\begin{array}{l}3,600 \\
2,600 \\
3,700\end{array}$ \\
\hline GS-4A & $4 \mathrm{G} 4 \mathrm{~A}$ & $\begin{array}{l}4-16-92 \\
4-16-92\end{array}$ & $\begin{array}{l}2.7 \\
2.7\end{array}$ & $\begin{array}{l}1,400 \\
1,500\end{array}$ & $\begin{array}{l}8.1 \\
9.2\end{array}$ & $\begin{array}{r}<.10 \\
.10\end{array}$ & $\begin{array}{l}.26 \\
.27\end{array}$ & $\begin{array}{l}42 \\
42\end{array}$ & $\begin{array}{l}2,320 \\
2,340\end{array}$ & $\begin{array}{l}40 \\
50\end{array}$ & $\begin{array}{l}1,100 \\
1,000\end{array}$ \\
\hline GS-4B & 4G4B & $\begin{array}{r}1-31-92 \\
4-16-92 \\
12-15-92\end{array}$ & $\begin{array}{l}3.5 \\
2.8 \\
2.7\end{array}$ & $\begin{array}{l}2,100 \\
2,100 \\
2,300\end{array}$ & $\begin{array}{r}100 \\
54 \\
26\end{array}$ & $\begin{array}{l}.30 \\
.20 \\
.20\end{array}$ & $\begin{array}{l}4.6 \\
1.3 \\
.24\end{array}$ & $\begin{array}{l}33 \\
32 \\
37\end{array}$ & $\begin{array}{l}3,390 \\
3,190 \\
3,510\end{array}$ & $\begin{array}{r}<10 \\
20 \\
60\end{array}$ & $\begin{array}{l}630 \\
530 \\
900\end{array}$ \\
\hline GS-4C & $4 G 4 C$ & $\begin{array}{l}2-03-92 \\
4-18-92\end{array}$ & $\begin{array}{l}4.9 \\
7.6\end{array}$ & $\begin{array}{l}2,000 \\
2,200\end{array}$ & $\begin{array}{r}93 \\
320\end{array}$ & $\begin{array}{l}.80 \\
.30\end{array}$ & $\begin{array}{l}5.7 \\
1.3\end{array}$ & $\begin{array}{l}30 \\
22\end{array}$ & $\begin{array}{l}3,410 \\
3,870\end{array}$ & $\begin{array}{r}<10 \\
30\end{array}$ & $\begin{array}{l}670 \\
520\end{array}$ \\
\hline GS-5 & 4G5 & $\begin{array}{r}1-27-92 \\
4-13-92 \\
12-18-92\end{array}$ & $\begin{array}{l}7.0 \\
6.4 \\
6.3\end{array}$ & $\begin{array}{l}1,400 \\
2,900 \\
2,900\end{array}$ & $\begin{array}{l}15 \\
16 \\
25\end{array}$ & $\begin{array}{l}.80 \\
.20 \\
.30\end{array}$ & $\begin{array}{l}.28 \\
.22 \\
.13\end{array}$ & $\begin{array}{l}22 \\
41 \\
44\end{array}$ & $\begin{array}{l}1,970 \\
3,840 \\
4,320\end{array}$ & $\begin{array}{r}270 \\
240 \\
3,800\end{array}$ & $\begin{array}{l}2,900 \\
3,000 \\
2,900\end{array}$ \\
\hline GS-6 & $4 \mathrm{G} 6$ & $\begin{array}{l}1-29-92^{2} \\
1-29-92^{3} \\
4-15-92^{4} \\
4-15-92^{4}\end{array}$ & $\begin{array}{l}13 \\
17 \\
19 \\
20\end{array}$ & $\begin{array}{l}4,400 \\
4,800 \\
4,000 \\
2,900\end{array}$ & $\begin{array}{l}1,800 \\
2,800 \\
4,100 \\
5,000\end{array}$ & $\begin{array}{l}3.5 \\
6.5 \\
2.8 \\
3.2\end{array}$ & $\begin{array}{c}13 \\
5.1 \\
8.3 \\
6.5\end{array}$ & $\begin{array}{l}43 \\
38 \\
34 \\
35\end{array}$ & $\begin{array}{l}11,000 \\
12,400 \\
15,000 \\
14,500\end{array}$ & $\begin{array}{l}37,000 \\
63,000 \\
52,000 \\
51,000\end{array}$ & $\begin{array}{r}1,200 \\
1,000 \\
680 \\
690\end{array}$ \\
\hline GS-7 & $4 \mathrm{G} 7$ & $\begin{array}{l}1-28-92 \\
4-14-92\end{array}$ & $\begin{array}{l}3.7 \\
3.1\end{array}$ & $\begin{array}{l}2,300 \\
1,700\end{array}$ & $\begin{array}{l}27 \\
20\end{array}$ & $\begin{array}{c}1.5 \\
.80\end{array}$ & $\begin{array}{l}.50 \\
.39\end{array}$ & $\begin{array}{l}51 \\
38\end{array}$ & $\begin{array}{l}3,620 \\
2,610\end{array}$ & $\begin{array}{l}9,100 \\
3,600\end{array}$ & $\begin{array}{l}970 \\
630\end{array}$ \\
\hline GS-8A & $4 \mathrm{G} 8 \mathrm{~A}$ & $\begin{array}{r}1-31-92 \\
4-14-92 \\
12-04-92\end{array}$ & $\begin{array}{l}2.7 \\
2.6 \\
2.3\end{array}$ & $\begin{array}{l}5,400 \\
5,900 \\
5,700\end{array}$ & $\begin{array}{l}20 \\
60 \\
51\end{array}$ & $\begin{array}{l}2.0 \\
9.8 \\
4.8\end{array}$ & $\begin{array}{l}.31 \\
.32 \\
.48\end{array}$ & $\begin{array}{l}100 \\
110 \\
120\end{array}$ & $\begin{array}{l}8,470 \\
9,020 \\
8,670\end{array}$ & $\begin{array}{l}240,000 \\
220,000 \\
250,000\end{array}$ & $\begin{array}{l}1,600 \\
1,400 \\
1,500\end{array}$ \\
\hline GS-8B & 4G8B & $\begin{array}{l}2-03-92 \\
4-17-92\end{array}$ & $\begin{array}{l}6.5 \\
9.1\end{array}$ & $\begin{array}{l}4,500 \\
4,400\end{array}$ & $\begin{array}{l}320 \\
290\end{array}$ & $\begin{array}{l}3.5 \\
6.4\end{array}$ & $\begin{array}{l}3.4 \\
3.9\end{array}$ & $\begin{array}{l}60 \\
48\end{array}$ & $\begin{array}{l}7,700 \\
7,530\end{array}$ & $\begin{array}{l}81,000 \\
89,000\end{array}$ & $\begin{array}{r}1,200 \\
970\end{array}$ \\
\hline MRR-A & & $12-22-92$ & $<.10$ & 8,500 & 38 & .40 & 1.9 & 190 & 13,200 & 720,000 & 1,700 \\
\hline MRR-A ${ }^{6}$ & & $12-22-92$ & 1.4 & 4,800 & 22 & .90 & .94 & 130 & 3,820 & 280,000 & 940 \\
\hline MRR-B ${ }^{5}$ & & $12-22-92$ & -- & -- & - & - & -- & - & -- & -- & -- \\
\hline
\end{tabular}

Footnotes at end of table. 
Table 3. Water-quality data for Mine Run Reservoir and wells at the Penn Mine-Continued

\begin{tabular}{|c|c|c|c|c|c|c|c|c|c|c|}
\hline $\begin{array}{l}\text { Well } \\
\text { name }\end{array}$ & $\begin{array}{l}\text { State } \\
\text { well } \\
\text { No. }\end{array}$ & Date & $\begin{array}{l}\text { Copper, } \\
\text { dis- } \\
\text { solved } \\
(\mu \mathrm{g} / \mathrm{L})\end{array}$ & $\begin{array}{l}\text { Iron, } \\
\text { dis- } \\
\text { solved } \\
(\mu \mathrm{g} / \mathrm{L})\end{array}$ & $\begin{array}{l}\text { Lead, } \\
\text { dis- } \\
\text { solved } \\
(\mu \mathrm{g} / \mathrm{L})\end{array}$ & $\begin{array}{l}\text { Manga- } \\
\text { nese, } \\
\text { dis- } \\
\text { solved } \\
(\mu \mathrm{g} / \mathrm{L})\end{array}$ & $\begin{array}{c}\text { Silver, } \\
\text { dis- } \\
\text { solved } \\
(\mu \mathrm{g} / \mathrm{L})\end{array}$ & $\begin{array}{l}\text { Zinc, } \\
\text { dis- } \\
\text { solved } \\
(\mu \mathrm{g} / \mathrm{L})\end{array}$ & $\begin{array}{l}\delta \mathrm{D} \\
\text { (per } \\
\text { mil) }\end{array}$ & $\begin{array}{l}\delta^{18} \mathrm{O} \\
\text { (per } \\
\text { mil) }\end{array}$ \\
\hline GS-1A & 4G1A & $\begin{array}{r}1-29-92 \\
4-17-92 \\
12-15-92\end{array}$ & $\begin{array}{r}3,000 \\
9,800 \\
13,000\end{array}$ & $\begin{array}{r}150 \\
160 \\
1,900\end{array}$ & $\begin{array}{l}<1 \\
<1 \\
<1\end{array}$ & $\begin{array}{l}24,000 \\
27,000 \\
33,000\end{array}$ & $\begin{array}{l}<1.0 \\
<1.0 \\
<1.0\end{array}$ & $\begin{array}{l}110,000 \\
140,000 \\
190,000\end{array}$ & $\begin{array}{l}-36.5 \\
-37.4\end{array}$ & $\begin{array}{l}-\overline{-3.40} \\
-3.31\end{array}$ \\
\hline GS-1B & $4 \mathrm{G} 1 \mathrm{~B}$ & $\begin{array}{l}2-03-92 \\
4-18-92\end{array}$ & $\begin{array}{r}2,400 \\
<10\end{array}$ & $\begin{array}{r}30 \\
<10\end{array}$ & $\begin{array}{r}2 \\
<1\end{array}$ & $\begin{array}{l}24,000 \\
20,000\end{array}$ & $\begin{array}{l}<1.0 \\
<1.0\end{array}$ & $\begin{array}{l}83,000 \\
18,000\end{array}$ & $-\overline{40.0}$ & $-\overline{-3.85}$ \\
\hline GS-2 & $4 \mathrm{G} 2$ & $\begin{array}{l}1-28-92 \\
4-14-92\end{array}$ & $\begin{array}{l}<10 \\
<10\end{array}$ & $\begin{array}{r}5 \\
<10\end{array}$ & $\begin{array}{l}<1 \\
<1\end{array}$ & $\begin{array}{l}75 \\
70\end{array}$ & $\begin{array}{l}<1.0 \\
<1.0\end{array}$ & $\begin{array}{l}47 \\
20\end{array}$ & $\overline{-56.0}$ & $-\overline{-7.65}$ \\
\hline GS-3 & $4 \mathrm{G} 3$ & $\begin{array}{r}1-30-92 \\
4-15-92 \\
12-19-92\end{array}$ & $\begin{array}{l}15,000 \\
12,000 \\
11,000\end{array}$ & $\begin{array}{l}60 \\
60 \\
80\end{array}$ & $\begin{array}{l}<1 \\
<1 \\
<1\end{array}$ & $\begin{array}{l}29,000 \\
25,000 \\
38,000\end{array}$ & $\begin{array}{l}<1.0 \\
<1.0 \\
<1.0\end{array}$ & $\begin{array}{r}170,000 \\
-\overline{2}\end{array}$ & $\begin{array}{l}-- \\
-35.0 \\
-32.1\end{array}$ & $\begin{array}{l}-\overline{-} \\
-3.45 \\
-2.32\end{array}$ \\
\hline GS-4A & $4 \mathrm{G} 4 \mathrm{~A}$ & $\begin{array}{l}4-16-92 \\
4-16-92\end{array}$ & $\begin{array}{l}1,100 \\
1,100\end{array}$ & $\begin{array}{l}<10 \\
<10\end{array}$ & $\begin{array}{l}<1 \\
<1\end{array}$ & $\begin{array}{l}980 \\
850\end{array}$ & $\begin{array}{l}<1.0 \\
<1.0\end{array}$ & $\begin{array}{l}39,000 \\
34,000\end{array}$ & $\begin{array}{l}-51.5 \\
-50.0\end{array}$ & $\begin{array}{l}-6.60 \\
-6.65\end{array}$ \\
\hline GS-4B & 4G04B & $\begin{array}{r}1-31-92 \\
4-16-92 \\
12-15-92\end{array}$ & $\begin{array}{l}160 \\
130 \\
400\end{array}$ & $\begin{array}{l}30 \\
20 \\
10\end{array}$ & $\begin{array}{r}4 \\
<1 \\
<1\end{array}$ & $\begin{array}{l}480 \\
260 \\
120\end{array}$ & $\begin{array}{l}<1.0 \\
<1.0 \\
<1.0\end{array}$ & $\begin{array}{l}16,000 \\
12,000 \\
26,000\end{array}$ & $\begin{array}{l}-- \\
-48.5 \\
-46.5\end{array}$ & $\begin{array}{l}-6.30 \\
-6.01\end{array}$ \\
\hline GS-4C & $4 \mathrm{G} 4 \mathrm{C}$ & $\begin{array}{l}2-03-92 \\
4-18-92\end{array}$ & $\begin{array}{r}230 \\
30\end{array}$ & $\begin{array}{r}10 \\
<10\end{array}$ & $\begin{array}{l}<1 \\
<1\end{array}$ & $\begin{array}{l}690 \\
790\end{array}$ & $\begin{array}{l}<1.0 \\
<1.0\end{array}$ & $\begin{array}{r}17,000 \\
--\end{array}$ & -48.5 & $-\overline{-6.25}$ \\
\hline GS-5 & $4 \mathrm{G} 5$ & $\begin{array}{r}1-27-92 \\
4-13-92 \\
12-18-92\end{array}$ & $\begin{array}{l}2,500 \\
2,600 \\
6,100\end{array}$ & $\begin{array}{r}190 \\
130 \\
3,200\end{array}$ & $\begin{array}{l}<1 \\
<1 \\
<1\end{array}$ & $\begin{array}{l}1,900 \\
1,900 \\
4,600\end{array}$ & $\begin{array}{l}<1.0 \\
<1.0 \\
<1.0\end{array}$ & $\begin{array}{l}72,000 \\
78,000 \\
94,000\end{array}$ & $\begin{array}{l}-46.5 \\
-42.9\end{array}$ & $\begin{array}{l}- \\
-5.40 \\
-5.04\end{array}$ \\
\hline GS-6 & $4 \mathrm{G} 6$ & $\begin{array}{l}1-29-92^{2} \\
1-29-92^{3} \\
4-15-92^{4} \\
4-15-92^{4}\end{array}$ & $\begin{array}{r}4,000 \\
70 \\
12,000 \\
13,000\end{array}$ & $\begin{array}{r}240,000 \\
220,000 \\
930 \\
950\end{array}$ & $\begin{array}{r}24 \\
18 \\
4 \\
4\end{array}$ & $\begin{array}{l}33,000 \\
27,000 \\
24,000 \\
25,000\end{array}$ & $\begin{array}{l}<1.0 \\
<1.0 \\
<1.0 \\
<1.0\end{array}$ & $\begin{array}{l}310,000 \\
290,000 \\
120,000 \\
170,000\end{array}$ & $\begin{array}{c}- \\
- \\
-35.0 \\
-33.0\end{array}$ & $\begin{array}{l}-- \\
-- \\
-2.90 \\
-2.90\end{array}$ \\
\hline GS-7 & $4 \mathrm{G} 7$ & $\begin{array}{l}1-28-92 \\
4-14-92\end{array}$ & $\begin{array}{l}21,000 \\
14,000\end{array}$ & $\begin{array}{r}1,200 \\
100\end{array}$ & $\begin{array}{l}<1 \\
<1\end{array}$ & $\begin{array}{l}29,000 \\
23,000\end{array}$ & $\begin{array}{l}<1.0 \\
<1.0\end{array}$ & $\begin{array}{r}150,000 \\
83,000\end{array}$ & $-\overline{-58.0}$ & $-\overline{-8.20}$ \\
\hline GS-8A & $4 \mathrm{G} 8 \mathrm{~A}$ & $\begin{array}{r}1-31-92 \\
4-14-92 \\
12-04-92\end{array}$ & $\begin{array}{l}84,000 \\
86,000 \\
88,000\end{array}$ & $\begin{array}{l}120,000 \\
110,000 \\
150,000\end{array}$ & $\begin{array}{l}<1 \\
<1 \\
<1\end{array}$ & $\begin{array}{l}52,000 \\
58,000 \\
52,000\end{array}$ & $\begin{array}{l}<1.0 \\
<1.0 \\
<1.0\end{array}$ & $\begin{array}{r}430,000 \\
-- \\
470,000\end{array}$ & $\begin{array}{l}-. . \\
-32.5 \\
-33.9\end{array}$ & $\begin{array}{l}- \\
-2.65 \\
-2.61\end{array}$ \\
\hline GS-8B & $4 \mathrm{G} 8 \mathrm{~B}$ & $\begin{array}{l}2-03-92 \\
4-17-92\end{array}$ & $\begin{array}{r}10,000 \\
5,400\end{array}$ & $\begin{array}{l}88,000 \\
94,000\end{array}$ & $\begin{array}{r}18 \\
7\end{array}$ & $\begin{array}{l}44,000 \\
44,000\end{array}$ & $\begin{array}{l}<1.0 \\
<1.0\end{array}$ & $\begin{array}{l}300,000 \\
300,000\end{array}$ & -38.0 & $\overline{-3.85}$ \\
\hline MRR-A ${ }^{5}$ & & $12-22-92$ & 110,000 & 160,000 & $<1$ & 51,000 & $<1.0$ & 570,000 & -8.4 & 2.55 \\
\hline MRR-A ${ }^{6}$ & & $12-22-92$ & 62,000 & 110,000 & 7 & 28,000 & $<1.0$ & 200,000 & -25.4 & -2.12 \\
\hline MRR-B ${ }^{5}$ & & $12-22-92$ & - & -- & - & - & - & - & -3.6 & 3.78 \\
\hline
\end{tabular}

${ }^{1}$ Redox potential relative to the standard hydrogen electrode potential $(\mathrm{Eh})$, measured using a platinum electrode with quinhydrone standard redox buffers, as described by Makita and Fujii (1992).

${ }^{2}$ Sample collected at depth of 50 feet.

${ }^{3}$ Sample collected at depth of 160 feet.

${ }^{4}$ Replicate samples collected at depth of 90 feet.

${ }^{5}$ Six feet below water surface.

${ }^{6}$ One foot below water surface. 
for upper intervals of open boreholes may contain water derived from the underlying slate unit. The purge logs (appendix 3 ) indicate that more than three well volumes were purged from two of the more permeable intervals (GS-4B and $-8 \mathrm{~A}$ ) and that more than one well volume was purged for several others. Deep intervals and open boreholes generally yielded less than one well volume during purging in response to slow recovery of water levels and low pumping rates (appendix 3). In all cases, the field properties $(\mathrm{pH}$, specific conductance, temperature, and redox potential) had stabilized in the flow-through cell prior to sampling.

Preliminary sampling done in December 1991 showed the effects of materials introduced to the wells during vandalism in November 1991 and the subsequent airlifting to clean and purge the wells. Aeration of well water can change water quality, particularly elements (for example, iron) involved in redox reactions. Data from sampling in December 1991 are not shown in table 3 because they are less representative of water-quality properties prior to drilling when compared with subsequent samples. Specific conductance in December 1991 ranged from $1,860 \mu \mathrm{S} / \mathrm{cm}$ (microsiemens per centimeter at $25^{\circ} \mathrm{C}$ ) at well GS-2 (60-foot depth below land surface) to $12,400 \mu \mathrm{S} / \mathrm{cm}$ at well GS-6 (280-foot depth below land surface). The $\mathrm{pH}$ of purged water ranged from 4.6 at well GS-8 (160-foot depth below land surface) to 8.9 at GS-3 (145 ft below land surface). The high pH value at GS-3 resulted from the presence of cement (dry mortar mix) poured into the well during vandalism. Temperatures ranged from $12.5^{\circ} \mathrm{C}$ at well GS-2 to $23.5^{\circ} \mathrm{C}$ at well GS-7. Relatively high concentrations of dissolved bromide in several wells indicated the presence of water used during drilling and injection tests. The introduced waters were spiked with sodium bromide to yield a bromide concentration of about $100 \mathrm{mg} / \mathrm{L}$. Bromide concentration was highest $(15 \mathrm{mg} / \mathrm{L})$ in water from well GS-2.

The samples collected during January-February 1992 represent conditions closer to natural ground water than the December 1991 samples. The JanuaryFebruary 1992 samples were collected using a submersible pump. Multiple intervals were sampled at sites equipped with inflatable packers (GS-1, -4, and -8). Specific conductance ranged from 1,430 $\mu \mathrm{S} / \mathrm{cm}$ at well GS-2 to $14,000 \mu \mathrm{S} / \mathrm{cm}$ at well GS-6. The $\mathrm{pH}$ of ground water ranged from 3.7 at well GS-8A to 7.6 at well GS-2. Water temperature ranged between $16.0^{\circ} \mathrm{C}$ at well GS-4B to $19.5^{\circ} \mathrm{C}$ at well GS-3 (table 3).
Analytical results from sampling during April 1992 provide the most comprehensive available representation of ground-water quality. Values for specific conductance ranged from $1,810 \mu \mathrm{S} / \mathrm{cm}$ at well GS-2 to $18,000 \mu \mathrm{S} / \mathrm{cm}$ at well GS-6. The $\mathrm{pH}$ of sampled water ranged from 3.7 at well GS-8A to 7.8 at well GS-2. Water temperatures ranged from $17.5^{\circ} \mathrm{C}$ at well GS-5 to $19.5^{\circ} \mathrm{C}$ at well GS-3. The results of stable-isotope analysis indicate that ground water has been evaporated to a variable degree (table 3 ). These results are discussed later in this section. As part of the quality-control program, a field equipment blank was run through the sampling process, including filtration and preservation. Nearly all properties determined in the field blank were less than detection limits. Calcium, magnesium, chloride, and iron were present at concentrations near their detection limits.

Comparison of water-quality data for April and December 1992 (table 3) indicates transient behavior consistent with a mobile contaminant plume. Water from all wells measured during these months (GS-1A, $-3,-4 A,-5$, and $-8 A$ ) showed an increase in specific conductance. During the same period, water from three of five wells showed a decrease in $\mathrm{pH}$ and an increase in dissolved copper concentration. Rising specific conductance and copper and falling pH reflect a higher proportion of acid drainage in ground water. These data and the data on water levels (table 2; fig. 6) are consistent with the interpretation that a plume of acid drainage in ground water in the vicinity of wells GS-1 and GS-3 was migrating toward Camanche Reservoir during this period. Water-level data for wells GS-4A, -5 , and $-8 \mathrm{~A}$ indicate that hydraulic heads in these three wells are very close to the altitude of the surface of Camanche Reservoir, making interpretation of water-quality trends for these wells more difficult. More data are needed for water levels and water quality for these wells to interpret the transient behavior of the contaminated plume in that area.

\section{GENERATION OF ACID MINE DRAINAGE}

Oxidation of sulfide minerals produces low values of $\mathrm{pH}$ in water draining or pumped from many coal and metal mines (Hem, 1985). The volume of acid mine drainage can be large and may continue long after mining operations have ceased. Typical characteristics of acid mine drainage include low $\mathrm{pH}$ and high concentrations of iron, aluminum, and sulfate (Todd, 1980). Pyrite generally is slow to oxidize below the water table in circum-neutral waters with low concentrations of dissolved oxygen and ferric iron. However, exposure of pyrite to air and water 
produces sulfuric acid solutions that readily dissolve base-metal sulfides and other minerals. The complete oxidation of pyrite at near-neutral to weakly acid ( $\mathrm{pH}$ 4 to 7) conditions can be summarized by the following reaction (Alpers and Nordstrom, 1991):

$$
\begin{gathered}
\mathrm{FeS}_{2}+15 / 4 \mathrm{O}_{2}+7 / 2 \mathrm{H}_{2} \mathrm{O} \rightarrow \mathrm{Fe}^{\mathrm{II}}(\mathrm{OH})_{3(\mathrm{~s})} \\
+2(\mathrm{SO})_{4}^{2-}+4(\mathrm{H})^{+} .
\end{gathered}
$$

At $\mathrm{pH}$ values less than 4 , ferric iron can act as the direct oxidant of pyrite:

$$
\mathrm{FeS}_{2}+14 \mathrm{Fe}^{3+}+8 \mathrm{H}_{2} \mathrm{O} \rightarrow 15 \mathrm{Fe}^{2+}+2 \mathrm{SO}_{4}^{2-}+16 \mathrm{H}^{+} .
$$

The latter reaction (equation 4) is fast (McKibben and Barnes, 1986), but its rate is limited in an abiotic system because the reoxidation of iron from ferrous to ferric by oxygen is extremely slow at $\mathrm{pH}$ values less than 4. However, the catalytic effect of the ironoxidizing bacterium Thiobacillus ferrooxidans speeds up the rate of the reaction

$$
\mathrm{Fe}^{2+}+1 / 4 \mathrm{O}_{2}+\mathrm{H}^{+} \rightarrow \mathrm{Fe}^{3+}+1 / 2 \mathrm{H}_{2} \mathrm{O}
$$

by five to six orders of magnitude over the abiotic rate (Nordstrom, 1985). The rate of regeneration of ferric iron (equation 5) is about three orders of magnitude greater than the rate of pyrite oxidation by ferric iron (equation 4). In the presence of abundant bacteria, equation 4 is the rate-determining step in the production of acid mine drainage (Singer and Stumm, 1970). Combining equations 4 and 5 , an acidic ferrous-sulfate solution is produced by the oxidation of pyrite according to the reaction

$$
\mathrm{FeS}_{2}+7 / 2 \mathrm{O}_{2}+\mathrm{H}_{2} \mathrm{O} \rightarrow \mathrm{Fe}^{2+}+2 \mathrm{SO}_{4}^{2-}+2 \mathrm{H}^{+} \text {. }
$$

The resulting acidic solution will attack other metalsulfide minerals, such as chalcopyrite and sphalerite. Percolation of acid mine drainage to ground water will lower $\mathrm{pH}$ and raise concentrations of metals and sulfate. Metals with elevated concentrations in ground water and surface water at the Penn Mine include aluminum, cadmium, copper, iron, and zinc. These dissolved constituents most probably are derived from oxidation of sulfide minerals and dissolution of associated aluminosilicate minerals in waste-rock piles exposed at several locations on the properties of New Penn Mines, Inc., and the Utility District (fig. 2). Another possible source of these constituents can be from dissolution of soluble sulfate minerals in the bedrock adjacent to the underground mine workings. In addition, the slag materials exposed near Camanche Reservoir contain high concentrations of zinc, which averaged 6.5 percent by weight in 8 bulk samples (Wiebelt and Ricker, 1948). Slag, when exposed to acid ground water, can be a source of metals, particularly zinc and cadmium.

Determinations of dissolved aluminum are complicated by its tendency to form particulate material (colloids) that pass through the standard filter membrane with $0.45-\mu \mathrm{m}$ pore diameter. Gibbsite $\left[\mathrm{Al}(\mathrm{OH})_{3}\right]$, for example, forms crystals that pass through standard filter media. The use of $0.10-\mu \mathrm{m}$ filters during sampling at the Penn Mine reduced the amount of colloidal aluminum in filtered samples. Water with $\mathrm{pH}$ values less than 4.5 can contain several hundred to several thousand milligrams of dissolved aluminum per liter (Hem, 1985; Nordstrom and Ball, 1986). At the Penn Mine, dissolved aluminum in ground water ranged from less than 0.010 to $250 \mathrm{mg} / \mathrm{L}$ (table 3 ).

Copper may be found in either the cuprous $\left(\mathrm{Cu}^{+}\right)$ or cupric $\left(\mathrm{Cu}^{2+}\right)$ oxidation state, but the cupric form is more common in near-surface waters. In solutions with alkaline $\mathrm{pH}$, copper hydroxycarbonates (for example, malachite) are slightly soluble and yield copper concentrations less than $10 \mu \mathrm{g} / \mathrm{L}$ (micrograms per liter) (Hem, 1977). Adsorption or coprecipitation of copper with hydrous ferric oxides can result in lower aqueous concentrations (Hem, 1977); however, this process is unlikely to occur to a significant degree in water with $\mathrm{pH}$ values less than 5 (Webster and others, 1994). Copper may be present in concentrations up to a few hundred milligrams per liter in acid mine drainage (Hem, 1985). Values for dissolved copper in ground water from the Penn Mine ranged from less than 0.010 to $88 \mathrm{mg} / \mathrm{L}$ (table 3 ).

In aerated water, ferric iron $\left(\mathrm{Fe}^{3+}\right)$ concentrations are not expected to exceed a few micrograms per liter in the $\mathrm{pH}$ range 6.5 to 8.5 (Hem, 1985). Like aluminum, the solubility of ferric iron is low at circum-neutral $\mathrm{pH}$; higher reported concentrations of iron at circum-neutral $\mathrm{pH}$ probably result from colloidal iron passing through the filter membrane. High concentrations of dissolved ferrous iron $\left(\mathrm{Fe}^{2+}\right.$ ) can occur in circum-neutral ground water having a low redox state. Dissolved ferrous iron is the primary product of pyrite oxidation (equations 4 and 6). Subsequent oxidation of $\mathrm{Fe}^{2+}$ to $\mathrm{Fe}^{3+}$ will lead to precipitation of $\mathrm{Fe}$ (III)-bearing minerals, generally with lower solubility than $\mathrm{Fe}$ (II)-bearing minerals. The saturation state of ground-water samples from 
Penn Mine with respect to various iron minerals that can potentially control iron solubility is discussed in a later section. Concentrations of dissolved iron in ground water at the Penn Mine ranged from less than 0.010 to $240 \mathrm{mg} / \mathrm{L}$ (table 3). Davy Environmental (1993) found high concentrations of iron in ground-water samples from the bedrock adjacent to the impoundments above Mine Run Dam. These high concentrations can be attributed to acid mine drainage generated by the oxidation of pyrite and other sulfide minerals in the surrounding waste rock.

Zinc is found in the same general abundance in crustal rocks as copper (Hem, 1985). However, aqueous zinc has only one significant oxidation state, $\mathrm{Zn}^{2+}$, and tends to be somewhat more soluble than copper in water. Under neutral-to-alkaline conditions, the equilibrium concentration of zinc is expected to be less than $0.1 \mathrm{mg} / \mathrm{L}$ in most cases. Water affected by acid mine drainage generally contains substantially higher concentrations of zinc. Dissolved zinc in ground water from the Penn Mine ranged from 0.020 to $470 \mathrm{mg} / \mathrm{L}$ (table 3 ).

Cadmium is found with zinc in most crustal environments, including the sulfide minerals sphalerite and tetrahedrite-tennantite. The ratio of zinc to cadmium is commonly on the order of 50 to 500 in massive sulfide deposits and associated mine drainage (D.K. Nordstrom, oral commun., 1992). Dissolved concentrations of cadmium in ground-water samples from Penn Mine ranged from less than 0.010 to 3.7 $\mathrm{mg} / \mathrm{L}$ (table 3). Ratios of zinc to cadmium for the data in table 3 range from 11 to 335 with a median value of 69 .

\section{DISTRIBUTION OF ACID MINE DRAINAGE}

Several water-quality properties were contoured in cross-section and map views to delineate the extent of acid mine drainage in ground water at the Penn Mine. Distributions of aluminum, iron, sulfate, oxygen isotopes, and $\mathrm{pH}$ for the April 1992 sampling were evaluated in this manner. The vertical distribution of chloride also was evaluated. Along cross section $B-B^{\prime}$, the major constituents of acid mine drainage show similar distributions, indicating that the acid-mine-drainage plume in April 1992 was concentrated in the metavolcanic unit. The distribution of sulfate in borehole GS-4, however, shows slightly elevated sulfate concentration with depth, apparently the result of lateral migration of high sulfate water along the metavolcanic-slate contact (fig. 8). Sulfate concentration generally decreases with depth and decreases toward the northern and southern ends of section $B-B^{\prime}$ (fig. 8). The distribution of chloride shows the reverse trend and increases with depth (fig. 9). Within individual wells with multiple intervals separated by inflatable packers, chloride concentration was always highest in the underlying slate unit (fig. 9; table 3). In the 200-foot boreholes, chloride ranged from 93 to $570 \mathrm{mg} / \mathrm{L}$ in the slate intervals and from 8 to $100 \mathrm{mg} / \mathrm{L}$ in the metavolcanic rock intervals. The highest concentration of chloride, $5,000 \mathrm{mg} / \mathrm{L}$, was found in the 400 -foot borehole (GS-6), which penetrated more than $300 \mathrm{ft}$ of the slate unit. This indicates that the source of chloride is associated with the slate unit.

The distributions of major acid-minè-drainage constituents in map view are similar to the distribution of sulfate shown in figure 10. The acid mine drainage is derived from a source in or near the metavolcanic unit along the north abutment of Mine Run Dam. Most subsurface flow is in a northwesterly direction along the strike of the geologic contact (fig. 5) from the dam toward Camanche Reservoir. A component of flow to the southwest correlates with the interpreted fault (fig. 5) and the water-level contour map (fig. 7). Some of the acid mine drainage may preferentially follow the strike of this fault, which, apparently tends to have a high permeability along its strike in contrast to surrounding materials. In a study done by the Department of Energy in Tennessee, ground-water flow was found to follow. the geologic strike in a fractured bedrock aquifer (Lee and others, 1992). A tracer used in that study helped to determine that flow was controlled primarily by geologic strike and not by maximum hydraulic gradient. The highest concentrations of sulfate are associated with low values of $\mathrm{pH}$ (fig. 11). The plume also is delineated by lines of equal $\mathrm{pH}$ values in the ground water (fig. 12). Values for $\mathrm{pH}$ in most wells along the axis of the plume measured in December 1992 were lower than values in April 1992. This is consistent with the plume migrating downgradient toward Camanche Reservoir. The most acidic value recovered for $\mathrm{pH}$ in ground water in the study area is 3.7 (table 3). Values of $\mathrm{pH}$ in MineRun Reservoir, the inferred source region, range from 2.3 to 2.8 (Bond, 1988; Davy Environmental, 1993; this report, table 3 ).

Another way to delineate the extent of acid mine drainage in ground water is by the distribution of the stable isotopes deuterium [D or hydrogen-2 $\left.\left({ }^{2} \mathrm{H}\right)\right]$ and oxygen-18 $\left({ }^{18} \mathrm{O}\right)$. The most abundant isotopes that constitute the water molecule are ${ }^{18} \mathrm{O}$, oxygen- 16 $\left({ }^{16} \mathrm{O}\right),{ }^{2} \mathrm{H}$, and hydrogen- $1\left({ }^{1} \mathrm{H}\right)$. The heavy isotopes 


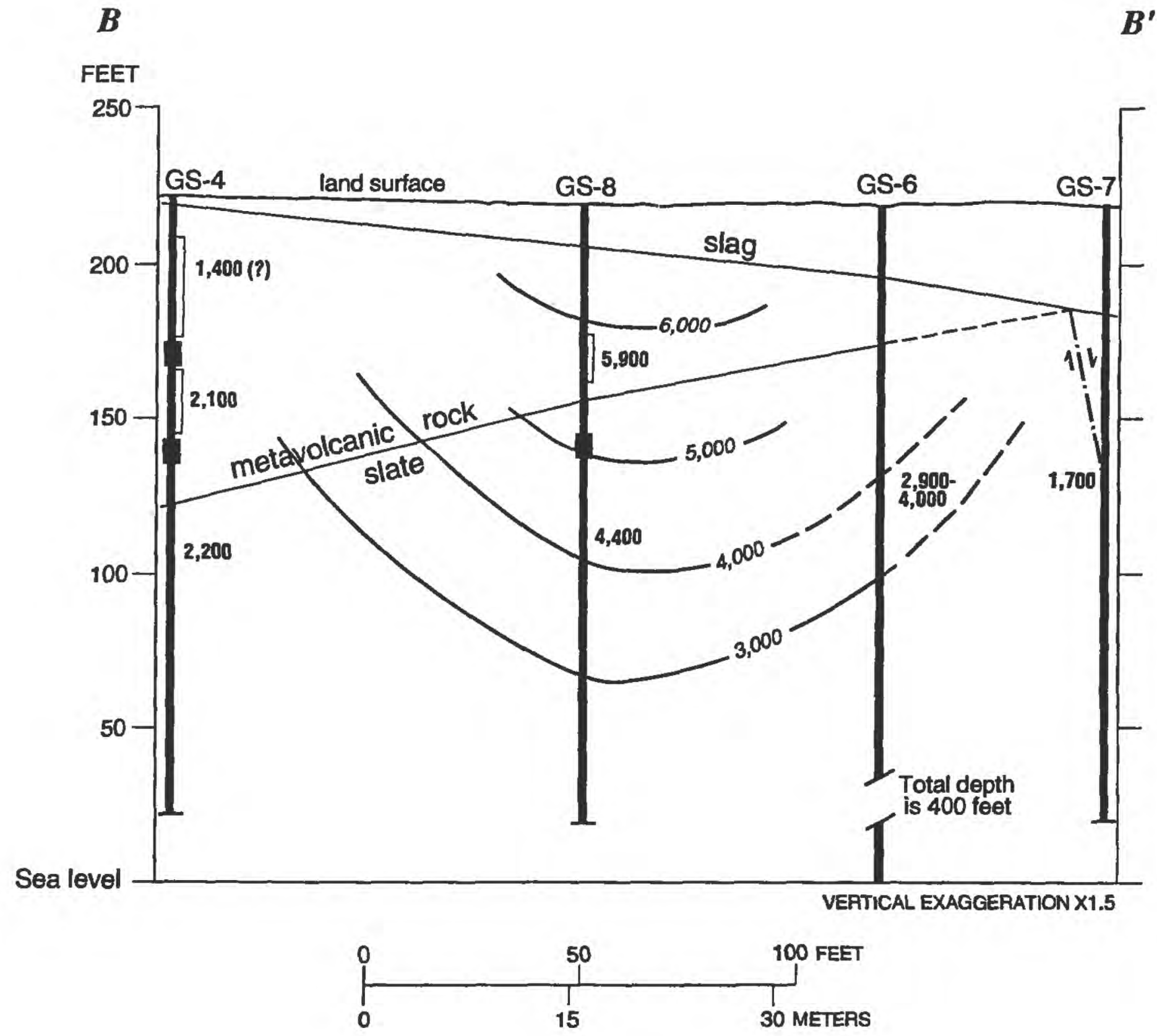

EXPLANATION

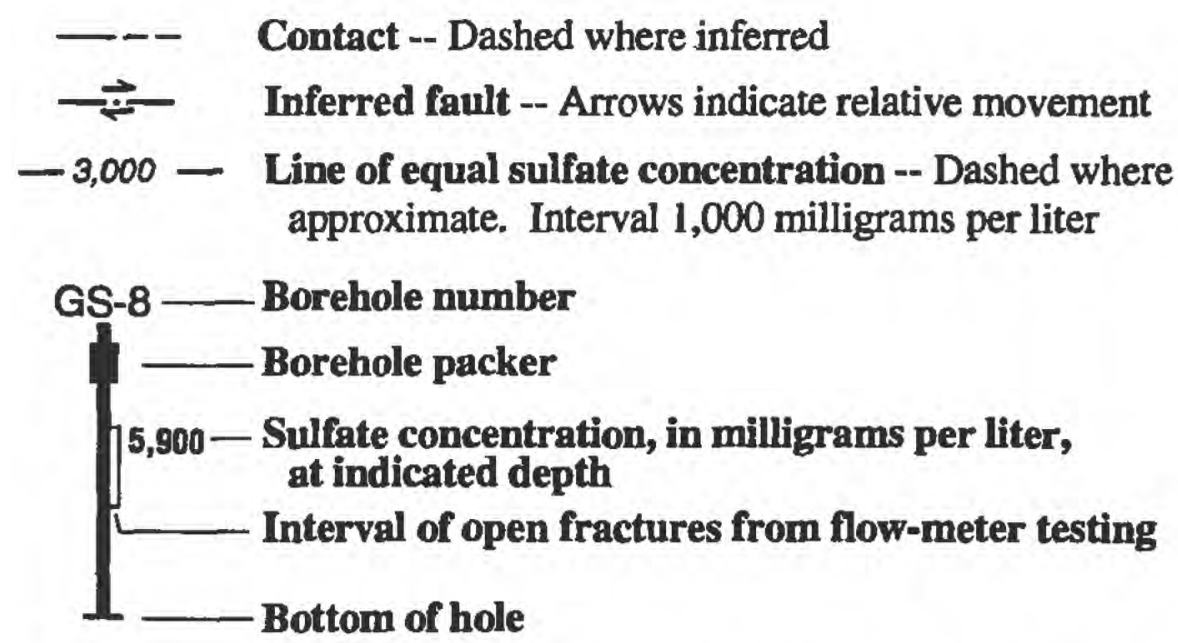

Figure 8. Distribution of sulfate with depth along geologic section B-B' at the Penn Mine, Aprill 1992.

${ }^{18} \mathrm{O}$ and ${ }^{2} \mathrm{H}$ exist naturally in average proportions of 0.2 percent of the oxygen and 0.07 percent of the hydrogen in water molecules. Ratios of the heavy to light isotopes, $R$, are expressed in delta units $(\delta)$, which are parts per thousand (per mille) differences relative to an arbitrary standard known as standard mean ocean water (V-SMOW) (O'Neill, 1986).

$$
\delta(\%)=\left[\left(R-R_{\mathrm{std}}\right) / R_{\mathrm{std}}\right] \times 1,000,
$$

where $R$ and $R_{\text {std }}$ are the isotope ratios $(\mathrm{D} / \mathrm{H}$ or ${ }^{18} \mathrm{O} /{ }^{16} \mathrm{O}$ ) of the sample and standard, respectively. Relative concentrations of ${ }^{2} \mathrm{H}$ and ${ }^{18} \mathrm{O}$, expressed as $\delta \mathrm{D}$ and $\delta^{18} \mathrm{O}$, generally correlate linearly. Graphic 


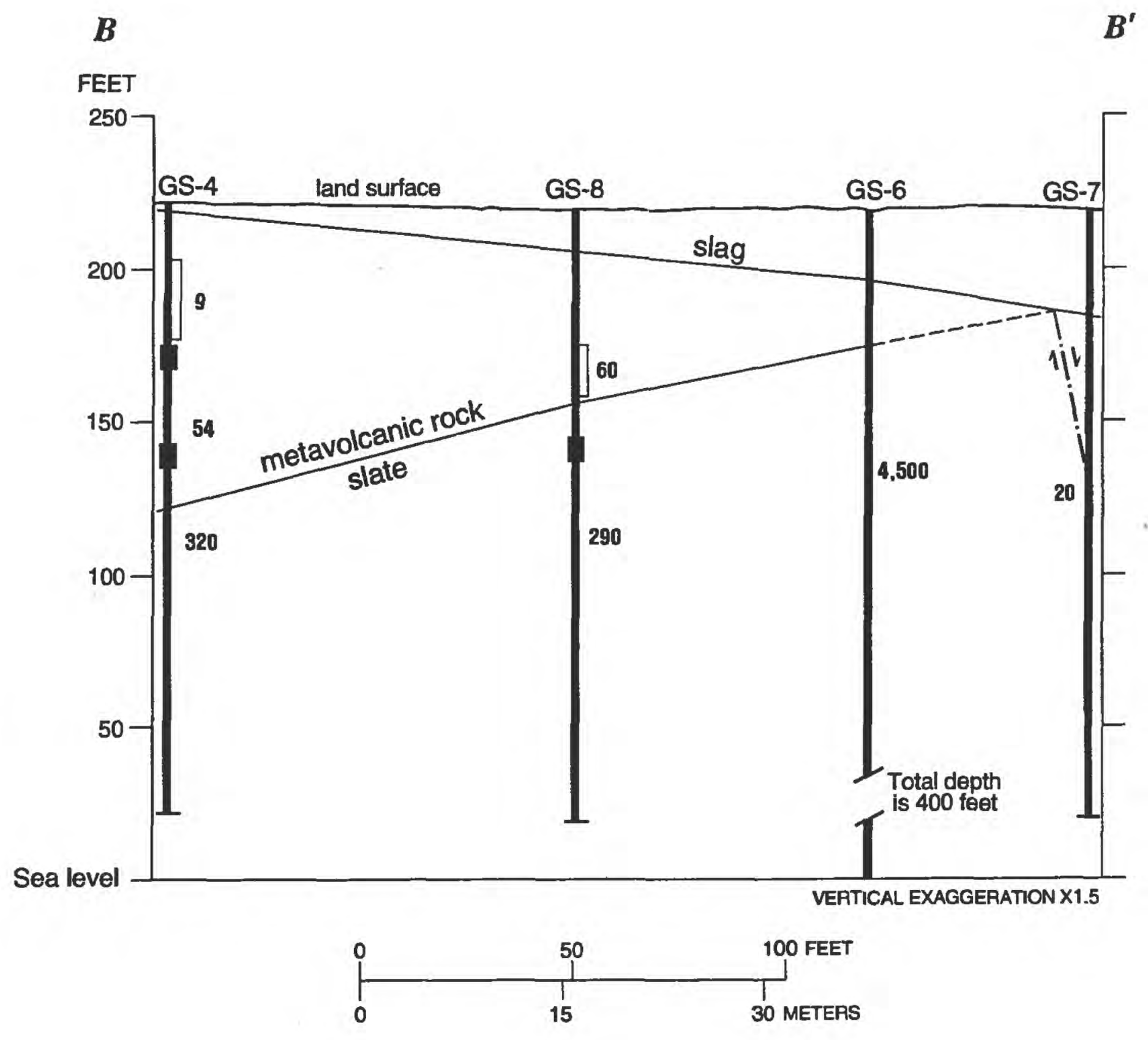

EXPLANATION

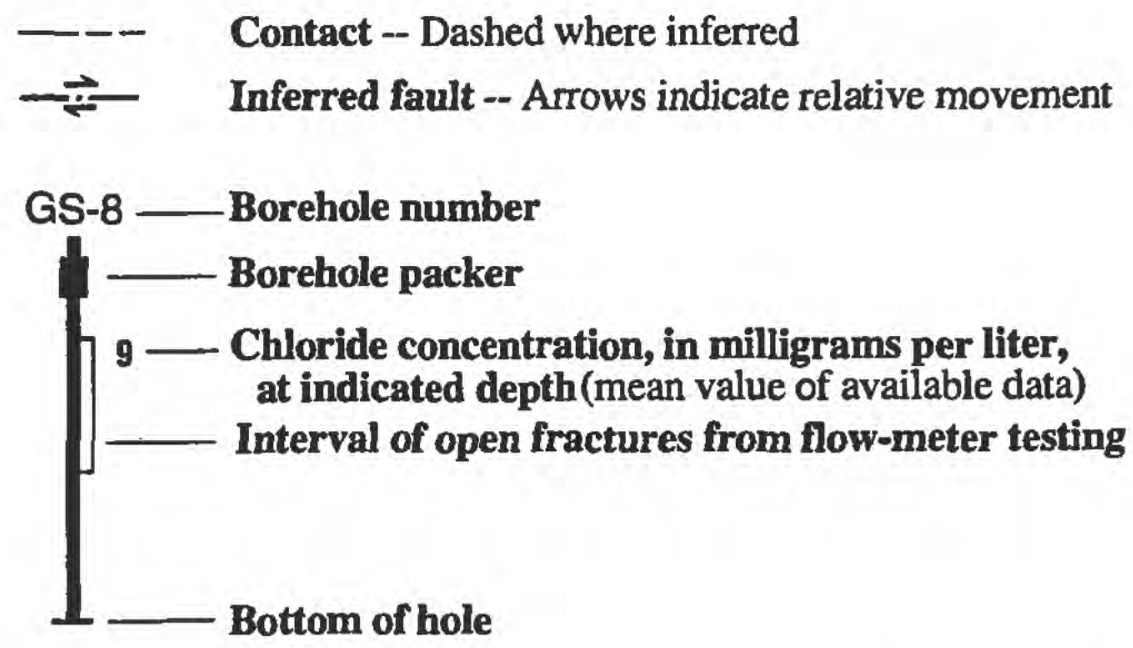

Figure 9. Distribution of chioride with depth aiong geoiogic section B- $B^{\prime}$ at the Penn Mine, April 1992.

representation of this relation for global precipitation data produces a straight line known as the meteoric water line, defined by

$$
\delta \mathrm{D}=8 \delta^{18} \mathrm{O}+10
$$

(Craig and others, 1963). 


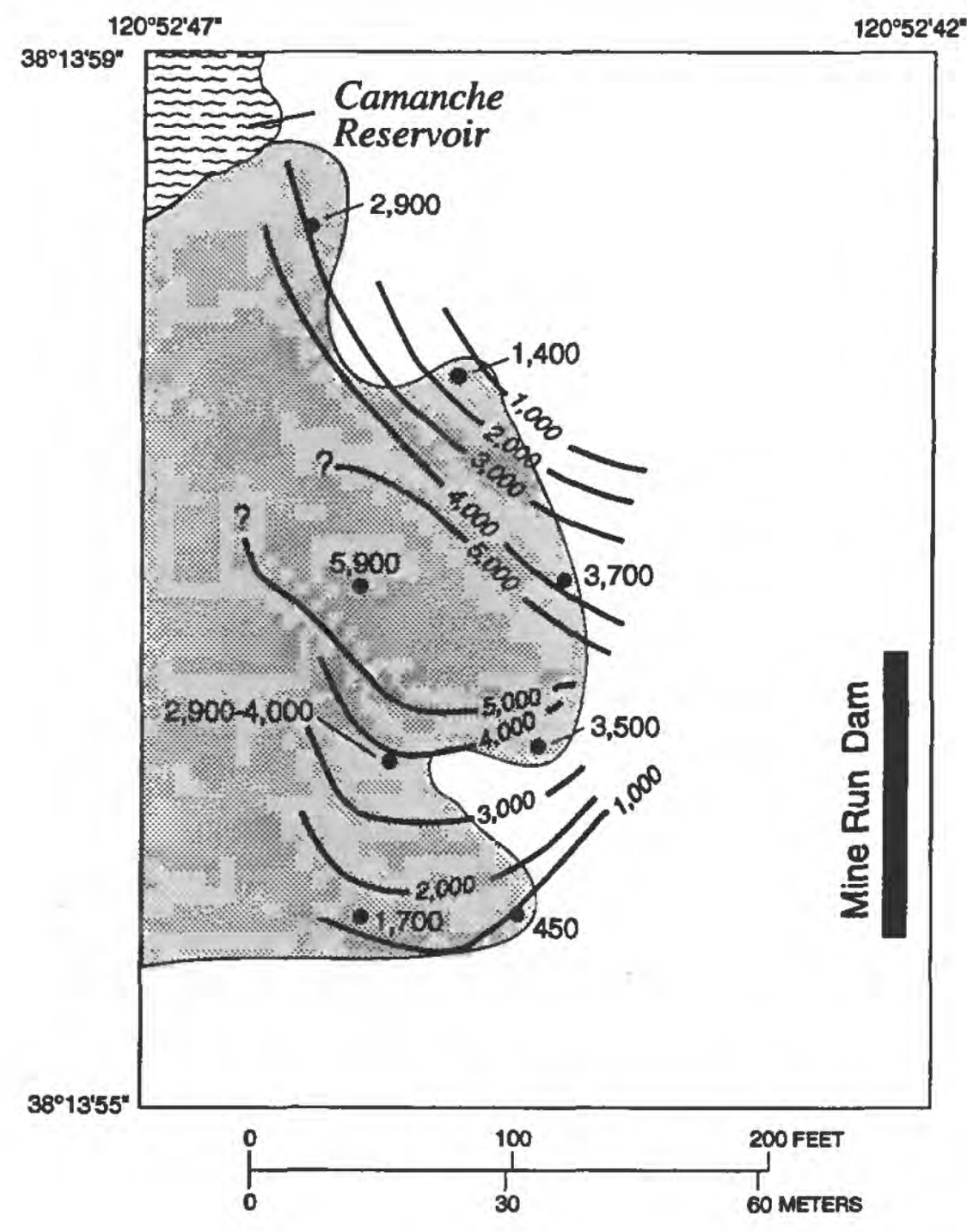

\section{EXPLANATION}

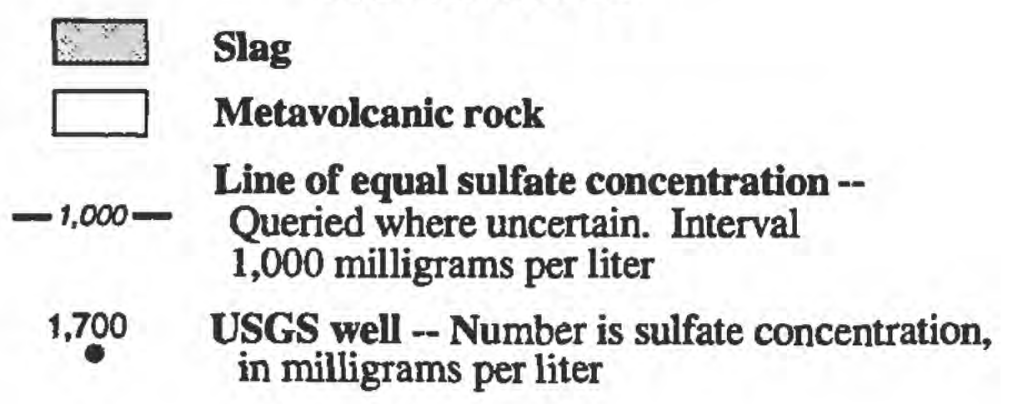

Figure 10. Distribution of sulfate in ground water at the Penn Mine, April 1992.

During the evaporation process, water molecules containing heavy isotopes tend to become concentrated in the residual water, whereas molecules containing lighter isotopes become enriched in the water vapor. Hence, isotopic values for bodies of surface water exposed to evaporation tend to be enriched in heavy isotopes relative to most ground water. The process of isotopic evaporative enrichment produces data that lie on a line with a slope between 3 and 6 on a plot of $\delta \mathrm{D}$ and $\delta^{18} \mathrm{O}$, to the right of the meteoric line (Craig and others, 1963).

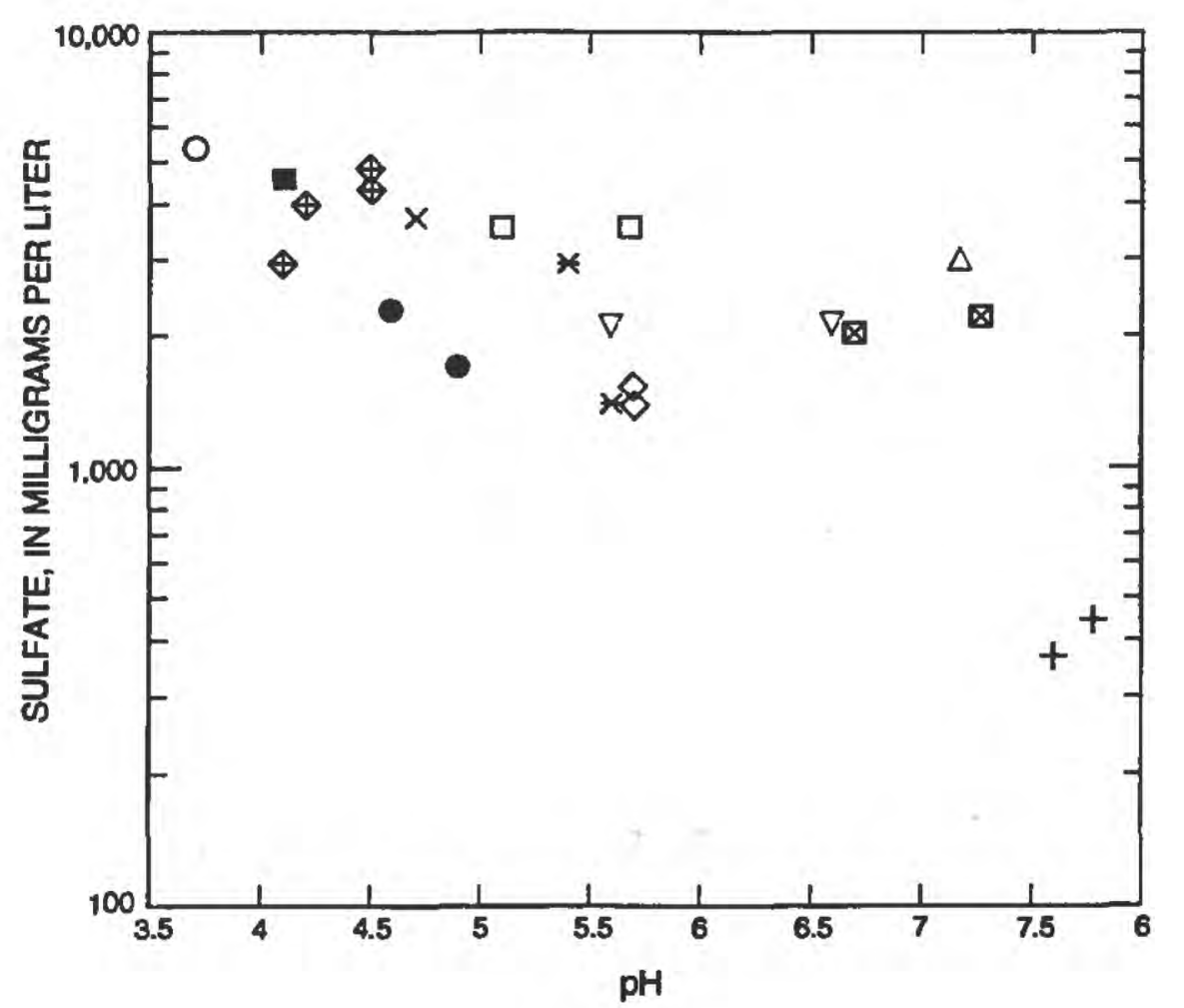

\begin{tabular}{|c|c|c|}
\hline \multicolumn{3}{|c|}{ EXPLANATION } \\
\hline GS-1A & $凶$ & GS- 4 C \\
\hline GS-1B & $*$ & GS-5 \\
\hline GS-2 & $\oplus$ & GS-6 \\
\hline GS-3 & - & GS-7 \\
\hline$G S-4 A$ & 0 & GS-8A \\
\hline GS-4B & $\mathbf{0}$ & GS-8B \\
\hline
\end{tabular}

Figure 11. Variation of sulfate concentration with $\mathrm{pH}$ in ground water from the Penn Mine, April 1992.

This phenomenon is observed in a plot of isotope data from ground water and Mine Run Reservoir at the Penn Mine (fig. 13). The data can be fit by leastsquares linear regression $\left(r^{2}=0.985\right)$, which gives a line described by the equation

$$
\delta D=4.4 \delta^{18} O-21 .
$$

The slope of this line indicates that the ground-water downgradient from Mine Run Dam represents the mixing of evaporated water from Mine Run Reservoir with nonevaporated ground water. This interpretation suggests that the source of dissolved metals and sulfate in the ground water is leakage from the unlined Mine Run Reservoir. Wells GS-2 and -7 show the least enrichment in heavy isotopes and exhibit the lowest levels of contamination by acid mine drainage. Samples from Mine Run Reservoir and wells GS-3, -6 and -8 A show the highest enrichment in heavy isotopes and highest levels of acidmine-drainage contamination. The aerial distribution of the evaporated ground-water plume is delineated by $\delta^{18} \mathrm{O}$ in figure 14. The stable-isotope composition of ground water probably results from mixing non- 


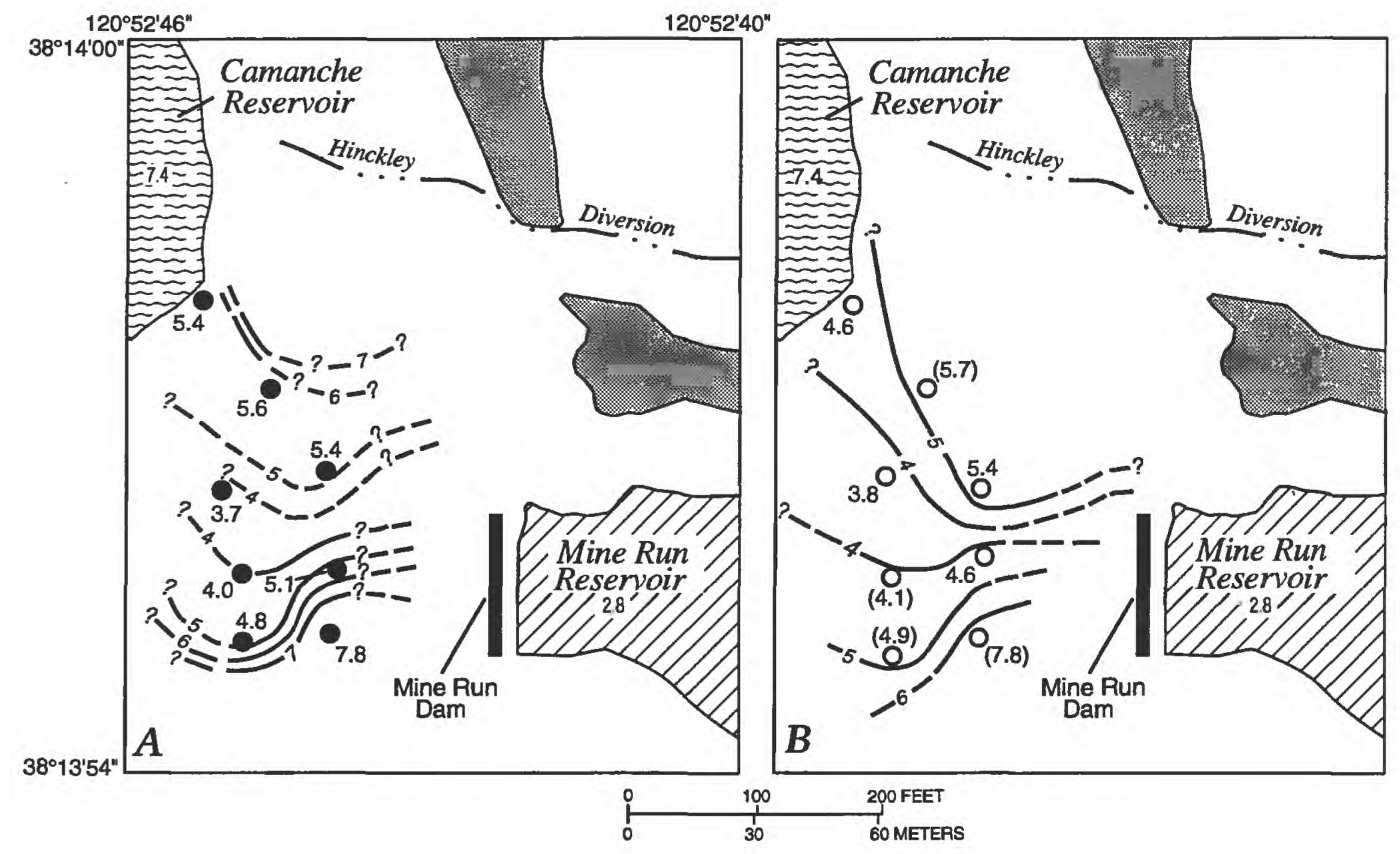

EXPLANATION

Waste rock
Wastewater impoundment
$\begin{aligned} & \text { Line of equal pH - Dashed where approx- } \\ & \text { imately located; queried where uncertain. } \\ & \text { Interval } 1 \text { unit }\end{aligned}$
$\begin{array}{ll}\text { USGS well -- Number is pH value April } 1992 \\ \text { US.9) }\end{array}$
$\begin{aligned} & \text { USG well -- Number is pH value December } \\ & \text { 1992. Parentheses indicate pH value prior } \\ & \text { to December } 1992\end{aligned}$

Figure 12. Distribution of pH in ground water at the Penn Mine. A, April 1992. B, December 1992.

evaporated ground water with evaporated acid mine drainage from the retention pond.

\section{GEOCHEMICAL CORRELATIONS}

Correlations among dissolved constituents indicate the effects of acid mine drainage on ground-water quality at the Penn Mine. Dissolved iron and sulfate show a weak positive correlation in ground water, consistent with oxidation of pyrite as the probable source of these constituents (fig. 15). Other constituents show similar correlations, particularly with $\mathrm{pH}$. Lower $\mathrm{pH}$ values in ground water are associated with higher concentrations of dissolved constituents such as sulfate (fig. 11), aluminum, iron, and other dissolved metals.

The distribution of dissolved iron species is controlled by the $\mathrm{pH}$ and $\mathrm{Eh}$ of the ground water. The 


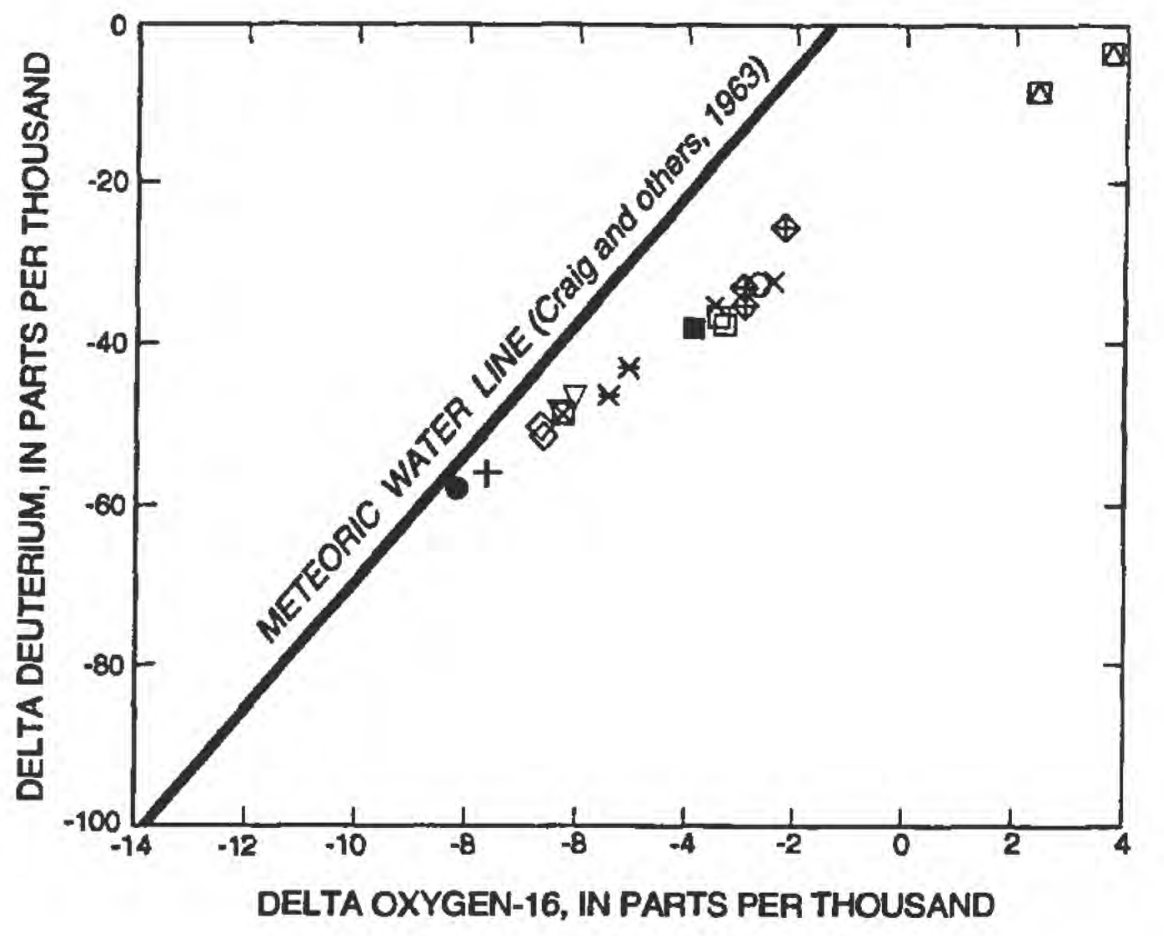

\begin{tabular}{|c|c|c|c|}
\hline & \multicolumn{3}{|c|}{$\begin{array}{l}\text { EXPLANATION } \\
\text { Ground Water }\end{array}$} \\
\hline$\square$ & GS-1A & $*$ & GS-5 \\
\hline+ & GS-2 & $\oplus$ & GS-6 \\
\hline$x$ & GS-3 & - & GS-7 \\
\hline 0 & GS-4A & 0 & GS-8A \\
\hline$\nabla$ & GS-4B & 回 & GS-8B \\
\hline$\otimes$ & \multicolumn{3}{|l|}{ GS $-4 C$} \\
\hline$\oplus$ & \multicolumn{3}{|c|}{$\begin{array}{l}\text { Mine Run Reservoir } \\
\text { R-1 foot below water s }\end{array}$} \\
\hline$\Delta$ & MRR-6 f & & surface \\
\hline
\end{tabular}

Figure 13. Stable-lsotopic composition of ground water and Mine Run Reservoir at the Penn Mine, April and December 1992.

Eh of an aqueous solution is a measure of the intensity of oxidizing or reducing (redox) conditions within a system with the hydrogen-electrode potential serving as a reference point of zero volts. A platinum electrode was used in the flow chamber during water sampling to measure the field potential of the ground water in volts. This determination was later converted to Eh. The $\mathrm{pH}$-Eh relations of aqueous solutions can predict and define the equilibrium behavior of multivalent elements. Positive potentials indicate that the system is relatively oxidizing, and negative potentials indicate that the system is relatively reducing. Redox potentials calculated from $E h$ values determined for ground water at the Penn Mine were all positive, ranging from $263 \mathrm{mV}$ (millivolts) at well GS-1B to $565 \mathrm{mV}$ at well GS-7. Values for redox potential are included in table 3.

Analytical determinations of dissolved ions presented in this report are for total concentrations and do not describe the aqueous species present. For example, a determination of total dissolved iron would not define the amounts of ferrous and ferric

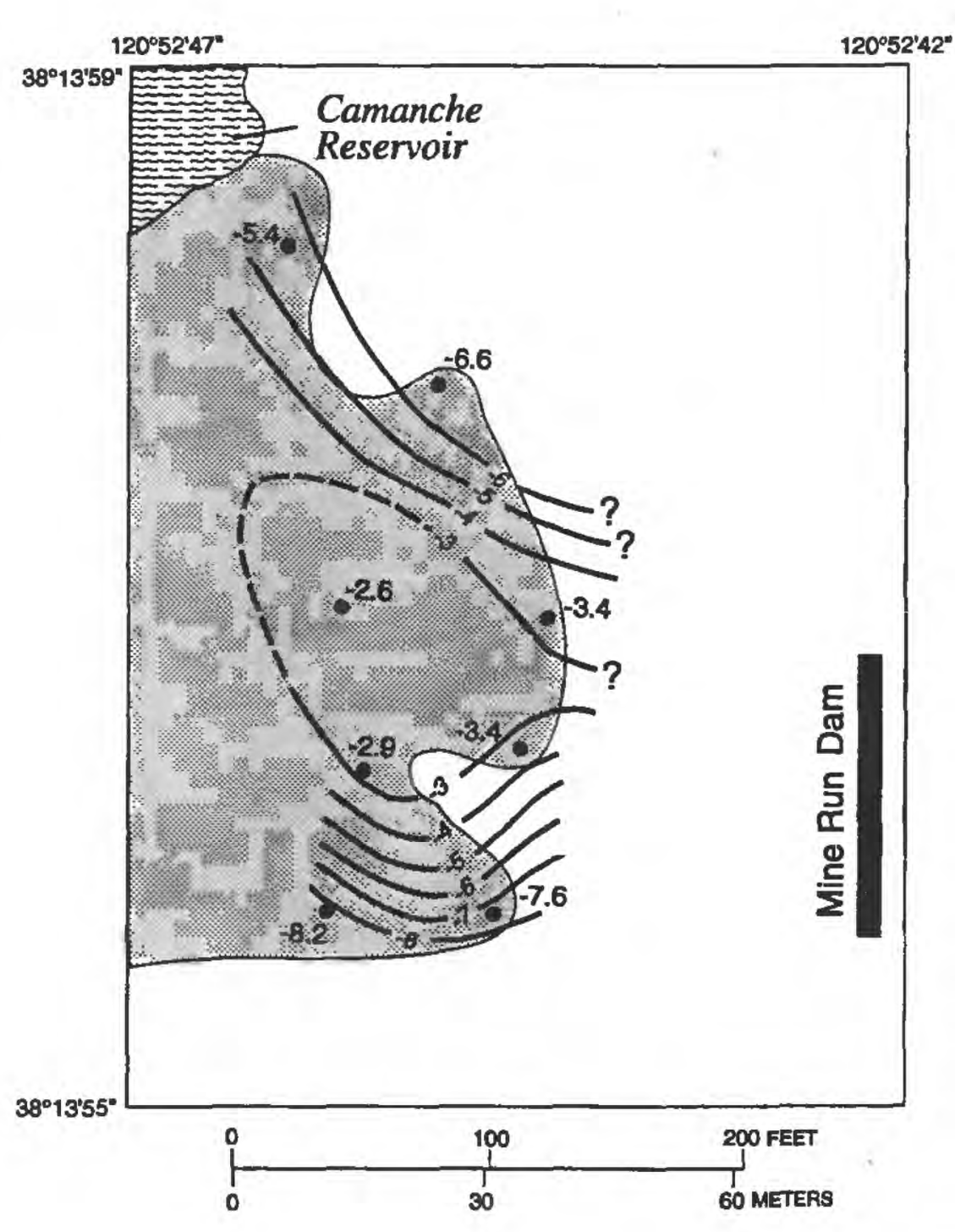

\section{EXPLANATION}

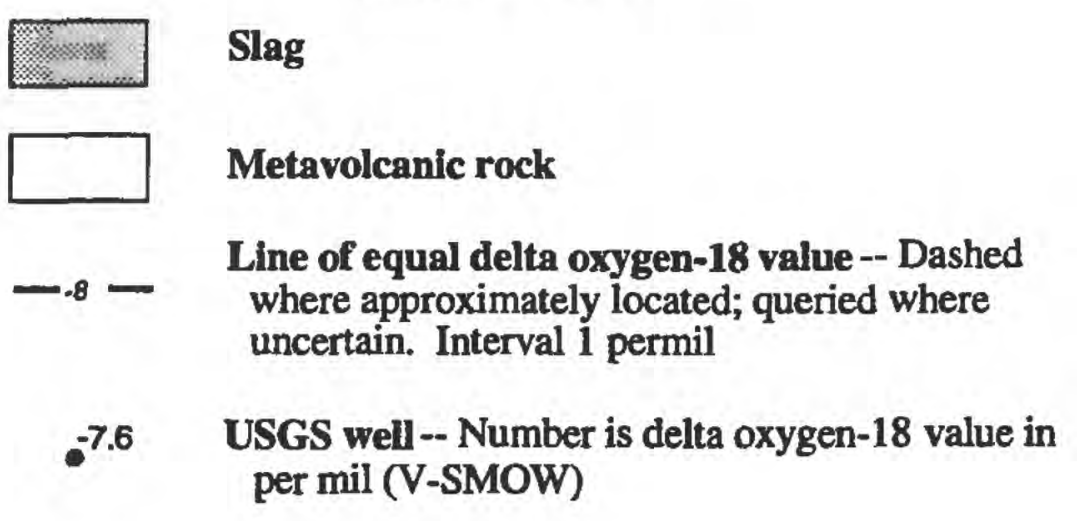

Figure 14. Distribution of delta oxygen-18 in ground water at the Penn Mine, April 1992.

iron in solution. Total and ferrous iron in solution can be determined analytically; the difference between the two is dissolved ferric iron. Iron species also may be determined theoretically from total iron concentrations using the $\mathrm{Eh}$ and $\mathrm{pH}$ of the solution. In this study, the chemical model WATEQ4F (Ball and Nordstrom, 1991) was used to determine dissolved species and their activities based on known thermodynamic data. The activity of a chemical 


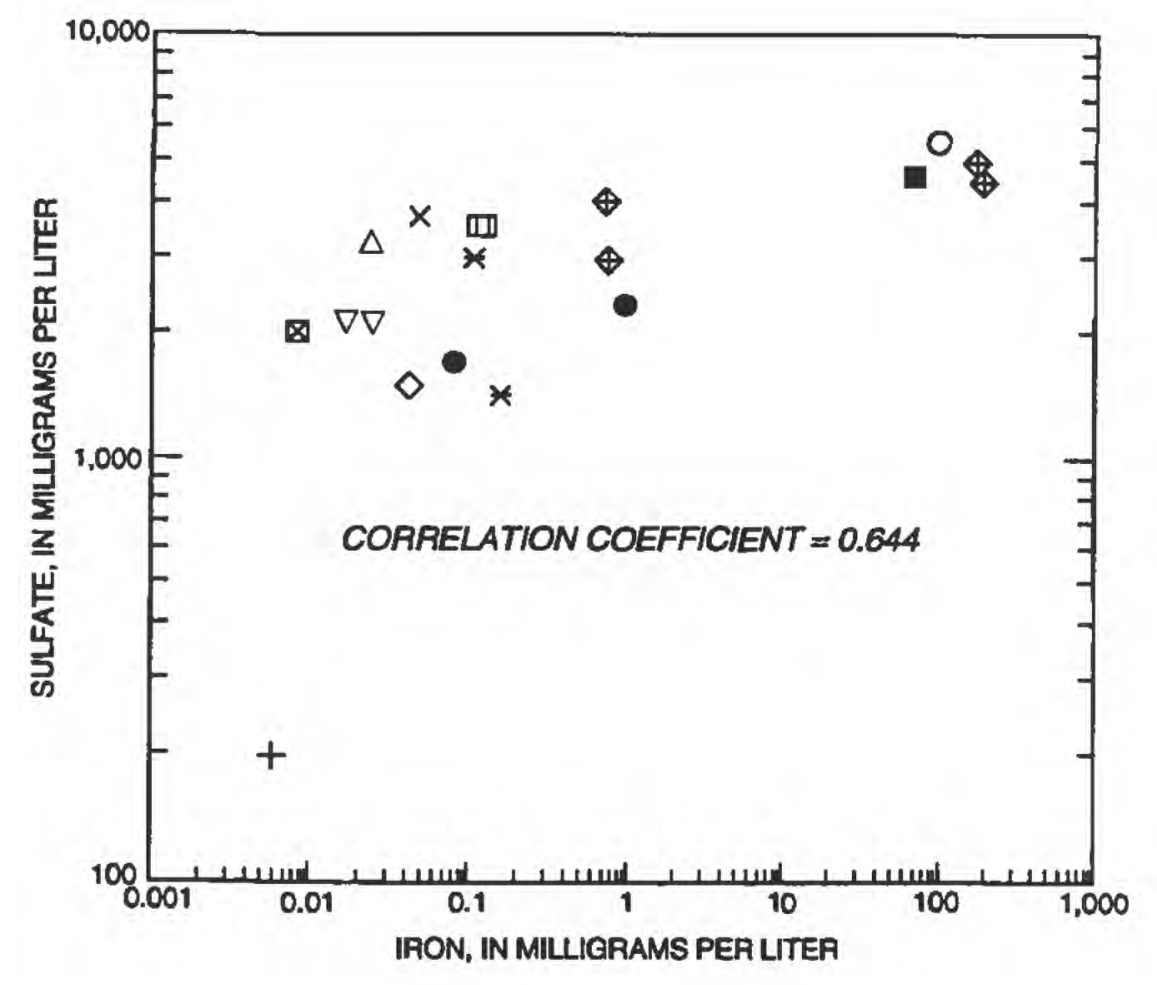

\begin{tabular}{lll}
\multicolumn{3}{c}{ EXPLANATION } \\
$\square$ GS-1A & $\otimes$ GS-4C \\
$\triangle$ & GS-1B & $*$ GS-5 \\
+ GS-2 & $\oplus$ GS-6 \\
$\times$ GS-3 & $\bullet$ GS-7 \\
$\diamond$ GS-4A & 0 GS-8A \\
$\nabla$ GS-4B & $\square$ GS-8B
\end{tabular}

Figure 15. Variation of iron with sulfate concentations in ground water from the Penn Mine, April 1992.

species is related to its analytical concentration by an aqueous activity coefficient, gamma $(\gamma)$

$$
a=\gamma m,
$$

where $a$ is the chemical activity and $m$ is the analytical concentration in molality (moles $/ \mathrm{kg} \mathrm{H}_{2} \mathrm{O}$ ). Aqueous activity coefficients are primarily dependent on the effective ionic strength of the aqueous solution; as total concentrations of species decreases, activity coefficients tend to approach unity. Because aqueous activities commonly are small numbers and range over several orders of magnitude, they generally are expressed as log values.

The concentrations of certain metals in natural waters may be controlled by solubility equilibrium with solid phases. If the controlling reaction contains the hydrogen ion, then a plot of $\mathrm{pH}$ against aqueous activity of the metal should yield a straight line with a slope corresponding to the stoichiometry of the controlling solubility reaction. The $\log$ of $\mathrm{Fe}^{3+}$ activity is plotted in figure 16 against $\mathrm{pH}$ in relation to solubility curves calculated for hydrous ferric oxide

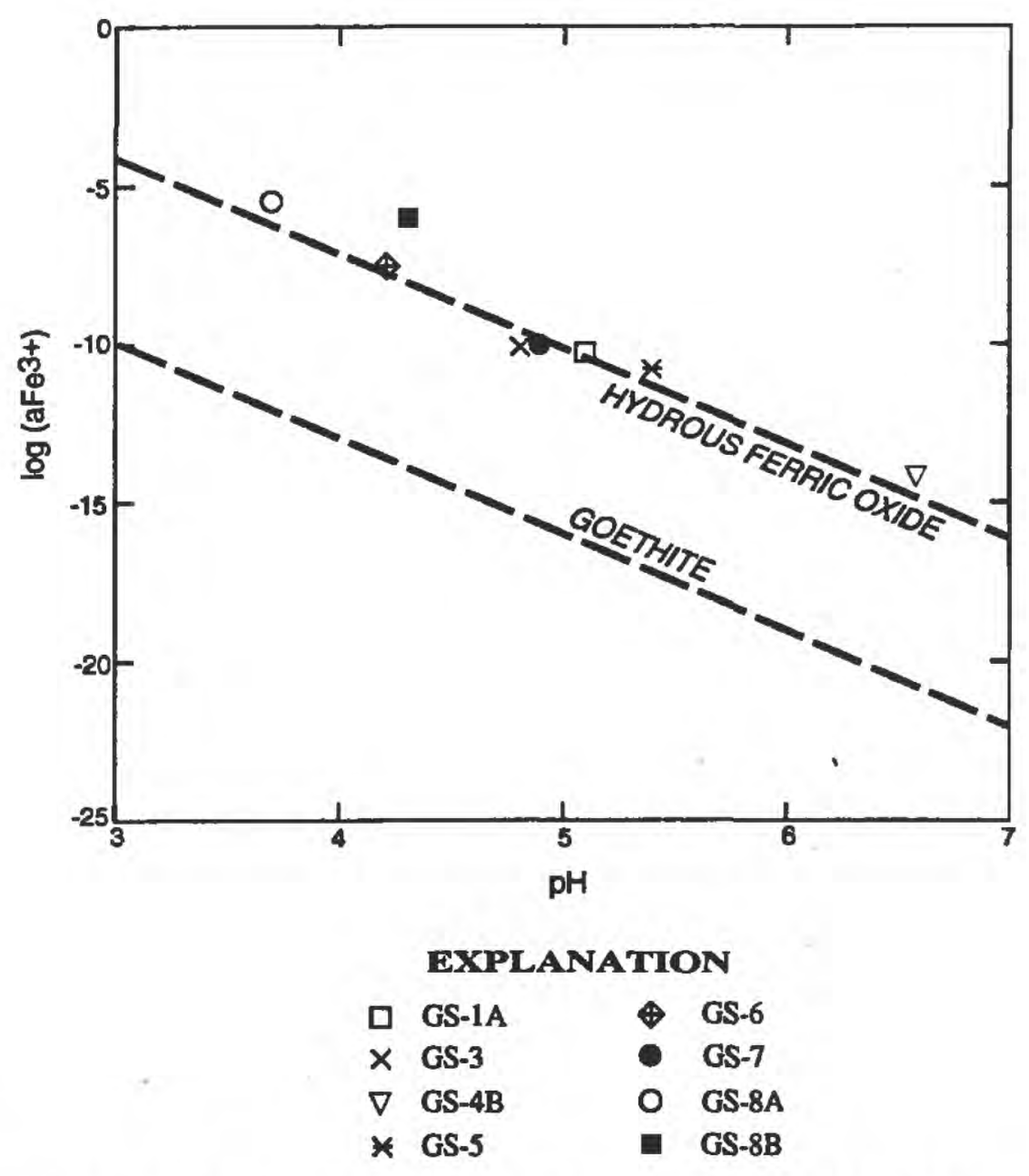

Figure 16. Plot of $\log \left(\mathrm{Fe}^{3+}\right.$ activity) and $\mathrm{pH}$ with goethite and hydrous ferric oxide equilibrium values for ground water from the Penn Mine, April 1992.

$\left.\mathrm{Fe}(\mathrm{OH})_{3}\right]$ and goethite $[\mathrm{FeO}(\mathrm{OH})]$ using thermodynamic data in WATEQ4F. With the exception of the lowest $\mathrm{pH}$ ground water from wells GS-8A and $-8 \mathrm{~B}$, the water appears to be close to equilibrium with hydrous ferric oxide. Sulfate concentrations become higher at low $\mathrm{pH}$ (fig. 11). The deviation of data points in figure 16 from the hydrous ferric oxide curve at low $\mathrm{pH}$ can reflect control by an iron-sulfate mineral such as jarosite $\left[\left(\mathrm{K}, \mathrm{Na}, \mathrm{H}_{3} \mathrm{O}\right) \mathrm{Fe}_{3}\left(\mathrm{SO}_{4}\right)_{2}(\mathrm{OH})_{6}\right]$ (Alpers and others, 1989) or a ferric-hydroxy-sulfate mineral such as the newly discovered, poorly crystalline schwertmannite $\left[\mathrm{Fe}_{8} \mathrm{O}_{8}(\mathrm{OH})_{6} \mathrm{SO}_{4}\right]$ (Bigham and others, 1990; Murad and others, 1994), for which no thermodynamic data are yet available.

A similar graphical analysis was applied to analytical data for dissolved aluminum in ground water at the Penn Mine. The $\log$ of $\mathrm{Al}^{3+}$ activity is plotted in figure 17 against $\mathrm{pH}$ in relation to solubility curves for amorphous and microcrystalline gibbsite. Ground water is in apparent equilibrium with crystalline gibbsite, with the exception of low $\mathrm{pH}$ water from wells GS-6, $-8 \mathrm{~A}$, and $-8 \mathrm{~B}$. Equilibrium with an aluminum-sulfate mineral can control the concentration of $\mathrm{Al}^{3+}$ species in the low $\mathrm{pH}$ range, or there 


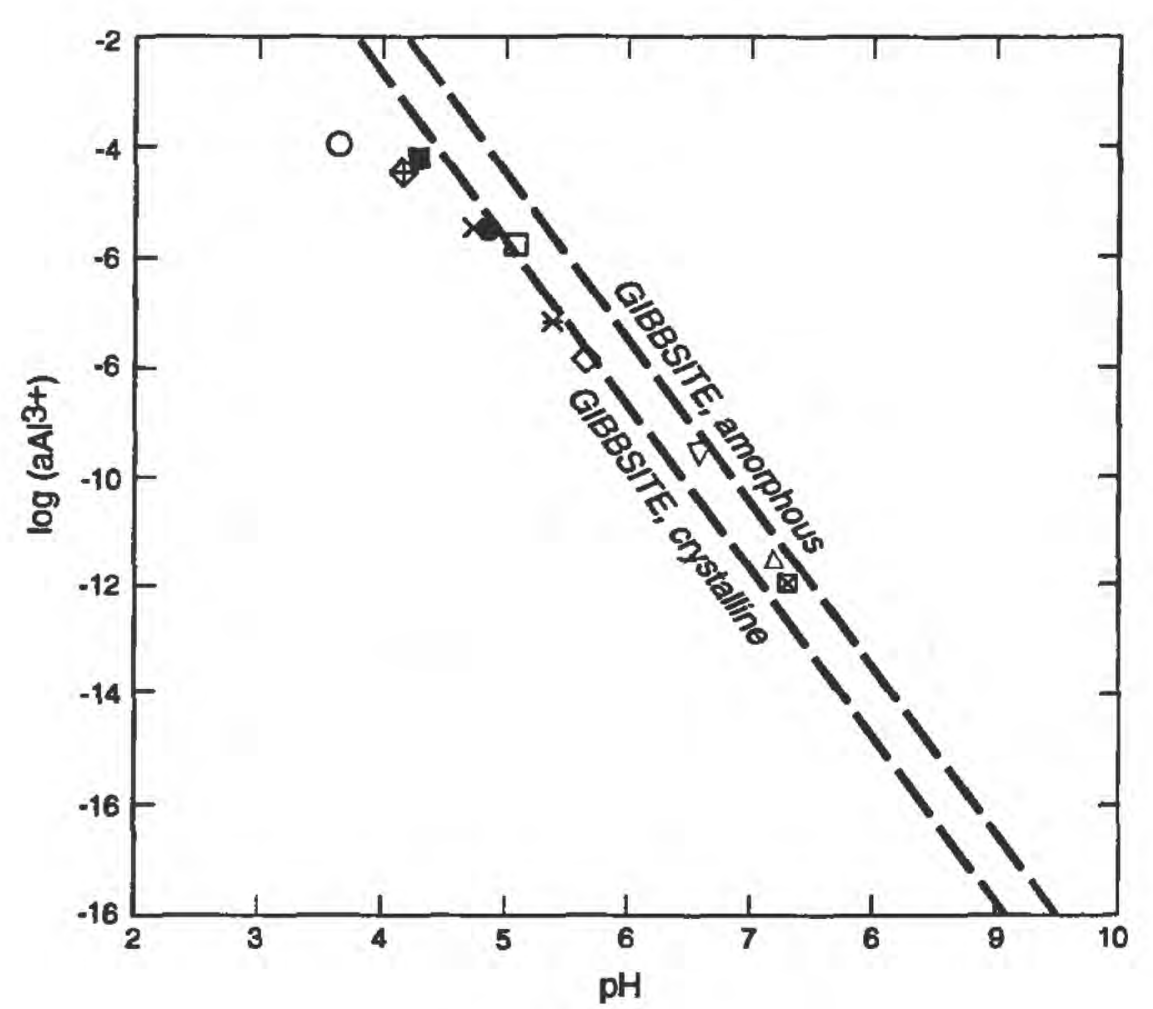

\begin{tabular}{|c|c|c|c|}
\hline & \multicolumn{3}{|c|}{ EXPLANATION } \\
\hline$\beth$ & GS-1A & $*$ & GS-5 \\
\hline$\Delta$ & GS-1B & 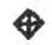 & GS-6 \\
\hline$x$ & GS-3 & - & GS-7 \\
\hline 0 & GS-4A & 0 & GS-8A \\
\hline 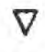 & GS $-4 B$ & (1) & GS-8B \\
\hline & GS $-4 \mathrm{C}$ & & \\
\hline
\end{tabular}

Figure 17. Plot of $\log \left(\mathrm{Al}^{3+}\right.$ activity) and $\mathrm{pH}$ with gibbsite equilibrium values for ground water from Penn Mine, April 1992.

may be no solubility control. Nordstrom and Ball (1986) observed that basic aluminum-sulfate minerals can control aluminum concentrations in waters having low $\mathrm{pH}$ and high sulfate concentrations. They noted that two possible controls on the aluminum chemistry of acid mine drainage were (1) the leaching rate of aluminum from common aluminosilicate minerals in sulfuric acid solutions and (2) the solubility of basic aluminum sulfate minerals known to exist under these conditions. Compared to surface water, ground water is in contact with mineral phases for much longer periods; consequently, ground water is exposed to much larger surface areas of minerals per unit time. Hence, ground water is expected to exhibit an increasing tendency toward mineral saturation and equilibrium with basic aluminum sulfate phases such as jurbanite $\left[\mathrm{Al}\left(\mathrm{SO}_{4}\right)(\mathrm{OH}) \cdot 5 \mathrm{H}_{2} \mathrm{O}\right]$ basaluminite $\left[\mathrm{Al}_{4}\left(\mathrm{SO}_{4}\right)(\mathrm{OH})_{10} \cdot 5 \mathrm{H}_{2} \mathrm{O}\right]$, and alunite $\left[\mathrm{KAl}_{3}\left(\mathrm{SO}_{4}\right)_{2}(\mathrm{OH})_{6}\right]$ at low $\mathrm{pH}$ (Nordstrom, 1982). Kinetic barriers to alunite formation may lead to supersaturation of aqueous solutions with respect to this mineral under certain conditions.

\section{FLOW RATE OF CONTAMINATED GROUND WATER}

The flow rate of ground water in the fractured metamorphic-rock aquifer between Mine Run Dam and Camanche Reservoir can be estimated by using mathematical relations developed for porous media. According to Darcy's law, the flow rate, $q$, through a given cross-sectional area of aquifer is

$$
q=K I A,
$$

where $K$ is the hydraulic conductivity averaged over the thickness of the aquifer, $I$ is the hydraulic gradient, and $A$ is the cross-sectional area (Driscoll, 1987). Wells GS-1 and -8 lie roughly along the axis of the contaminated plume (fig. 3) and parallel to the direction of maximum hydraulic gradient, which was about 0.14 in August 1992. A rough estimate of the width of the plume is about $300 \mathrm{ft}$ based on contours of sulfate concentration (fig. 10). The primary fractures that transport ground water are in a 10-foot-thick zone associated with the metavolcanic-slate contact. This yields a cross-sectional area for the flow path of approximately $3,000 \mathrm{ft}^{2}$. The median value of hydraulic conductivity for the metavolcanic rock is about $0.1 \mathrm{ft} / \mathrm{d}$ (table 1). Therefore, $q=(0.1 \mathrm{ft} / \mathrm{d}$ ) $\left(3,000 \mathrm{ft}^{2}\right)(0.14)=42 \mathrm{ft}^{3} / \mathrm{d}$. This is equivalent to about $115,000 \mathrm{gal} / \mathrm{yr}$. Using a high value for $K, 50$ $\mathrm{ft} / \mathrm{d}$, yields a discharge of about $21,000 \mathrm{ft}^{3} / \mathrm{d}$, or about $57 \mathrm{million} \mathrm{gal} / \mathrm{yr}$. The actual value for $q$ is proportional to the width of the plume and to the effective hydraulic conductivity along the flow path. Seasonal changes in the hydraulic gradient also will affect the ground-water discharge rate.

\section{METAL LOADING TO CAMANCHE RESERVOIR}

Using the estimates of ground-water flow along a path leading to Camanche Reservoir described in the previous section, ranges for metal transport rates can be estimated using values for metal concentration determined for the containment plume. Metal concentrations chosen for these estimates are $85 \mathrm{mg} / \mathrm{L}$ for copper, based on an average of the JanuaryFebruary and April 1992 samples from well GS-8A; $300 \mathrm{mg} / \mathrm{L}$ for zinc, based on values from wells GS$8 \mathrm{~A}$ and $-8 \mathrm{~B}$; and $1.5 \mathrm{mg} / \mathrm{L}$ for cadmium, based on an average of values for January-February and April 1992 samples from well GS-8A (table 3). 
Table 4. Estimates of ground-water flow and metal loading to Camanche Reservoir

[Assumed concentrations in plume are 1.5 milligrams per liter for cadmium, 85 milligrams per liter for copper, and 300 milligrams per liter for zinc. $\mathrm{ft} / \mathrm{d}$, foot per day; $\mathrm{ft}^{3} / \mathrm{d}$, cubic foot per day; gal/yr, gallon per year; $1 \mathrm{~b} / \mathrm{yr}$, pound per year]

\begin{tabular}{cccccr}
\hline $\begin{array}{c}\text { Hydraulic } \\
\text { conductivity } \\
(\mathrm{ft} / \mathrm{d})\end{array}$ & $\begin{array}{c}\text { Flow } \\
\text { rate } \\
(\mathrm{gal} / \mathrm{yr})\end{array}$ & $\begin{array}{c}\text { Flow } \\
\text { rate } \\
\left(\mathrm{ft}^{3} / \mathrm{d}\right)\end{array}$ & $\begin{array}{c}\text { Cadmium } \\
(\mathrm{lb} / \mathrm{yr})\end{array}$ & $\begin{array}{c}\text { Copper } \\
(\mathrm{lb} / \mathrm{yr})\end{array}$ & $\begin{array}{c}\text { Zinc } \\
(\mathrm{lb} / \mathrm{yr})\end{array}$ \\
\hline${ }^{1} 0.1$ & $1.15 \times 10^{5}$ & 42 & 1.5 & 86 & 310 \\
${ }^{2} 50$ & $5.7 \times 10^{7}$ & 21,000 & 750 & 42,000 & 150,000 \\
\hline
\end{tabular}

\footnotetext{
${ }^{1}$ Median value of hydraulic conductivity, metavolcanic rock.

${ }^{2}$ High value of hydraulic conductivity, metavolcanic rock.
}

The calculated metal loadings are shown in table 4 for median $(0.1 \mathrm{ft} / \mathrm{d})$ and high $(50 \mathrm{ft} / \mathrm{d})$ values of hydraulic conductivity. Because maximum values for metal concentrations in the contaminant plume were used, the metal loading estimates for the high value of hydraulic conductivity [copper, $42,000 \mathrm{lb} / \mathrm{yr}$ (pounds per year); zinc, 150,000 lb/yr; cadmium, $750 \mathrm{lb} / \mathrm{yr}$ ] can be considered "worst-case" scenarios. More realistic metal loading estimates can be obtained by consideration of the transient nature of the hydrologic system. In particular, the fluctuations of altitude of the surface of Camanche Reservoir appear to have an important effect on the direction of the hydraulic gradient, in the area of wells $-4 A,-4 B,-5,-8 A$, and $-8 \mathrm{~B}$. More detailed data are needed on water levels in these wells during and following fluctuations in Camanche Reservoir surface altitude to evaluate metal fluxes to Camanche Reservoir under transient ground-water conditions.

\section{SUMMARY}

The Penn Mine was active from the early 1860 's to the late 1950's. Metals produced from the mine in decreasing order of abundance were copper, zinc, silver, lead, and goild. Surface disposal of sulfidebearing waste rock and tailings has led to formation of acid mine drainage with high concentrations of dissolved aluminum, cadmium, copper, iron, zinc, and sulfate. Historically, contaminated surface runoff from the mine flowed directly into the Mokelumne River. Since the construction of Camanche Dam in 1963 , contaminated runoff has flowed into Camanche Reservoir. In an attempt to reduce the interaction of mine waste with surface water, diversion channels and unlined impoundments were constructed and existing impoundments were altered in 1979 to capture the runoff. The dams and dikes were constructed from available sulfide-bearing waste rock and tailings, except for Mine Run Dam, which has a clay core. Recirculation of water in the impoundments has led to evaporative concentration; leaching from containment materials is likely to release additional metal to the ponds. However, there has been no clear increase in metal concentrations in the ponds from 1987 to 1991 (Davy Environmental, 1993). This lack of increase suggests that significant quantities of metals are being removed either by precipitation as solids on the pond bottoms or by leakage to ground water. The results of this study suggest that contaminated ground water flows from the unlined impoundment behind Mine Run Dam, through an aquifer composed of fractured metamorphic rock along a flow path in the direction of Camanche Reservoir.

The principal bedrock units affecting the distribution of ground water are the metavolcanic Gopher Ridge Volcanics sequence and the metasedimentary Salt Spring slate. Massive sulfide ore bodies are associated with the metavolcanic complex. Ground water flows through fractures in the two rock types (metavolcanic rock and slate) and along the fault contact between these units. Flow appears to follow the strike of this contact, generally $\mathrm{N} 20^{\circ} \mathrm{W}$. The contact also may act as a barrier to downward flow from the metavolcanic rock to the underlying siate. A second fault hypothesized in the study area, striking approximately $\mathrm{N} 70^{\circ} \mathrm{E}$, also may affect ground-water flow in a manner similar to the lithologic contact. Median values of hydraulic conductivity estimated for the rock units range from 0.002 foot per day in the slate to 0.10 foot per day in the metavolcanic rock. Consequently, ground-water flow is primarily in the fractured metavolcanic unit. Static water levels generally are higher in the slate unit than in the metavolcanic unit, reflecting recharge at a higher elevation and providing another reason why the slate may act as a barrier to ground-water flow. Within the metavolcanic unit, water levels are highest near Mine Run Dam and lowest near Camanche Reservoir. Therefore, ground-water flows from the unlined impoundment behind Mine Run Dam toward Camanche Reservoir.

Results of analyses of samples collected from eight wells on three occasions in 1992 were used to evaluate the chemical character of ground water between Mine Run Dam and Camanche Reservoir. Specific conductance of the water ranged from 1,430 microsiemens per centimeter at well GS-2 to 18,000 microsiemens per centimeter at well GS-6. The pH 
of sampled water ranged from 3.7 at well GS-8A to 7.8 at well GS-2. Comparison of field water-quality data for April and December 1992 indicates a drop in $\mathrm{pH}$ at several of the sampling points, most notably at well GS-5, in which $\mathrm{pH}$ decreased from 5.4 to 4.6 in this period. This trend suggests that the contaminant plume containing the products of sulfide oxidation and pond evaporation was moving toward Camanche Reservoir at an observable rate.

The oxidative dissolution of pyrite is a major source of the acid mine drainage, characterized by low $\mathrm{pH}$ and high concentrations of sulfate and metals. At the Penn Mine, dissolved copper in ground water samples ranged from less than 0.010 to 88 milligrams per liter. Dissolved iron and aluminum ranged from less than 0.010 to 240 and 250 milligrams per liter, respectively. Dissolved zinc and cadmium ranged from 0.020 to 470 milligrams per liter and $<0.010$ to 3.7 milligrams per liter, respectively. The distribution of these and other constituents define the extent of a plume of acid mine drainage in the fractured groundwater aquifer downgradient from Mine Run Dam. Other dissolved constituents (calcium, magnesium, and potassium) show a similar distribution to the trace metals in ground water, with the exception of sodium and chloride, which are associated with a source in the slate unit.

A plume of contaminated water in the metavolcanic unit is delineated by $\mathrm{pH}$, stable isotopes of oxygen and hydrogen, dissolved sulfate, and dissolved metals. The source of the plume seems to be in or near the metavolcanic unit along the north abutment of Mine Run Dam. The lowest values for $\mathrm{pH}$ are associated with the highest concentrations of sulfate and dissolved metals in ground water. The areas of lowest $\mathrm{pH}$ correspond to the axis of the plume and are associated with isotopic compositions enriched in heavy isotopes $\left(\delta \mathrm{D}\right.$ and $\left.\delta^{18} \mathrm{O}\right)$. The isotopic enrichment most likely results from evaporation of the pond water and subsequent filtration into the ground-water system. Most ground-water flow is in a west-to-northwesterly direction from Mine Run impoundment toward Camanche Reservoir. Groundwater discharge at lowflow conditions is estimated to be (for example, using hydraulic gradients from August 1992) from 42 to 21,000 cubic feet per day $\left(10^{5}\right.$ to $5 \times 10^{7}$ gallons per year), based on an equivalent-porous-medium approximation.

Corresponding fluxes of dissolved metals to Camanche Reservoir from the contaminated groundwater plume below Mine Run Dam are estimated to fall within the following ranges: for copper, 86 to
42,000 pounds per year; for zinc, 310 to 150,000 pounds per year; and for cadmium, 1.5 to 750 pounds per year. Additional ground-water monitoring and numerical modeling of ground-water flow and transport would help to refine these crude estimates and to quantify uncertainties.

\section{References}

Alpers, C.N., and Nordstrom, D.K., 1991, Geochemical evolution of extremely acid mine waters at Iron Mountain, California: Are there any lower limits to $\mathrm{pH}$ ? in Proceedings, Second International Conference on the Abatement . of acidic drainage, MEND (Mine Environment Neutral Drainage), Montréal, Québec, Canada, September 16-18, 1992, v. 2, p. 321-342.

Alpers, C.N., Nordstrom, D.K., and Ball, J.W., 1989, Solubility of jarosite solid solutions precipitated from acid mine waters, Iron Mountain, California, U.S.A.: Sciences Géologiques, Bullettn, v. 42, p. 281-298.

Ball, J.W., and Nordstrom, D.K., 1991, User's manual for WATEQ4F, with revised thermodynamic data and test cases for calculating speciation of major, trace, and redox elements in natural waters: U.S. Geological Survey Open-File Report 91-183, 189 p.

Bigham, J.M., Schwertmann, U., Carlson, L., and Murad, E., 1990. A poorly crystalline oxyhydroxy sulfate of iron formed by bacterial oxidation of $\mathrm{Fe}$ (II) in acid mine waters: Geochimica et Cosmochimica Acta, v. 54, p. 2743-2758.

Bond, S.R., 1988, Penn Mine Toxic Pits Cleanup Act technical investigation report: California Regional Water Quality Control Board, Central Valley Region, Sacramento, 36 p. (plus 3 appendixes).

Clark, L.D., 1964, Stratigraphy and structure of part of the western Sierra Nevada metamorphic belt, California: U.S. Geological Survey Professional Paper 410, 70 p.

Clark, W.B., and Lydon, P.A., 1962, Mines and mineral resources of Calaveras County, California: California Division of Mines and Geology, County Report 2.

Craig, H., Gordon, L.I., and Horibe, T., 1963, Isotope exchange effects in the evaporation of water: Journal of Geophysical Research, v. 68, p. 5079-5087.

Coplen, T.B., Wildman, J.D., and Chen, J., 1991, Improvements in the gaseous hydrogen-water equilibration technique for hydrogen isotope ratio analysis: Analytical Chemistry, v. 63, p. 910-912.

Davy Environmental, 1993, Site Characterization Report, Penn Mine, Calaveras County, California: Prepared for California Regional Water Quality Control Board, Central Valley Region, 174 p., plus 8 drawings and 2 appendices.

Driscoll, F.G., 1987, Groundwater and wells (2d ed): St. Paul, Minnesota, Johnson Division, 1089 p.

Dunham, R., 1961, Report on pollution at the Mokelumne River by the Penn Mine, Calaveras County, California: California Department of Fish and Game, Report to Central Valley Regional Water Pollution Control Board, 28 p. 
Epstein, S., and Mayeda, T., 1953, Variation of ${ }^{18} \mathrm{O}$ content of waters from natural sources: Geochimiceat Cosmochimica Acta, v. 4, p. 213-224.

Finlayson, B.J., and Rectenwald, H.J., 1978, Toxicity of copper and zinc from the Penn Mine area on king salmon (Oncorhynchus Tshawytscha) and steelhead trout (Salmo Gairdneri) in the Mokelumne River Basin, California: California Department of Fish and Game, Environmental Services Branch, Administrative Report 78-1, $42 \mathrm{p}$.

Fishman, M.J., and Friedman, L.C., 1985, Methods for determination of inorganic substances in water and fluvial sediments: U.S. Geological Survey Techniques of Water-Resources Investigations, Book 5, chap. A1, $709 \mathrm{p}$.

Gringarten, A.C., 1982, Flow-test evaluation of fractured reservoirs: Geological Society of America Special Paper 189 , p. 237-262.

Hem, J.D., 1977, Reactions of metal ions at surfaces of hydrous iron oxide: Geochimica et Cosmochimica Acta, v. 41, p. $527-538$.

Hem, J.D., 1985, Study and interpretation of the chemical characteristics of natural water: U.S. Geological Survey Water-Supply Paper 2254, 263 p.

Hess, A.E., 1986, Identifying hydraulically conductive fractures with a slow-velocity heat-pulse flowmeter: Canadian Geotechnical Journal, v. 23, no. 1, p. 69-78.

Heyl, G.R., Cox, M.W., and Eric, J.H., 1948, Penn zinc-copper mine, Calaveras County: California Division of Mines Bulletin 144, p. 61-84.

Huntley, D., Nommensen, R., and Steffey, D., 1992, The use of specific capacity data to assess transmissivity in fractured-rock aquifers: Ground Water, v. 30 , no. 3, p. 396-402.

Lee, R.R., Kettelle, R.H., Bownds, J.M., and Rizk, T.A., 1992, Aquifer analysis and modeling in a fractured, heterogeneous medium: Ground Water, v. 30, no. 4, p. 589-597.

Makita, S.N., and Fujii, Roger, 1992, Quality assurance practices of the U.S. Geological Survey laboratory in Sacramento, California: U.S. Geological Survey OpenFile Report 91-522, 23 p.

Martin, R.C., 1988, Volcanogenic massive sulfide belt of the western Sierra Nevada Mountains: Geology 41, p. 195-204.

McKibben, M.A., and Barnes, H.L., 1986, Oxidation of pyrite in low temperature acidic solutions: Rate laws and surface textures: Geochimica et Cosmochimica Acta, v. 50, p. 1509-1520.

Murad, E., Schwertmann, U., Bigham, J.M., and Carlson, L., 1994, Mineralogical characteristics of poorly crystalline precipitates formed by oxidation of $\mathrm{Fe}^{2+}$ in acid sulfate waters, in Alpers, C.N., and Blowes, D.W., eds., Environmental Geochemistry of Sulfide Oxidation, ACS Symposium Series, v. 550: American Chemical Society, Washington, D.C., p. 190-200.

Nordstrom, D.K., 1982, The effect of sulfate on aluminum concentrations in natural waters: Some stability relations in the system $\mathrm{Al}_{2} \mathrm{O}_{3}-\mathrm{SO}_{3}-\mathrm{H}_{2} \mathrm{O}$ at $298 \mathrm{~K}$ : Geochimica et Cosmochimica Acta, v. 46, p. 681-692.
Nordstrom, D.K., 1985, The rate of ferrous iron oxidation in a stream receiving acid mine effluent, in Selected Papers in the Hydrological Sciences: U.S. Geological Survey Water-Supply Paper 2270, p. 113-119.

Nordstrom, D.K., and Ball, J.W., 1986, The geochemical behavior of aluminum in acidified surface waters: Science, v. 232, p. 54-56.

O'Neill, J.R., 1986, Terminology and standards, in Valley, J.W., Taylor, J.P., Jr., and O'Neill, J.R., eds., Stable Isotopes in High Temperature Geologic Processes, Reviews in Minerology, v. 16, p. 561-570.

Paillet, F.L., Hess, A.E., Cheng, C.H., and Hardin, E.L., 1987, Characterization of fracture permeability with high-resolution vertical flow measurements during pumping: Ground Water, v. 25, no. 1, p. 28-40.

Paillet, F.L., and Kapucu, K., 1989, Fracture characterization and fracture-permeability estimates from geophysical logs in the Mirror Lake watershed, New Hampshire: U.S. Geological Survey Water-Resources Investigations Report 89-4058, 49 p.

Papadopoulos, I.S., and Cooper, H.H., 1967, Drawdown in a well of large diameter: Water Resources Research, v. 3 , no. 1 , p. 241-244.

Peterson, J.A., 1985, Geologic map of the Penn Mine, Calaveras County, California: U.S. Geological Survey Miscellaneous Field Studies Map MF-1797.

1988, Distribution of selected trace and major elements around the massive sulfide deposit at the Penn Mine, California: Economic Geology, v. 83, p. 419-427.

Schweickert, R.A., 1981, Tectonic evolution of the Sierra Nevada range, in Ernst, W.G., ed., The Geotectonic Evolution of California: Englewood Cliffs, New Jersey, Prentice-Hall, p. 87-131.

Shaw, P., and Towers, C.L., 1937, Water pollution problems in California: Fish and Game, California, v. 23 , no. 4 , p. $262-285$.

Singer, P.C., and Stumm, W., 1970, Acid mine drainage: the rate-determining step: Science, v. 167, p. 1121-1123.

Todd, D.K., 1980, Groundwater Hydrology: New York, John Wiley, 535 p.

Webster, J.G., Nordstrom D.V., and Smith K.S., 1994, Transport and natural attenuation of $\mathrm{Cu}, \mathrm{Zn}, \mathrm{As}$, and $\mathrm{Fe}$ in the acid mine drainage of Leviathan and Bryant Creeks, in Alpers C.N. and Blowes, D.W., eds., Environmental Geochemistry of Sulfide Oxidation, ACS Symposium Series, v. 550: American Chemical Society, Washington D.C., p. 244-260.

Wiebelt, F.J., and Ricker, S., 1948, Penn Mine slag dump and mine water, Calaveras County, Calif.: U.S. Bureau of Mines, Report of Investigations 4224, $6 \mathrm{p}$.

Wood, W.W., 1976, Guidelines for the collection and field analysis of ground-water samples for selected unstable constituents: U.S. Geological Survey Techniques of Water-Resources Investigations, Book 1, chap. D2, 24 p.

Zemanek, J., Glenn, E.E., Morton, L.J., and Caldwell, R.L., 1970, Formation evaluation by inspection with the borehole televiewer: Geophysics, v. 35, p. 254-269. 
APPENDIX 1. Geophysical logs from U.S. Geological Survey monitoring wells GS-1 through GS-8 at Penn Mine site.

\section{EXPLANATION OF TELEVIEWER LOGS}

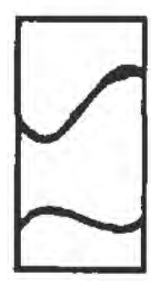

Isolated planes intersecting borehole; probably open fractures.

Fracture zone composed of several parallel and intersecting fractures.

Faint discontinuous planes intersecting borehole; probably foliation in greenschist.

Large opening intersecting borehole; shape of top of opening may indicate orientation.

Intensely fractured and altered rock; orientation of individual fractures difficult to determine.

Bottom of casing above open borehole.

Top of fluid column in open borehole.

Lowermost interval of borehole inaccessible to televiewer. 
APPENDIX 1. Geophysical logs from U.S. Geological Survey monitoring wells GS-1 through GS-8 at Penn Mine site-Continued

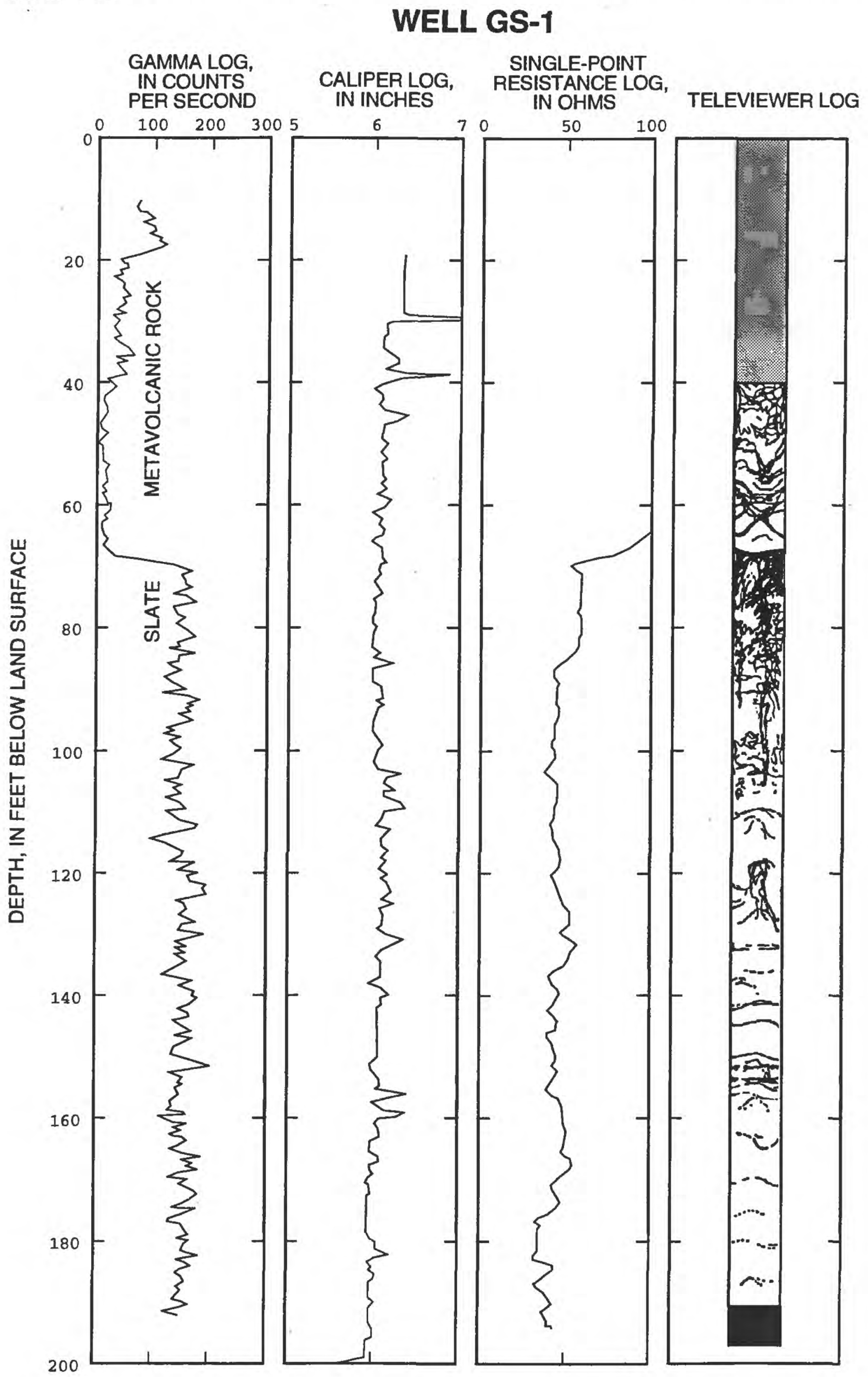


APPENDIX 1. Geophysical logs from U.S. Geological Survey monitoring wells GS-1 through GS-8 at Penn Mine site-Continued

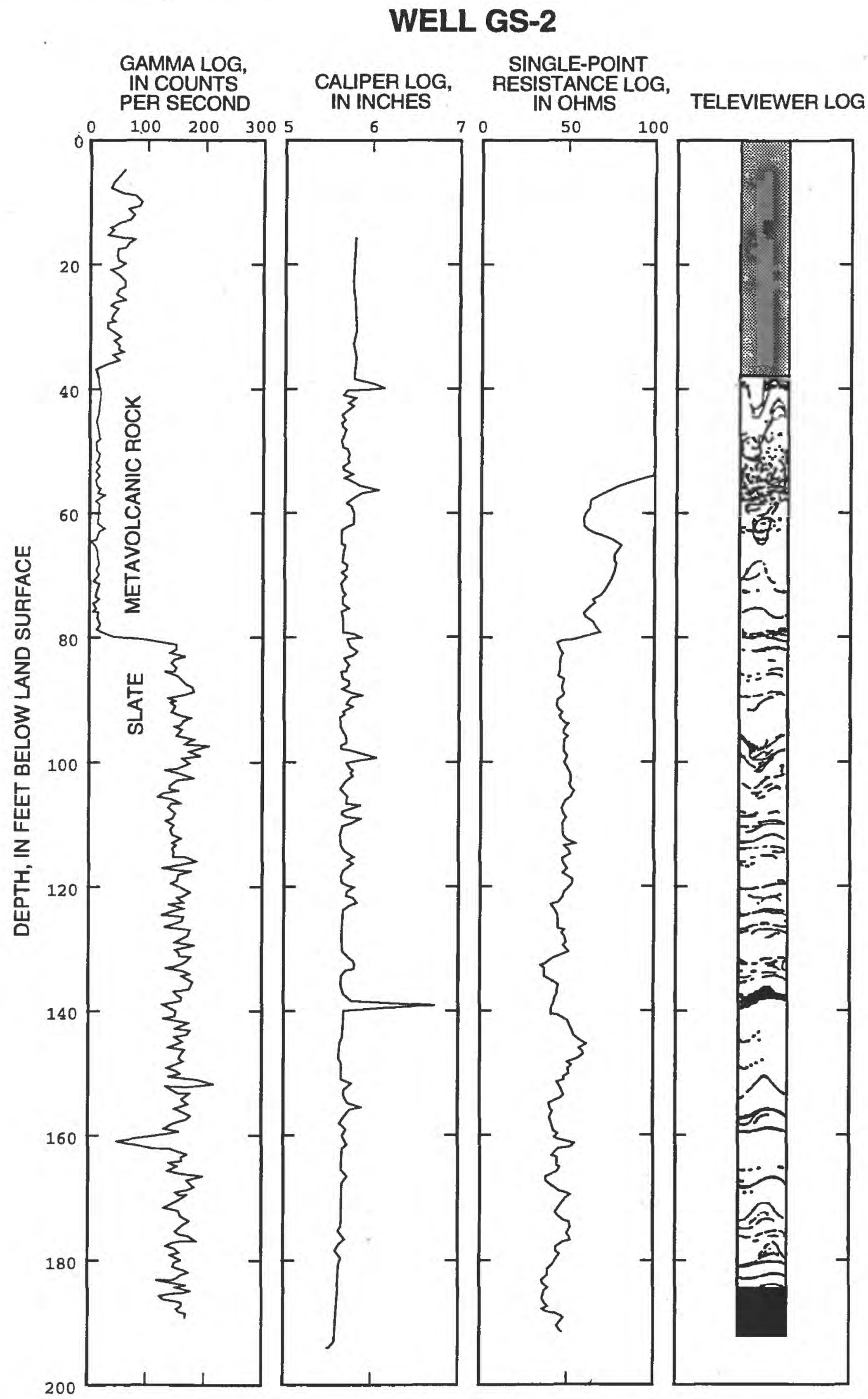


APPENDIX 1. Geophysical logs from U.S. Geological Survey monitoring wells GS-1 through GS-8 at Penn Mine site-Continued

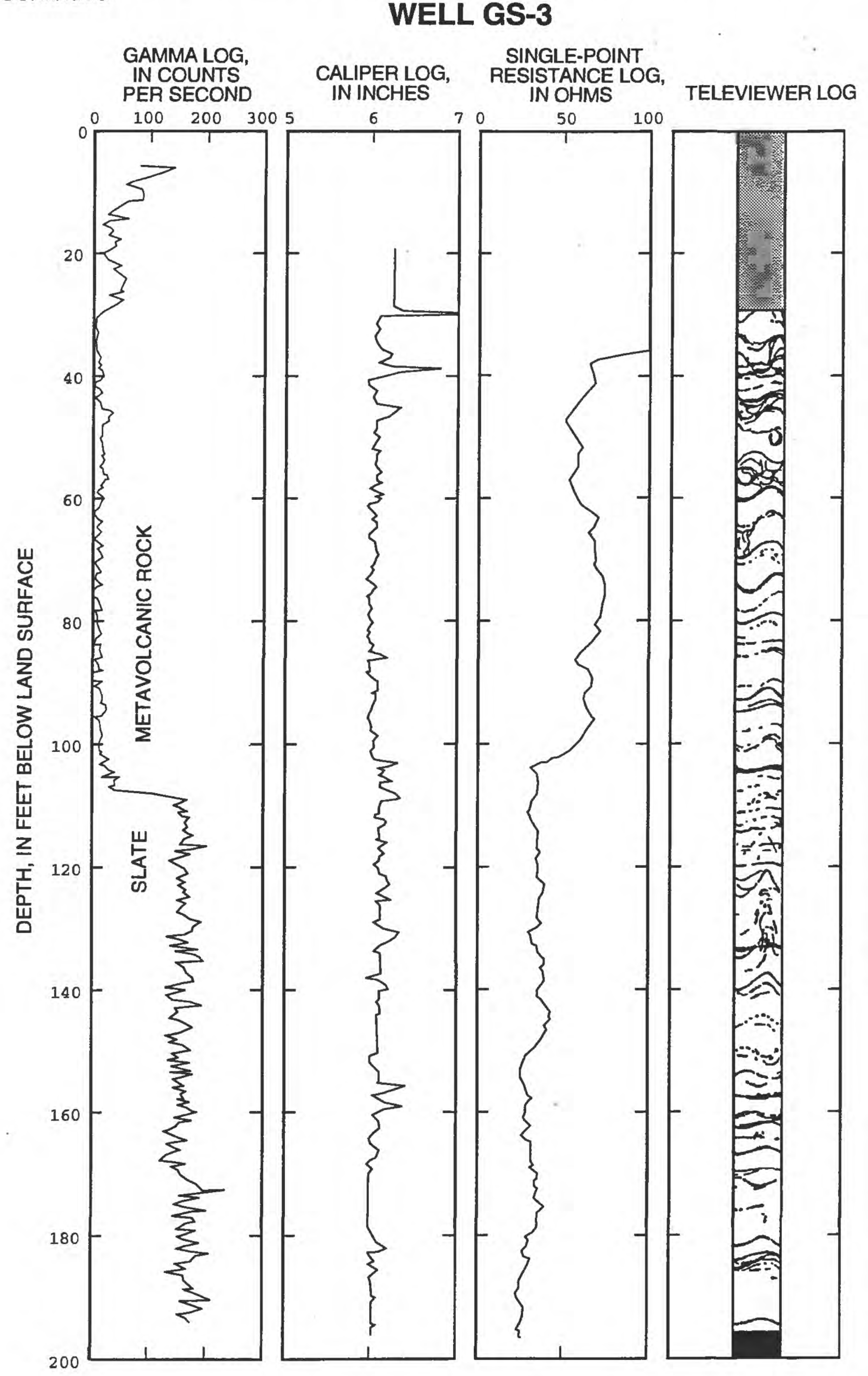


APPENDIX 1. Geophysical logs from U.S. Geological Survey monitoring wells GS-1 through GS-8 at Penn Mine site-Continued

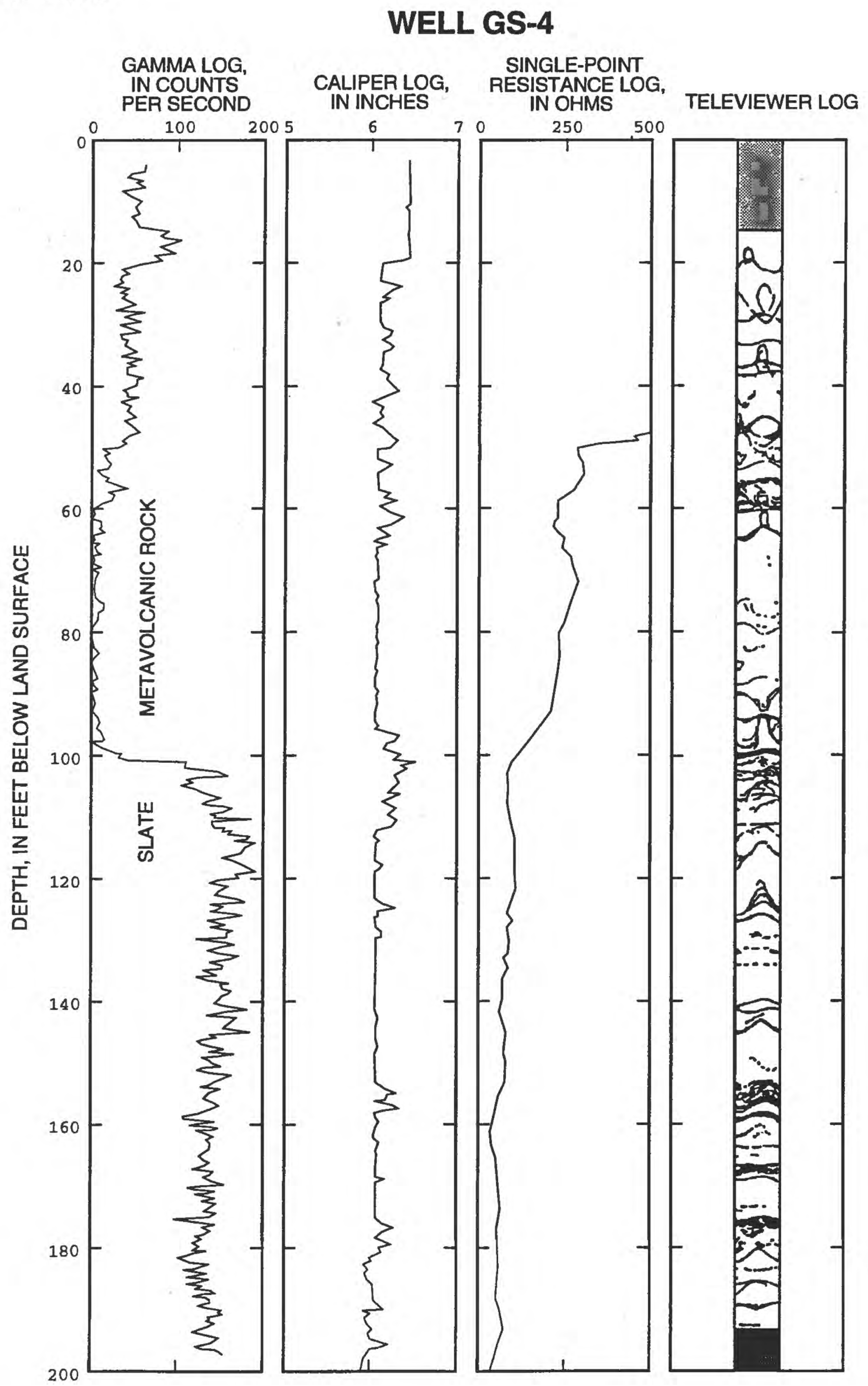


APPENDIX 1. Geophysical logs from U.S. Geological Survey monitoring wells GS-1 through GS-8 at Penn Mine site-Continued

\section{WELL GS-5}

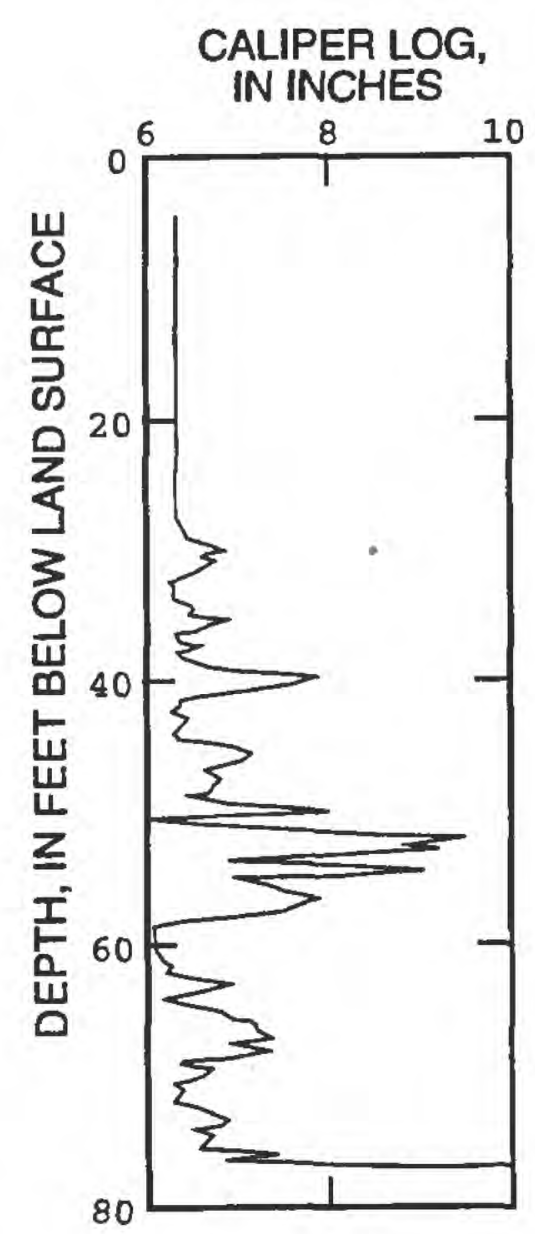


APPENDIX 1. Geophysical logs from U.S. Geological Survey monitoring wells GS-1 through GS-8 at Penn Mine site-Continued

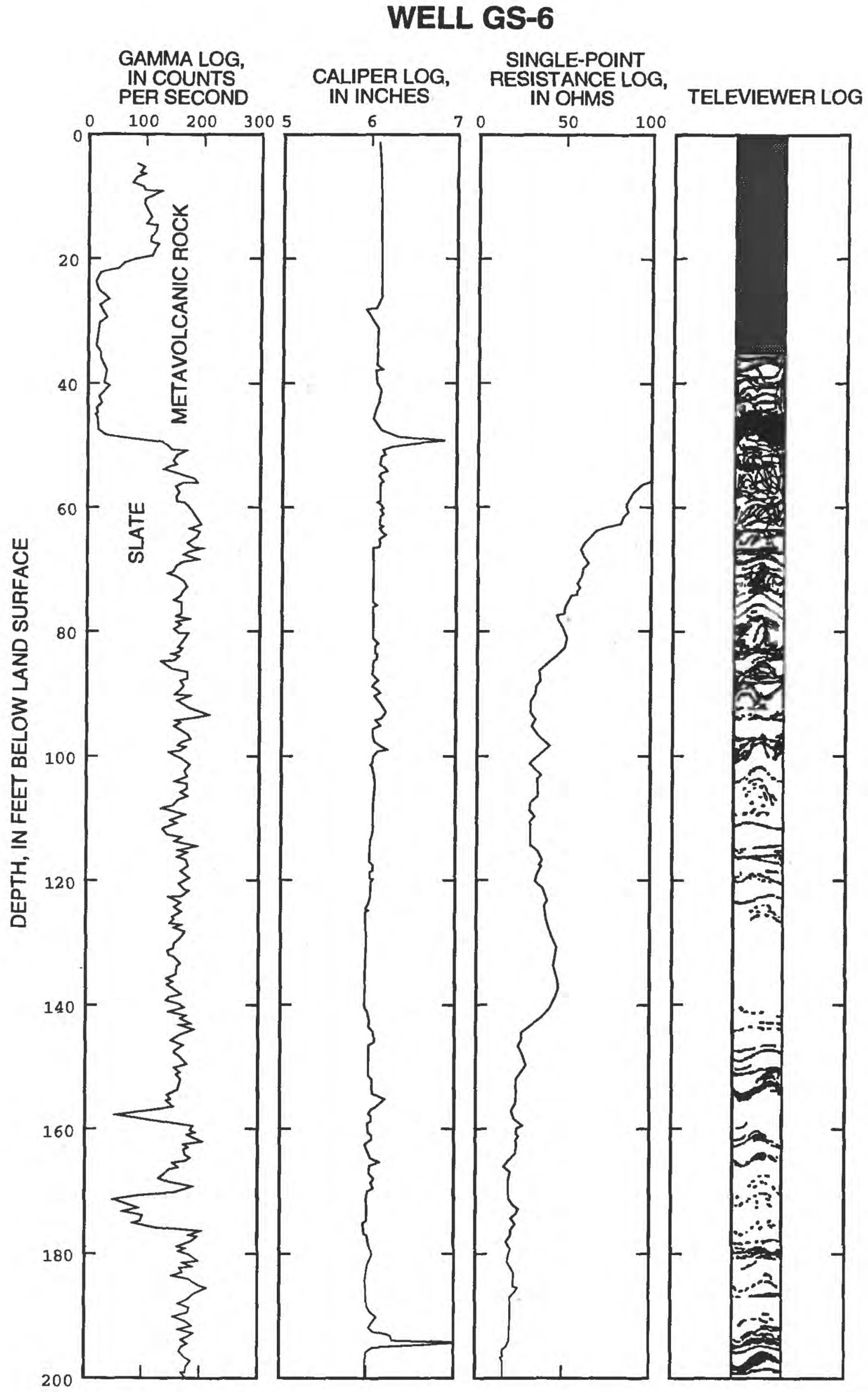


APPENDIX 1. Geophysical logs from U.S. Geological Survey monitoring wells GS-1 through GS-8 at Penn Mine site-Continued

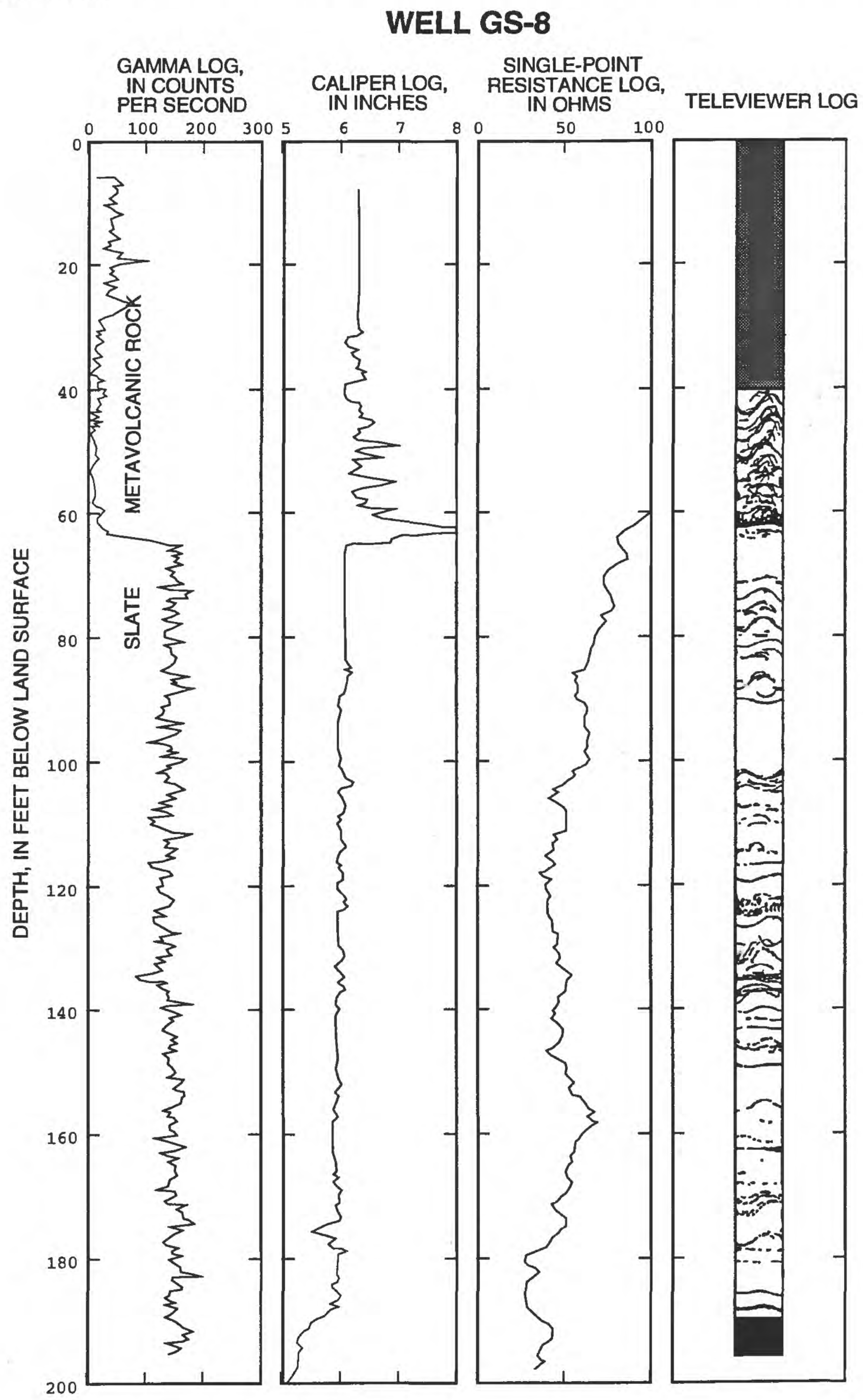


APPENDIX 2. Flowmeter data from U.S. Geological Survey monitoring wells GS-1 through GS-8 at Penn Mine site

[ft, foot, gal/min, gallon per minute; NF, no flow; >, value greater than value shown; <, value less than value shown; $\Delta t(s)$, time in seconds for next pulse to reach thermister; $1 / \Delta t$, inverse of $\Delta t\left(s^{-1}\right) ;+$, packer inflated; 0 , packer not inflated; ,-- no data]

Well

No.

Depth

Packer $^{1}$ Date/

Date/
Direction

$\Delta \mathrm{t}(\mathrm{s})$

$1 / \Delta t\left(s^{-1}\right)$

Flow

11-14-91

55

Static

--

$-$

11-14-91

GS-1

Injection

55

35

45

GS-2

94

GS-2

$\begin{array}{ll} & \text { Injection } \\ 36 & + \\ 45 & +\end{array}$

GS-3

80

145

GS-3

GS-4

GS-4

$\begin{array}{ll} & \text { Injection } \\ 15 & 0^{1} \\ 30 & 0 \\ 47 & 0 \\ 55 & 0 \\ 70 & 0 \\ 70 & +\end{array}$

GS-5

60

43

43

GS-5

GS-6

GS-6

GS-7

GS-7
Static

$+$

Injection

$+$

$+$

Static

Static

$\stackrel{+}{0^{1}}$

$+$

Injection

Static

Injection

Static

Injection
Down

--

11-15-91

--

11-15-91

Down

--

11-14-91

$--$

11-14-91

Down

Noisy-probably no flow

$-$

11-16-91

Down

Down

Down

Down

Up

$-$

11-16-91

Up

--

-- (too much debris in well)

-- (too much debris in well)

-- (no well)

-- (no well)
15.0

$<0.02$

$<.02$

$\mathrm{NF}^{2}$

$>60<.02 \quad$ NF

$\begin{array}{crc}>60 & <.02 & \text { NF } \\ 9.8 & .10 & 0.08 \\ >60 & <.02 & \text { NF }\end{array}$

$>60 \quad<.02 \quad$ NF

$\begin{array}{lrl}3.2 & .31 & \text { NF }^{.28}\end{array}$

$>60 \quad<.02 \quad$ NF

$>60 \quad<.02 \quad$ NF

$--$

.07

.05

$--$

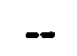

\section{5}

6.0

9.0

11.0

$15.5^{1}$

$>60$

.15

.17

.11

.09

.06

$<.02$

40

$>60$

18

.02
$<.02$
.06

$\mathrm{NF}^{3}$

NF

.05 
APPENDIX 2. Flowmeter data from U.S. Geological Survey monitoring wells GS-1 through GS-8 at Penn Mine site-Continued

\begin{tabular}{|c|c|c|c|c|c|c|}
\hline $\begin{array}{l}\text { Well } \\
\text { No. }\end{array}$ & $\begin{array}{l}\text { Depth } \\
\text { (ft) }\end{array}$ & Packer $^{1}$ & $\begin{array}{c}\text { Date/ } \\
\text { Direction }\end{array}$ & $\Delta t(s)$ & $1 / \Delta t\left(s^{-1}\right)$ & $\begin{array}{c}\text { Flow } \\
(\mathrm{gal} / \mathrm{min})\end{array}$ \\
\hline \multirow[t]{9}{*}{ GS-8 } & & Static & $11-16-91$ & & & \\
\hline & 55 & $0^{1}$ & Down & 5.0 & 0.20 & 1.0 \\
\hline & 50 & 0 & Down & 6.9 & .14 & .85 \\
\hline & 45 & 0 & Down & 5.0 & .20 & 1.0 \\
\hline & 43 & 0 & Down & 4.3 & .24 & 1.1 \\
\hline & 60 & 0 & Down & 7.6 & .13 & .75 \\
\hline & 55 & 0 & Down & 3.9 & .26 & 1.15 \\
\hline & 50 & 0 & Down & 6.8 & .15 & .9 \\
\hline & 45 & 0 & Down & 4.0 & .25 & 1.15 \\
\hline \multirow[t]{7}{*}{ GS-8 } & & Injectior & & & & . \\
\hline & 55 & $0^{1}$ & Down & 3.0 & .33 & 1.60 \\
\hline & 60 & 0 & Down & 3.0 & .33 & 1.60 \\
\hline & 65 & 0 & Unsteady - no results & -- & -- & - \\
\hline & 67 & 0 & -- & $>60$ & $<.02$ & NF \\
\hline & 62 & 0 & Unsteady - no results & -- & -- & -- \\
\hline & 67 & + & -- & $>60$ & $<.02$ & NF \\
\hline
\end{tabular}

${ }^{1}$ Packer is an inflatable bladder that focuses the entire flow in the borehole through the flowmeter. Measurements without packer inflated can yield erroneous upflow by driving a convective cell.

${ }^{2} \mathrm{NF}=$ "No flow" to within $0.02 \mathrm{gal} / \mathrm{min}$ resolution (with packer) or $0.25 \mathrm{gal} / \mathrm{min}$ resolution (without packer).

${ }^{3}$ Slight upflow is probably driven by buoyancy of heat pulse - probably no flow. 
APPENDIX 3. Purging-log data for U.S. Geological Survey monltorling wells GS-1 through GS-8 at Penn Mine site

[Column 7 divided by column 8 equals column 9. gal, gallon; --, no data]

\begin{tabular}{|c|c|c|c|c|c|c|c|c|c|}
\hline $\begin{array}{l}\text { Well } \\
\text { No. }\end{array}$ & $\begin{array}{c}\text { Purge } \\
\text { date }\end{array}$ & $\begin{array}{l}\text { Sample } \\
\text { date }\end{array}$ & $\begin{array}{l}\text { Volume } \\
\text { well bore } \\
\text { (gal) }\end{array}$ & $\begin{array}{l}\text { Volume } \\
\text { above } \\
\text { packer } \\
\text { (gal) }\end{array}$ & $\begin{array}{l}\text { Volume } \\
\text { below } \\
\text { packer } \\
\text { (gal) }\end{array}$ & $\begin{array}{l}\text { Volume } \\
\text { purged } \\
\text { (gal) }\end{array}$ & $\begin{array}{c}\text { Total } \\
\text { volume } \\
\text { (gal) }\end{array}$ & $\begin{array}{l}\text { Percent- } \\
\text { age }\end{array}$ & $\begin{array}{l}\text { Ratio of volume } \\
\text { purged to } \\
\text { total volume }\end{array}$ \\
\hline (1) & (2) & (3) & (4) & $(5)$ & (6) & (7) & (8) & (9) & $(10)$ \\
\hline$\overline{\text { GS-1A }}$ & $\begin{array}{r}1-29-92 \\
4-16,17-92\end{array}$ & $\begin{array}{l}1-29-92 \\
4-17-92\end{array}$ & $\begin{array}{l}258 \\
254\end{array}$ & $\begin{array}{l}22.5 \\
77.7\end{array}$ & $\begin{array}{l}235 \\
176\end{array}$ & $\begin{array}{l}21.2 \\
58.2\end{array}$ & $\begin{array}{l}22.5 \\
77.7\end{array}$ & $\begin{array}{l}94 \\
75\end{array}$ & $\begin{array}{r}0.9: 1.0 \\
.7: 1.0\end{array}$ \\
\hline GS-1B & $\begin{array}{r}1-29-92 \\
1-30-92 \\
1-31-92 \\
2-3-92 \\
4-17,18-92\end{array}$ & $\begin{array}{r}2-3-92 \\
2-3-92 \\
2-3-92 \\
2-3-92 \\
4-18-92\end{array}$ & $\begin{array}{l}187 \\
187 \\
185 \\
185 \\
187\end{array}$ & $\begin{array}{r}10.7 \\
10.7 \\
8.6 \\
9.0 \\
11.0\end{array}$ & $\begin{array}{l}176 \\
176 \\
176 \\
176 \\
176\end{array}$ & $\begin{array}{r}9.0 \\
8.5 \\
2.6 \\
4.0 \\
75.0\end{array}$ & $\begin{array}{r}10.7 \\
10.7 \\
8.6 \\
9.0 \\
11.0\end{array}$ & $\begin{array}{r}84 \\
79 \\
30 \\
44 \\
682\end{array}$ & $\begin{array}{r}.8: 1.0 \\
.8: 1.0 \\
.3: 1.0 \\
.4: 1.0 \\
6.8: 1.0\end{array}$ \\
\hline GS-2 & $\begin{array}{l}1-28-92 \\
4-14-92\end{array}$ & $\begin{array}{l}1-28-92 \\
4-14-92\end{array}$ & $\begin{array}{l}251 \\
250\end{array}$ & $\begin{array}{l}-- \\
-\end{array}$ & $\begin{array}{l}-- \\
--\end{array}$ & $\begin{array}{r}132 \\
86\end{array}$ & $\begin{array}{l}251 \\
250\end{array}$ & $\begin{array}{l}53 \\
34\end{array}$ & $\begin{array}{l}.5: 1.0 \\
.3: 1.0\end{array}$ \\
\hline GS-3 & $\begin{array}{l}1-29-92 \\
4-15-92\end{array}$ & $\begin{array}{l}1-30-92 \\
4-15-92\end{array}$ & $\begin{array}{l}276 \\
276\end{array}$ & $\begin{array}{l}-- \\
--\end{array}$ & $\begin{array}{l}-- \\
--\end{array}$ & $\begin{array}{l}108 \\
118\end{array}$ & $\begin{array}{l}276 \\
276\end{array}$ & $\begin{array}{l}39 \\
43\end{array}$ & $\begin{array}{l}.4: 1.0 \\
.4: 1.0\end{array}$ \\
\hline GS-4A & $4-16-92$ & $4-16-92$ & 240 & 26.9 & 213 & 27.0 & 26.9 & 100 & $1.0: 1.0$ \\
\hline GS-4B & $\begin{array}{l}1-29-92 \\
1-31-92 \\
4-16-92\end{array}$ & $\begin{array}{l}1-31-92 \\
1-31-92 \\
4-16-92\end{array}$ & $\begin{array}{l}203 \\
203 \\
183\end{array}$ & $\begin{array}{l}3.7 \\
3.7 \\
2.9\end{array}$ & $\begin{array}{l}176 \\
176 \\
176\end{array}$ & $\begin{array}{r}3.2 \\
5.0 \\
11.0\end{array}$ & $\begin{array}{l}3.7 \\
3.7 \\
2.9\end{array}$ & $\begin{array}{r}86 \\
135 \\
379\end{array}$ & $\begin{array}{r}.9: 1.0 \\
1.4: 1.0 \\
3.8: 1.0\end{array}$ \\
\hline GS-4C & $\begin{array}{l}1-30-92 \\
4-17-92\end{array}$ & $\begin{array}{r}2-3-92 \\
4-18-92\end{array}$ & $\begin{array}{l}185 \\
185\end{array}$ & $\begin{array}{l}8.8 \\
8.7\end{array}$ & $\begin{array}{l}176 \\
176\end{array}$ & $\begin{array}{l}5.7 \\
5.0\end{array}$ & $\begin{array}{l}8.8 \\
8.7\end{array}$ & $\begin{array}{l}65 \\
57\end{array}$ & $\begin{array}{l}.6: 1.0 \\
.6: 1.0\end{array}$ \\
\hline GS-5 & $\begin{array}{l}1-27-92 \\
4-13-92\end{array}$ & $\begin{array}{l}1-27-92 \\
4-13-92\end{array}$ & $\begin{array}{l}237 \\
248\end{array}$ & $\begin{array}{l}-- \\
--\end{array}$ & - & $\begin{array}{l}54.6 \\
168\end{array}$ & $\begin{array}{l}237 \\
248\end{array}$ & $\begin{array}{l}23 \\
68\end{array}$ & $\begin{array}{l}.2: 1.0 \\
.7: 1.0\end{array}$ \\
\hline GS-6 & $\begin{array}{l}1-29-92 \\
4-15-92\end{array}$ & $\begin{array}{l}1-29-92 \\
4-15-92\end{array}$ & $\begin{array}{l}533 \\
536\end{array}$ & -- & -- & $\begin{array}{l}41.5 \\
75.2\end{array}$ & $\begin{array}{l}533 \\
536\end{array}$ & $\begin{array}{l}7.8 \\
14\end{array}$ & $\begin{array}{l}.1: 1.0 \\
.1: 1.0\end{array}$ \\
\hline GS-7 & $\begin{array}{l}1-28-92 \\
4-14-92\end{array}$ & $\begin{array}{l}1-28-92 \\
4-14-92\end{array}$ & $\begin{array}{l}247 \\
248\end{array}$ & $\ddot{-}$ & -- & $\begin{array}{l}250 \\
170\end{array}$ & $\begin{array}{l}247 \\
238\end{array}$ & $\begin{array}{r}101 \\
71\end{array}$ & $\begin{array}{r}1.0: 1.0 \\
.7: 1.0\end{array}$ \\
\hline GS-8A & $\begin{array}{l}1-29-92 \\
4-14-92\end{array}$ & $\begin{array}{r}1-31-92 \\
--\end{array}$ & $\begin{array}{l}190 \\
243\end{array}$ & $\begin{array}{l}7.9 \\
--\end{array}$ & $\begin{array}{r}182 \\
--\end{array}$ & $\begin{array}{l}118 \\
199\end{array}$ & $243^{7.9}$ & $\begin{array}{r}1,494 \\
82\end{array}$ & $\begin{array}{r}15.0: 1.0 \\
.8: 1.0\end{array}$ \\
\hline GS-8B & $\begin{array}{l}1-29-92 \\
4-17-92\end{array}$ & 4-17-92 & $\begin{array}{l}189 \\
234\end{array}$ & $\begin{array}{l}7.2 \\
--\end{array}$ & $\begin{array}{r}182 \\
--\end{array}$ & $\begin{array}{r}4.0 \\
35.6\end{array}$ & $2^{7.2}$ & $\begin{array}{l}56 \\
15\end{array}$ & $\begin{array}{l}.6: 1.0 \\
.2: 1.0\end{array}$ \\
\hline
\end{tabular}


APPENDIX 4. Hydraulic test data from U.S. Geological Survey monitoring wells GS-1 through GS-8 at Penn Mine site

Water-level drawdown and recovery data collected from boreholes during the water-quality sampling in April 1992 are presented graphically on the following pages. Where available, recovery data are presented, in plots of residual drawdown versus the logarithm of the time ratio [(time versus pump start)/(time since shutdown)]. Where recovery data were not collected (wells GS-5, $-6,-7$, and $-8 \mathrm{~A}$ ), drawdown data are shown, in plots of drawdown versus the logarithm of time. "Q" signifies the pumping rate and $\mathrm{gal} / \mathrm{min}$ is the abbreviated form for gallon per minute.
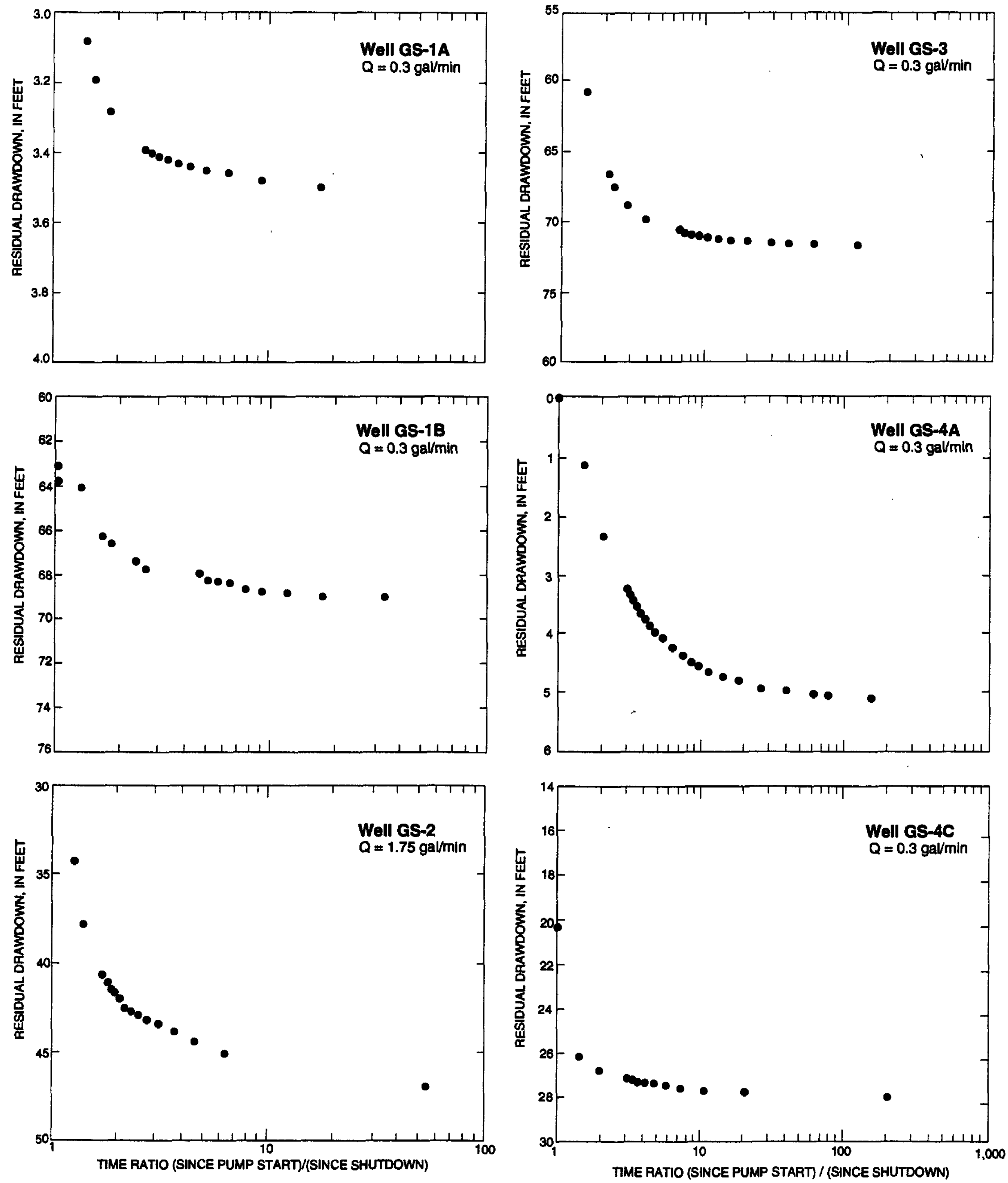
APPENDIX 4. Hydraulic test data from U.S. Geological Survey monitoring wells GS-1 through GS-8 at Penn Mine site-Continued
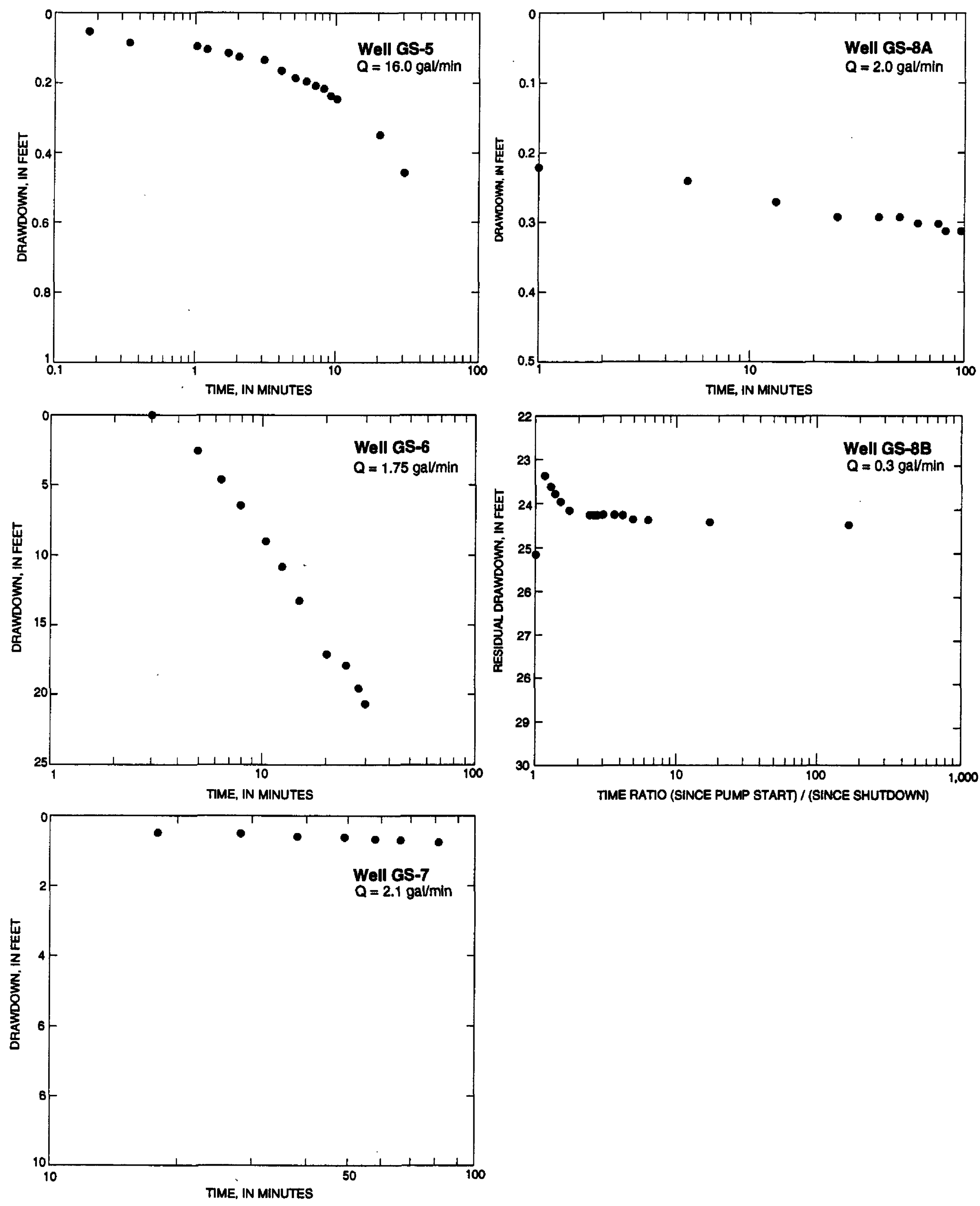